Portland State University

PDXScholar

Fall 1-3-2013

\title{
English Loan Words in Japanese: Exploring Comprehension and Register
}

Naoko Horikawa

Portland State University

Follow this and additional works at: https://pdxscholar.library.pdx.edu/open_access_etds

Part of the Applied Linguistics Commons, Bilingual, Multilingual, and Multicultural Education Commons, and the First and Second Language Acquisition Commons Let us know how access to this document benefits you.

\section{Recommended Citation}

Horikawa, Naoko, "English Loan Words in Japanese: Exploring Comprehension and Register" (2013). Dissertations and Theses. Paper 913.

https://doi.org/10.15760/etd.913

This Thesis is brought to you for free and open access. It has been accepted for inclusion in Dissertations and Theses by an authorized administrator of PDXScholar. Please contact us if we can make this document more accessible: pdxscholar@pdx.edu. 
English Loan Words in Japanese:

Exploring Comprehension and Register

by

Naoko Horikawa

A thesis submitted in partial fulfillment of the requirements for the degree of

Masters of Arts

in

Teaching English to Speakers of Other Languages

Thesis Committee:

Susan Conrad, Chair

Kimberley Brown

Suwako Watanabe

Portland State University

2012 


\begin{abstract}
English loan words (ELWs) have become a considerable part of the contemporary Japanese vocabulary. Meanwhile, it has been shown that there are individual differences in the rate of ELW comprehension. Among the factors for low comprehension is age; people over 60 years old have been shown to comprehend fewer ELWs than the overall age group. As Japan is expected to soon enter the era of an aging society, the issue of ELW comprehension is likely to present serious social and personal problems.

The purpose of this study was to identify the current state of frequently used ELWs in contemporary written Japanese, with particular attention to their frequencies, linguistic features, and comprehension rates by people over 60 years old. In order to identify the mediums that are likely to be problematic, three registers were examined: government white papers, books, and internet texts.

The study found that the three registers differ in their overall frequencies of ELWs and distributions of the semantic categories, while the distributions of the types of borrowing are similar. It also found that ELWs in certain semantic categories have lower comprehension rates than other categories. Registers that regularly contain lowcomprehension ELWs are likely to pose problems for readers over 60 years old.
\end{abstract}




\section{Table of Contents}

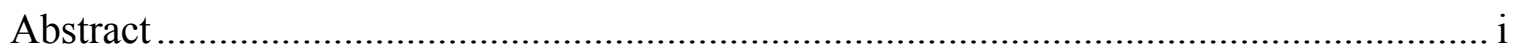

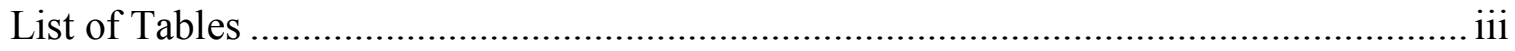

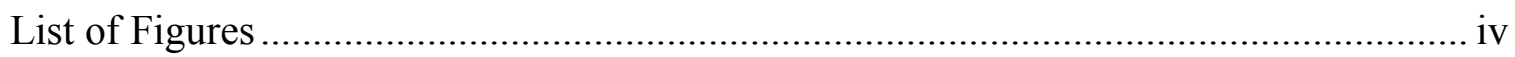

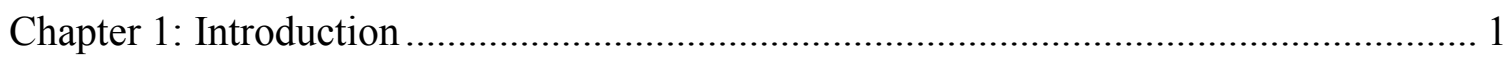

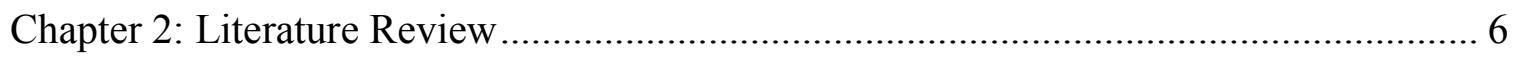

Loan Words in Japanese: Historical Context...................................................... 6

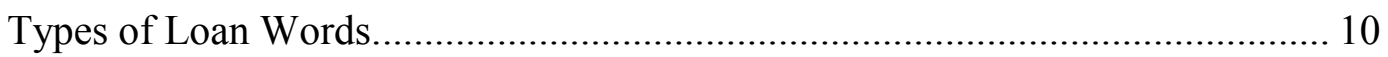

Characteristics of ELWs in Japanese ............................................................ 12

Perception and Comprehension .................................................................... 18

Considering ELWs in Registers..................................................................... 20

Literature Review Summary and Research Questions........................................ 21

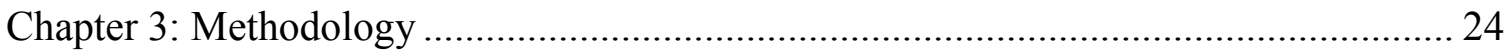

Background: The BCCWJ and the Monitor Data ……………………................ 24

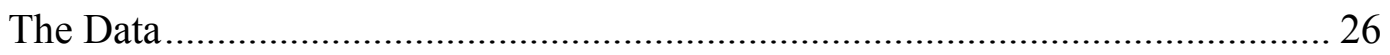

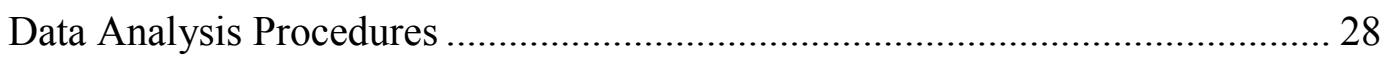

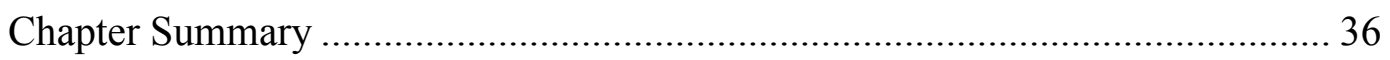

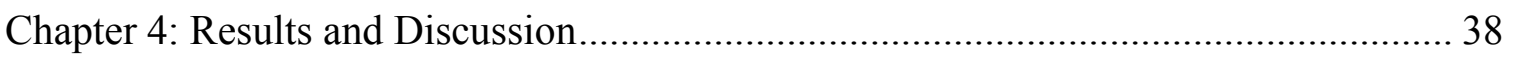

Katakana Words and High-frequency ELWs ..................................................... 38

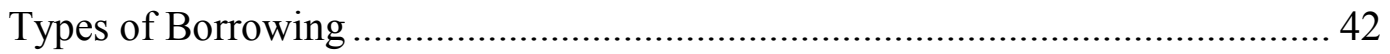

Semantic Categories of the High-Frequency ELWs .............................................. 46

Comprehension Rates of the High-frequency ELWs........................................... 57

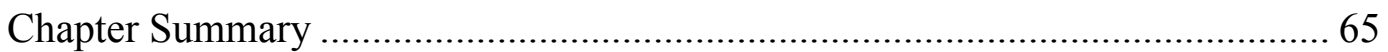

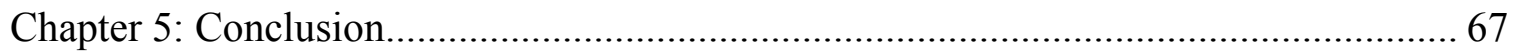

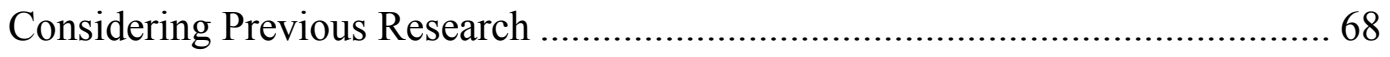

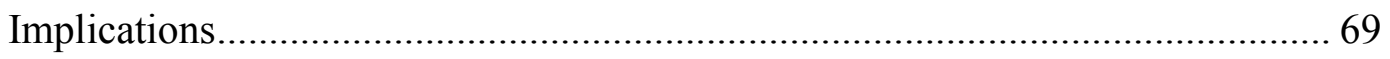

Limitations to the Study and Suggestions for Future Research............................ 72

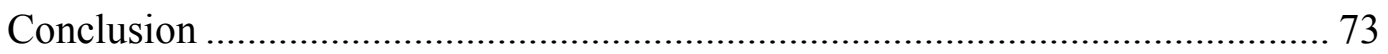

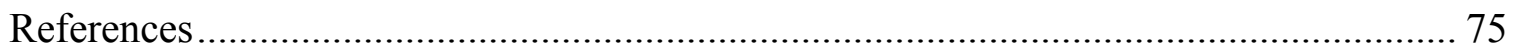

Appendix A: High-frequency ELWs .............................................. 79

Appendix B: High-frequency ELWs by Semantic Categories .........................86 


\section{List of Tables}

Table 1: Examples of monolingual and hybrid compound words based on Irwin's

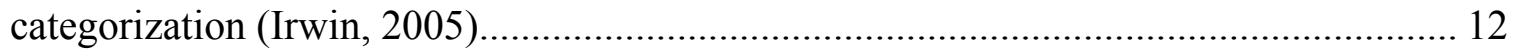

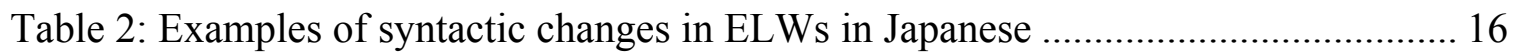

Table 3: The results of Language Attitude and Pervasion Survey: Five most and least

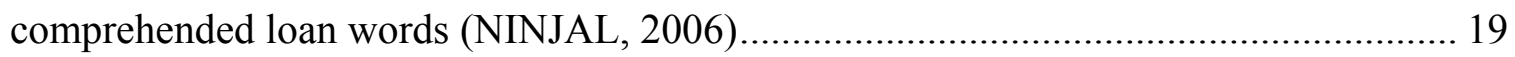

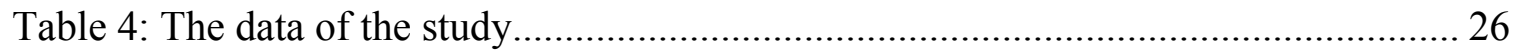

Table 5: Topic categories in white papers, books, and internet texts ............................ 27

Table 6: Diversity and frequency of katakana words and high-frequency ELWs ........... 39

Table 7: Distribution of high-frequency ELWs ................................................... 41

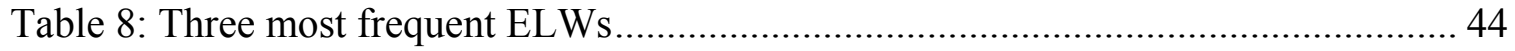

Table 9: Thirteen theme-based semantic categories, their operational definitions, and

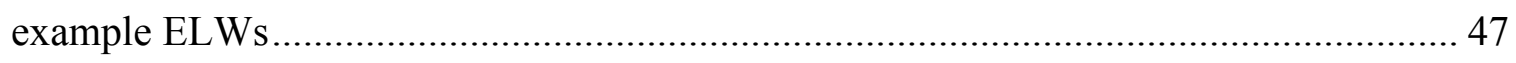

Table 10: Two non-theme-based semantic categories, their operational definitions, and

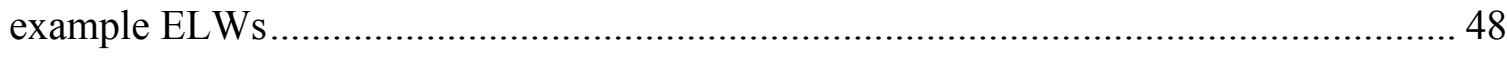

Table 11: Overall distribution of semantic categories in the order of frequency ............ 48

Table 12: Distribution of semantic categories per register ....................................... 49

Table 13: High-frequency ELWs Comprehension List based on Language Attitude and

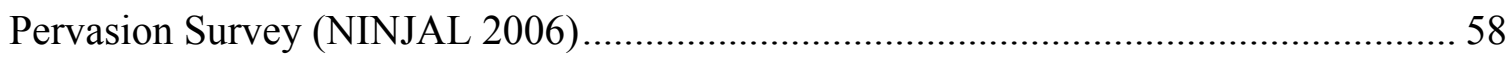

Table 14: High-frequency ELW comprehension list by the semantic category ............... 62

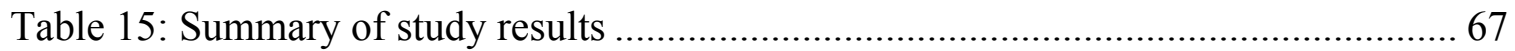




\section{List of Figures}

Figure 1: Official front page of the Japanese Prime Minister's webpage......................... 2

Figure 2: Store front of Marukawa Jeans Shop. ..................................................... 15

Figure 3: Example of modified corpus organized by the lexeme (White Paper)............. 30

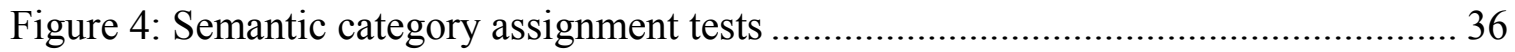

Figure 5: Frequencies of katakana words and high-frequency ELWs .......................... 39

Figure 6: TTR comparison of katakana words found in three registers ......................... 40

Figure 7: Proportions of the types of borrowing by register..................................... 43

Figure 8: Proportions of the types of borrowing in major semantic categories............... 51

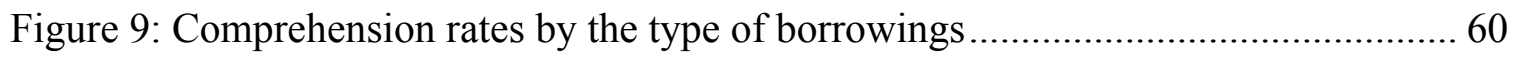

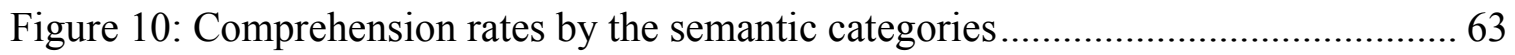

Figure 11: A flyer promoting online tax filing, found on a local bus in Tokyo ............... 70 


\section{Chapter 1}

\section{Introduction}

In recent years, a number of anecdotal accounts and studies have reported on the ubiquitous nature of English loan words (ELWs) in contemporary Japanese. Particularly, their rapid growth, pervasiveness, creativity, and "intimate incorporation" (Kachru \& Nelson, 2006, p. 172) into Japanese are often the primary interests of the authors (Daulton, 2008; Kachru \& Nelson, 2006; Kay, 1995; Loveday, 1996). These reports are also true in my own personal experiences as a native speaker of Japanese. Every time I visited Japan in the past eight years, I encountered ELWs that I had never expected to see in Japanese. It seems that ELWs are constantly expanding not only in numbers, but also in the contexts and ways in which they are used. As a student of linguistics with great interest in language contact, this phenomenon to me has been nothing but a source of fascination. However, it has also caused problems when communicating with my elderly family members who not only have difficulty understanding the meanings of certain loan words but also embracing the new life styles that these loan words represent, such as blog (,burogu’ブログ), download (,daun roodo’ダウンロード), or to google (,guuguru’グ

ーグル) something. They almost seem resentful that the younger generation is using words that they do not understand.

Figure 1, a snapshot of the official government website, shows just how much ELWs have become common in Japanese (Prime Minister of Japan and His Cabinet, 2011). On this page alone, twelve English-based words written in Japanese script are found: サイトマップ „,site map’, リンク ‘link', トピックス „topics’, ステップ „step’, インフルエンザ,,influenza', ブログ „,blog, チーム „team’, スタート ,start', トップ 
‘top', セールス ,sales’, and メール „,mail’. In addition, there are English phrases and abbreviations written in the Roman alphabet: „Prime Minister of Japan and His Cabinet', „FAQ', 'PDF', 'RSS', 'English', '[Kan-]Full Blog.'

Figure 1: Official front page of the Japanese Prime Minister's webpage

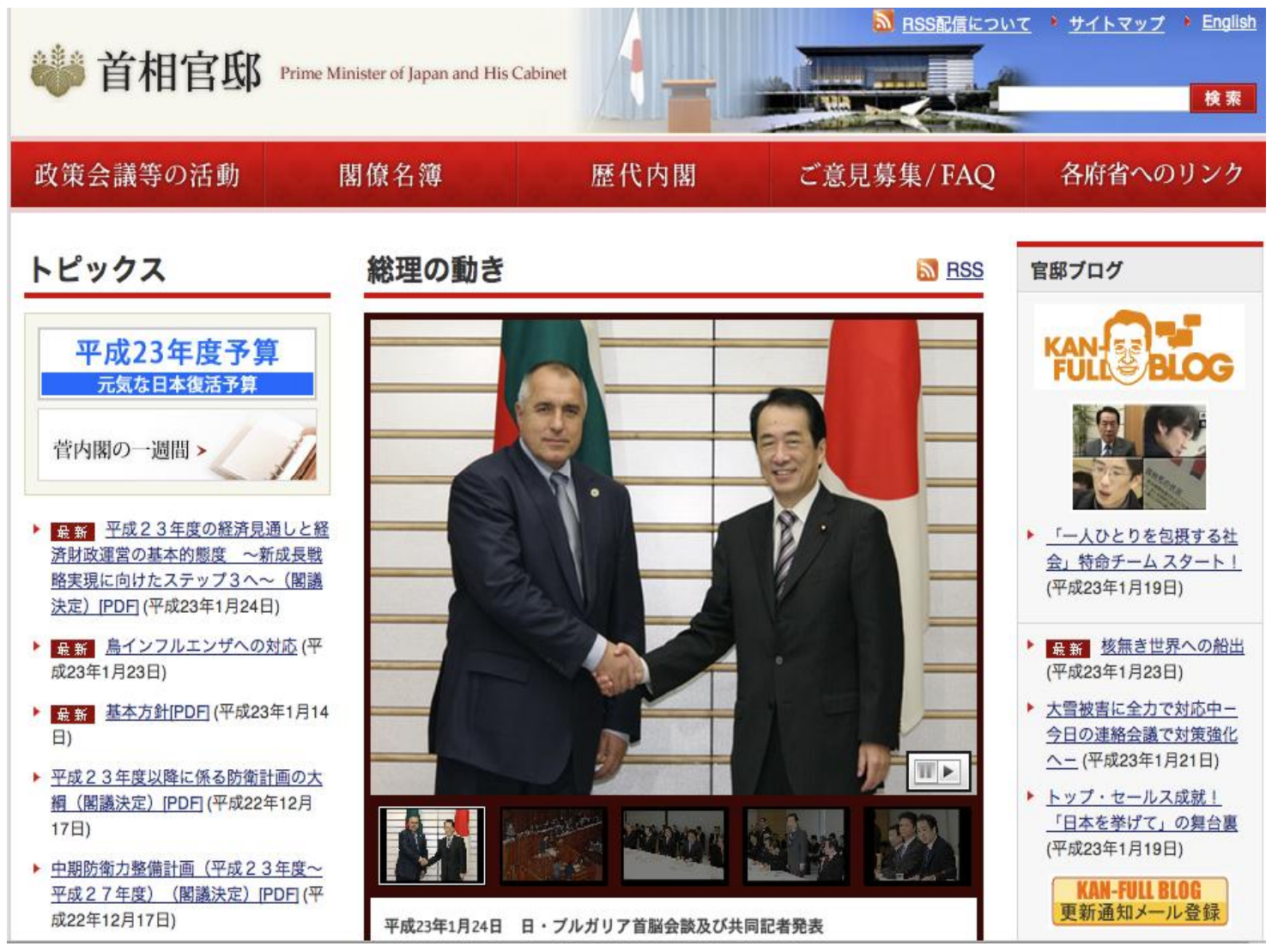

According to the Japanese National Language Research Institute, ELWs make up eight percent of the total Japanese vocabulary and 94\% of all Western loan words, which also include Dutch, Portuguese, and German (as cited in Stanlaw, 2004). Furthermore, Sanseidou, one of Japan's leading dictionary publishers, recently released a new edition of the Concise Katakana-Word Dictionary (Sanseido, 2010), a compilation of 48,100 loan words, most of which are of English origin.

Despite the high number of loan words, there are considerable individual 
differences in the comprehension levels of loan words. According to the study conducted by Nippon Hoso Kyokai (Japan Broadcasting Corporation), as cited in Daulton (2008), one of the backgrounds that influence the comprehension of loan words is age. Compared to more traditional loan words, older people were less familiar with "radically innovative loan words" (p. 87), suggesting that loan words are actively incorporated and modified by a younger generation.

Another aspect of loan word knowledge is people's attitude and perceptions towards them. Myers-Scotton (2006) suggested that attitude towards a particular language or word correlates with the rate of acquisition and usage. Also, according to two surveys conducted by the National Institute of Japanese Language and Linguistics (NINJAL, 2006), Japanese people over 60 years old were found to have lower approval rates for loan words and to comprehend fewer of them in comparison to the overall population.

In sum, although ELWs undoubtedly constitute a considerable part of the contemporary Japanese vocabulary, some people, especially those who are 60 years old or above, do not seem to approve or understand them, which could pose communication problems. Those without sufficient understanding of common loan words are not likely to receive the same amount and quality of information as people who comprehend them would. In addition, low comprehension of ELWs could impair their abilities to function in domains in which ELWs are frequently used. As the number of the elderly is rapidly increasing in Japan, their low comprehension of loan words is likely to result in serious societal and personal problems. 
However, not all ELWs appear equally in the same kinds of texts, and the chances of encountering ELWs are higher for certain kinds of texts than they are for others. Studies have been conducted to investigate the loan word distributions among different registers, such as newspapers and magazines (Shibatani, 1990; Tanaka, 2007; Kiryuu, 2007); however, the mediums through which information is disseminated today are much more diverse, largely due to the advancements in computer technology. Therefore, in order to gain further understanding of where communication problems might occur due to low comprehension of ELWs, it is necessary to consider different mediums of communication that include both traditional and contemporary platforms.

The present study uses a corpus linguistic approach to investigate ELWs in three registers: government-issued reports, books, and internet texts. More specifically, it identifies the overall ELW frequencies and the attributes of those that occur frequently in each register, allowing register characteristics with respect to ELWs to emerge. The study also identifies the extent to which people over 60 years old comprehend common ELWs in the three registers, drawing comparison among the registers with regard to ELW comprehension. It is my hope that the findings of this study will contribute to our understanding of the current state of ELW use in Japanese, and provide useful information necessary to identify disadvantages that those with low ELW comprehension might be experiencing.

There are five chapters in this study. Chapter 2 reviews previous studies concerning ELWs in Japanese and introduces the research questions of the study, establishing the scope of the present study. Chapter 3 introduces the data and the analysis procedures of the study, followed by Chapter 4, which presents the analysis results and 
their implications. Finally, Chapter 5 synthesizes the literature review, research questions, and the study findings and discusses limitations of the study, and then concludes the study. 


\section{Chapter 2}

\section{Literature Review}

The following literature review is divided into four sections; the first section looks at the historical background of Japan's language contacts and the current status of English loan words (ELWs). The following section provides detailed characteristics of ELWs. The third section reviews studies on the perceptions of loan words by the Japanese people and their familiarity with them, with special attention to those over 60 years old. Finally, the fourth section looks at loan words from a register perspective, drawing on the general discussion of registers and previous studies concerning loan words in a particular register. The chapter concludes with the research questions for this study.

\section{Loan Words in Japanese: Historical Context}

In order to gain an overall picture of loan words in Japanese, it is important to consider their historical background. Long before European languages were introduced, China was the single most prominent influence on Japanese culture and language (Miller, 1967, 1986; Loveday, 1996). China's political system, culture, and language were introduced to Japan, often by way of Korea, and were incorporated by the early Japanese powers during the fifth and the sixth centuries, A.D. (Miller, 1967; Inaga \& Takemori, 1997). One of the major consequences of this contact was the introduction of the written language and the mass importation of Chinese characters, as Japan had not developed its own orthography (Loveday, 1996; Inaga \& Takemori, 1997).

By the eighth century, Chinese had gained ,high second language' status and was used in various formal domains in Japanese society, such as law, academics, and religion 
(Loveday, 1996). However, as the Japanese developed their own scripts in addition to inventing a system for reading and writing Chinese characters based on the Japanese grammar and vocabulary, Chinese was no longer a subject of second language learning but was dissected and imported into Japanese itself as Sino-Japanese (Loveday, 1996; Irwin, 2005). For instance, words that did not exist in native Japanese, such as political terminologies, Buddhist concepts, and objects from the continent, were acquired through Chinese orthography with the pronunciation relatively faithful to the original language. For example, the native Japanese word for ,mountain' is yama, which is 山 in written Chinese. Since the word had already existed in spoken Japanese, only the written form of the word was incorporated, but not the Chinese sound for 山. However, for words that did exist in Japanese, either the Chinese translation was added as an alternative word choice, or only the Chinese character for the word was employed to express the original Japanese word. Thus, there are two possible choices for the word ,mountain range' in Japanese: one is native Japanese word yamanami, which comes from yama (,mountain') and nami (,range') and the other is sanmyaku, which is a direct loan word from Chinese („,脈') (Yan, 1994). The two words, however, slightly differ in their subtle nuances and appear in different contexts. While the Japanese word yamanami typically refers to a smaller range of mountains and connotes a softer impression than the Sino-Japanese sanmyaku, which is always used as the official name of the mountain range (i.e. Hidaka sanmyaku (日高山脈), ,the Hidaka Mountains’).

Chinese influences, whether orthographical or lexical, are so deeply embedded in today's Japanese that they are considered inseparable elements of the language (Miller, 
1967). The Chinese character remains one of the three scripts of Japanese orthography, and words that originate from Chinese comprise $49 \%$ of the Japanese vocabulary (Kindaichi, 2002). Thus, by the time the importation of ELWs began, the Japanese had already experienced a major language contact, which helped establish a unique method of incorporating foreign vocabulary.

Japan's first major contact with the West dates back to the $16^{\text {th }}$ century when Portuguese and Spanish missionaries and trade merchants arrived in Japan. However, the impact of the contact was limited at that time, as there was little or no centralized promotion of the outside world due to long lasting provincial wars and isolationist policies during the Edo period (1600-1868) (Miller, 1967; Inagaki \& Takemori, 1997; Loveday, 1996).

With the Meiji Reform in the late $19^{\text {th }}$ century, however, westernization of the country was promoted at a rapid rate. The government played a leading role by sending delegates to European countries and rigorously importing Western literature, politics, technology, science, and culture. European culture and language were considered to be the symbol of modernization and sophistication (Loveday, 2008). During this period, there were several major European languages from which words were imported: English, French, German, Italian, Portuguese, Spanish, Dutch, and Russian. In addition to direct loan words, creation of new Japanese-based words for the newly introduced concepts and vocabulary was undertaken. For example, the importation of the concept democracy resulted in two new words entering the Japanese vocabulary: minshushugi (民主主義), which is a calque using the Chinese orthography, and a phonologically modified English loan word demokurashii (デモクラシー) (Loveday, 1996). 
The next major wave of contact with the West came after World War II. In this period, importation of Western values and culture, most directly from the U.S., was conditioned both by the Allied occupation between 1945 and 1952, and the public's social motivation to embrace and become part of the Western world and its economic success (Loveday, 1996). With the economy booming in the 1980's and 1990's, overseas traveling and English learning gained greater popularity, resulting in more EnglishJapanese language contacts among ordinary people.

There was a common pattern for the importations of Chinese and European languages; when the government regarded the language and the culture of the donor language to be valuable and important for the country's future, a great deal of investment was made for a small group of elites to acquire the language (Loveday, 1996). These elites acquired the new language as a whole and used it bilingually, separating one language from the other. However, when the language eventually reached the public for its own use, it was reduced to smaller segments, usually at the lexical level, which were eventually digested to become part of the Japanese vocabulary.

The importation of Chinese, after a few revivals during the Edo period, seems to have come to an end at the moment, as we have not seen new Chinese loan words entering Japanese since. On the contrary, English seems to continue to be an active donor language, adding a significant number of loan words each year. Presently, ELWs make up eight percent of the total Japanese vocabulary and 94\% of all Western loan words, which also include Dutch, Portuguese, and German (Japanese National Language Research Institute, as cited in Stanlaw, 2004). Furthermore, Sanseidou, one of Japan's leading dictionary publishers, recently released a new edition of the Concise Katakana- 
Word Dictionary (Sanseido, 2010), a compilation of 48,100 foreign origin words, most of which are of English origin.

\section{Types of Loan Words}

On a broad level, loan words can be divided into two major groups: cultural borrowing and core borrowing (Myer-Scotton, 2006). According to Myer-Scotton, cultural borrowing refers to lexical borrowings "that fill gaps in the recipient language's store of words because they stand for objects or concepts new to the language's culture" (p. 212). Examples of cultural borrowing in Japanese include computer, fax, and many other technology-related words, as the concepts of these words were introduced along with the language. Core borrowing, on the other hand, refers to importation of a foreign word when the object or concept already exists in the recipient language, creating "duplicate elements that the recipient language already has in its word store" (MyerScotton, 2006, p. 215). Rabu (,love') and happii (,happy’) are examples of core borrowing from English to Japanese.

Furthermore, words can be borrowed directly or indirectly. A direct borrowing refers to situations where a donor word is received as it is by the host language, whereas indirect borrowing involves alterations of the donor word (Myer-Scotton, 2006). One of the most common indirect borrowings is calque, where the meaning of the donor word itself is borrowed, but the actual word that becomes part of the recipient language is its translation. The word democracy mentioned earlier is an example of cultural borrowing that involves both direct and indirect borrowing: 


\section{English: democracy}

Type of borrowing: Cultural, as the concept was new to Japanese

Direct borrowing: Demokurashii～デモクラシー

Indirect borrowing: minshushugi民主主義

When there is a duplicate word that refers to the same concept, differences in the context, the nuance of the word, and the attitude towards the donor or recipient language are involved in the selection. Love (,rabu’, ラブ), is an example of core direct borrowing, which competes against its Japanese equivalent ai (愛). To most Japanese speakers, the loan word $r a b u$ is common enough that they would comprehend the meaning. However, the two words are not always used in the same way. The English loan word rabu is typically used for romantic love as in rabu sutoorii (,love story') and rabu retaa (,love letter'), while the Japanese equivalent $a i$ has broader use. When there is no absolute difference in the context, the selection of the word involves the nuances and the intent of the speakers; they might want to sound Western-like by using rabu, or sound more formal by using ai. Attitudinal differences also likely influence the selection between the loan and the native word. On the other hand, a conservative view against foreign languages might restrict one's selection of a loan word, as Loveday (1996) noted:

A further attitude that has received little attention is the conception that the current extent of Western borrowings is leading to language „decline' or „infection' and is a sign that the Japanese have lost faith in their own linguistic creativity... (p. 208)

People that are less likely to approve of the increase of ELWs are older people who have 
established their repertoires of vocabulary and see less immediate need for loan words, or who even feel threatened by the rapid intake of foreign words.

\section{Characteristics of ELWs in Japanese}

As a result of the language contacts discussed above, the contemporary Japanese vocabulary is comprised of three major types of language sources: native-Japanese (NJ), Sino-Japanese (SJ) (words that derive from Chinese, but are now considered Japanese), and other foreign languages (FJ), most of which are English (Irwin, 2005). While all of these languages can form a complete word (i.e. yama [NJ], sanmyaku [SJ], demokurashii $[\mathrm{FJ}])$, many of them also form compound words. Irwin (2005) categorized the patterns of compound words into three types of monolingual compounds and six types of hybrid compounds. Table 1 provides examples of monolingual and hybrid compounds based on Irwin's categorization.

Table 1: Examples of monolingual and hybrid compound words based on Irwin's categorization (Irwin, 2005, p.123)

\begin{tabular}{|c|c|c|}
\hline & $\begin{array}{l}\text { Type of } \\
\text { compound }\end{array}$ & Examples \\
\hline \multirow[t]{3}{*}{ Monolingual } & NJ-NJ & yama-michi: 山道 (,mountain',+ path' $=$,mountain trail') \\
\hline & SJ-SJ & sei-mei 姓名 (,surname' +, given name’ =,full name') \\
\hline & FJ-FJ & $\begin{array}{l}\text { intaanetto-kafe インターネットカフェ }(, \text { internet' }+ \text {,café' }=\text { „,cyber } \\
\text { café') }\end{array}$ \\
\hline \multirow[t]{6}{*}{ Hybrid } & NJ-SJ & buta-niku 豚肉 (,pig',+ ,meat' $=$,pork') \\
\hline & NJ-FJ & ichigo-soda 芼ソーダ (,strawberry’ +, ,soda' = ,strawberry soda') \\
\hline & SJ-NJ & ki chigai 気違い (,mind',+ ,discrepancy’ $=$, ,insanity') \\
\hline & SJ-FJ & dai seeru 大セール (,big' + ,sale’ = „,big sale’) \\
\hline & FJ-NJ & gomu-tebukuro ゴム手袋 (,gum’ + ,gloves' = ,rubber gloves') \\
\hline & FJ-SJ & $\begin{array}{l}\text { fasshon-kai フアッション界 (,fashion’ + ,domain’ = ,the fashion } \\
\text { industry' }\end{array}$ \\
\hline
\end{tabular}

Once incorporated into Japanese, English words undergo major and minor linguistic changes, similar to what happened with Chinese. These changes are often described in terms of the following areas: phonology, orthography, morphology, 
semantics, and syntax (Daulton, 2008; Kachru \& Nelson, 2006; Kay, 1995; Kowner \& Daliot-Bul, 2008; Stanlaw, 2004).

Phonological change. The phonological changes for ELWs occur in accordance with native Japanese phonology (Kay, 1995; Kubozono, 2005). The general rule is that when an English sound has no equivalence in the Japanese phonetic inventory, the Japanese sound that is perceptually closest to its English equivalent replaces it. With respect to consonants, Tsujimura (1996) observed that there were four typical sound substitutions in English loan words: /f/, /v/, / / /, and /ð/are substituted by / $/ /, / \mathrm{b} /, / \mathrm{s} /$ and /z/, respectively. Another common area of change is syllable structure. The Japanese syllable system, often distinguished from English syllable structure as mora-timing (Kubozono, 1995), has a strong inclination to consonant-vowel (C-V) pairing, which is not always the case in English. Therefore, an English sound with no vowel ending is likely to change to a $\mathrm{C}-\mathrm{V}$ combination when entering Japanese (e.g. „,milk' is changed from $/ \mathrm{mikk} /$ to $/ \mathrm{mIruku} /$ ).

In sum, phonological changes are mostly predictable and rule-governed. It is through these predictable patterns that ELWs are phonologically made accessible to Japanese monolingual speakers.

Orthographical change. Instead of using the original form of the word in the Roman alphabet, which is known to an increasing number of Japanese speakers, loan words are usually written in katakana, one of the three character sets in Japanese writing (hiragana, katakana, and kanji). Katakana is employed exclusively to write words of foreign-origin (Akamatsu, 2006; Kubozono, 1995; Stanlaw, 2004). Hence, the ELW milk is written as ミルク in katakana, rather than みるく in hiragana. This orthographical 
change is largely influenced by the phonological changes discussed above. Katakana, similar to hiragana, consists of 71 characters that are phonetically relevant to syllables that exist in Japanese speech; for example, the letter ミ in the example above (ミルク) represents the syllable $/ \mathrm{mI} /$ and $ル$ represents $/ \mathrm{su} /$. Although an in-depth phonetic inventory indicates that the written form of words are not the same as the spoken form (Tsujimura, 1996; Yamane, 2001), katakana provides the reader with necessary information about how to say an ELW in the Japanese context. It also semiotically and symbolically marks all loan words as not Japanese, while simultaneously suggesting that they are now entering the Japanese language.

Occasionally, ELWs are written in Roman letters instead of katakana (Daulton, 2008; Stanlaw, 2004). In fact, the use of the Roman alphabet has become so common in Japan that Kess and Miyamoto (1999) stated that Japanese has a fourth script which is not formally recognized as part of the traditional orthographic system. Roman letters are omnipresent and used in a number of interesting ways to complement the appearance of hiragana, katakana, and kanji in printed text. This phenomenon is especially pervasive in advertisements where Western-words are used to attract customers (Baker \& Jones, 1998). As mentioned earlier, loan words, after being established as part of the Japanese vocabulary, are learned as katakana words and the knowledge of the original English spelling is not required. The question with re-Romanization of ELWs is whether the reader is able to configure the spelling of the English word, link it to its equivalent in katakana, and understand the meaning. If this process is incomplete, it can potentially cause comprehension problems. For example, ジーンズ (,jeans') is a common loan word for many Japanese people who are now accustomed to wearing denim trousers. However, 
without the knowledge of the English spelling of the word, one might not be able to read the sign „Jeans Shop' (Figure 2).

Figure 2: Store front of Marukawa Jeans Shop. (Image retrieved from google.com)

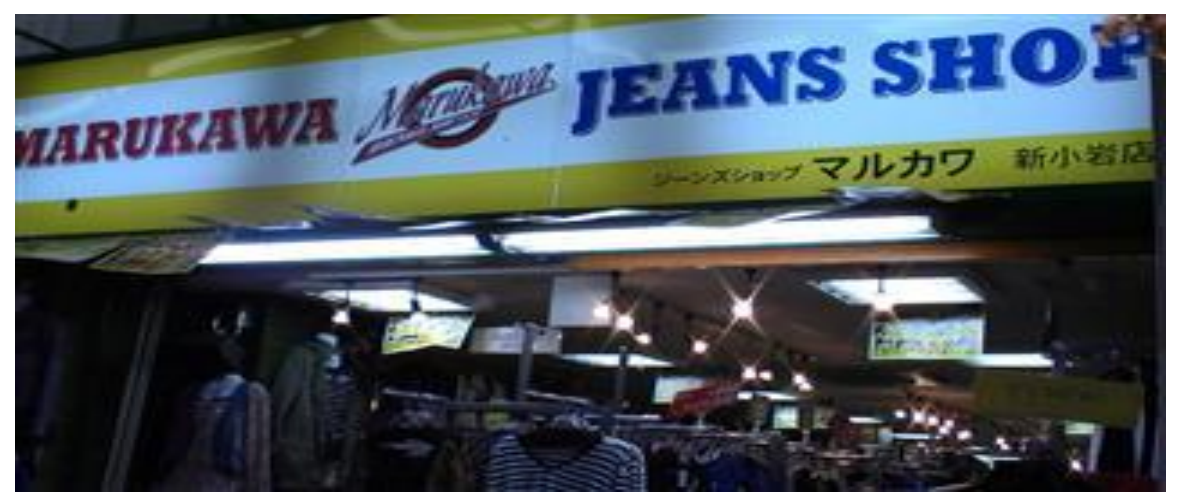

Morphological change. The most typical morphological change of ELWs in Japanese is ,clipping', the shortening of the original word by omitting one or more syllables. Kay (1995) used the word accelerator to show how this was back-clipped to become akuseru (,accel[erator]'). Shortened words are sometimes used in compound words. For example, personal computer, after being phonologically altered to /pa-a-sona-ru kon-pyu-ta-a/ (パーソナルコンピューター), is further shortened to /pasokon/ (パ ソコン). Other examples of clipping include: depaato (,department [store]'), suupaa (,super[market]'), hebimeta (,heavy meta[1]'), and superu (,spell[ing]').

It is also common for ELWs in Japanese to become part of English-Japanese hybrid compound words. For example, the Japanese word ha (,tooth') and an ELW burashi (,brush’) are combined and make up ha-burashi (,toothbrush’). Clipped loan words can also be part of compound words. For example, the word depa-chika, which refers to the basement level of a Japanese department store where delicatessen shops are typically located, consists of the following elements: 1) depa, a shortened version of 
back-clipped loan word depaato (,depart[ment store]') and 2) a Japanese word, chika (,underground').

Syntactic change. Syntactic change of a loan word is typically discussed with respect to the creation of verbs, adjectives, or adverbs through the addition of Japanese affixes. Loveday (1996) described the initial process of this change: “...in most cases the Japanese treat loans as uninflected nouns or bound bases that do not belong to a word class but which are potentially convertible to any class by means of suffixation..." (p. 138). Nouns constitute $90 \%$ of English loan words, followed by adjectives and other parts of speech (Daulton, 2008). Japanese particles, such as $n a$ and $n i$, and the verb suru (,to do') are often used as suffixation devices to transform loan words into adjectives, adverbs, and verbs, as shown in Table 2.

Table 2: Examples of syntactic changes in ELWs in Japanese

\begin{tabular}{|c|c|c|c|c|}
\hline English & As a loan word & Affix & Part of speech & Example \\
\hline \multirow[t]{2}{*}{$\begin{array}{l}\text { logical } \\
\text { (adjective) }\end{array}$} & \multirow[t]{2}{*}{$\begin{array}{l}\text { rojikaru } \\
\text { ロジカル }\end{array}$} & -na (particle) & $\begin{array}{l}\text { rojikaru-na } \\
\text { (adjective) }\end{array}$ & $\begin{array}{l}\text { Kare wa rojikaru-na hito } \\
d a \\
\text { (,He is a logical person') }\end{array}$ \\
\hline & & -ni (particle) & $\begin{array}{l}\text { rojikaru-ni } \\
\text { (adverb) }\end{array}$ & $\begin{array}{l}\text { Kare wa rojikaru-ni mono } \\
\text { wo kangaeru } \\
\text { (,He thinks logically') }\end{array}$ \\
\hline \multirow[t]{2}{*}{$\begin{array}{l}\text { exciting } \\
\text { (gerund) }\end{array}$} & \multirow{2}{*}{$\begin{array}{l}\text { ekisaitingu } \\
\text { エキサイテイ } \\
\text { ング }\end{array}$} & -na (particle) & $\begin{array}{l}\text { ekisaitingu-na } \\
\text { (adjective) }\end{array}$ & $\begin{array}{l}\text { Ekisaitingu-na tatakai } \\
\text { (,An exciting battle’) }\end{array}$ \\
\hline & & -ni (particle) & $\begin{array}{l}\text { ekisaitingu-ni } \\
\text { (adverb) }\end{array}$ & $\begin{array}{l}\text { Ekisaitingu-ni ikiru } \\
\text { (,To live excitingly’) }\end{array}$ \\
\hline $\begin{array}{l}\text { enjoy } \\
\text { (verb) }\end{array}$ & $\begin{array}{l}\text { enjoi } \\
\text { エンジョイ }\end{array}$ & -suru (verb) & $\begin{array}{l}\text { enjoi-suru } \\
\text { (verb) }\end{array}$ & $\begin{array}{l}\text { Dokushin seikatsu wo } \\
\text { enjoi-suru } \\
\text { (,To enjoy single life’) }\end{array}$ \\
\hline \multirow[t]{2}{*}{$\begin{array}{l}\text { shopping } \\
\text { (gerund) }\end{array}$} & \multirow[t]{2}{*}{$\begin{array}{l}\text { shoppingu } \\
\text { ショッピング }\end{array}$} & -suru (verb) & $\begin{array}{l}\text { shoppingu-suru } \\
\text { (verb) }\end{array}$ & $\begin{array}{l}\text { Shoppingu-suru } \\
\text { (,,To do some shopping') }\end{array}$ \\
\hline & & $\begin{array}{l}\text {-chuudoku } \\
\text { (noun: ,addiction') }\end{array}$ & $\begin{array}{l}\text { shoppingu- } \\
\text { chuudoku } \\
\text { (compound } \\
\text { noun) }\end{array}$ & $\begin{array}{l}\text { Shoppingu-chuudoku } \\
\text { (,Shopping addiction) }\end{array}$ \\
\hline
\end{tabular}


Semantic change. Finally, semantic change refers to cases where the meaning of a loan word in the Japanese context differs from the word's original meaning in the English context. For example, the word about as an adjective in English would typically mean something is moving around as in ,he was up and about.' However, as a loan word in Japanese, abauto (about) is used as a descriptive word for someone that is not detailoriented as in ,kare wa abauto na hito desu' ("he is an ,about' person"=he is not a detailoriented person). Although not all loan words undergo this change (Hogan, 2003), there seems to be a substantial number of such occurrences. Stanlaw (2004), in his discussion on the two types of loan words, wrote:

...[words] imported from English include such everyday items as terebi for „television’, tabako (,tobacco’) for cigarettes, as well as myriads of baseball terms (e.g. hoomu ran „home run' or sutoraiku 'strike'); many of which reflect the importation of related aspects of Western culture. In addition, however, many other items are uniquely Japanese in their provenance, and might more accurately be regarded as made-in-Japan creations. This domestically-created Japanese English vocabulary include kyanpingu kaa (camping car for recreational vehicles), raibu hausu (live house for coffee shops or jazz clubs with live music), or afutaa kea (after care for product maintenance). (Stanlaw, 2004, pp. 11-12) As one can imagine, semantic change in ELWs can cause great confusion to those who are acquiring English, Japanese, and those who speak both languages, as they are required to reconfigure their knowledge of the words. 


\section{Perception and Comprehension}

As mentioned earlier, the individual differences in English loan word comprehension and attitude towards them are likely influenced by multiple factors, including age. Concerned that the pervasiveness of loan words was causing comprehension problems among the Japanese public, the National Institute for Japanese Language and Linguistics (NINJAL) conducted two surveys to assess the public's attitude towards and comprehension levels of ELWs (NINJAL, 2006).

The first survey, Gairaigo ni kansuru ishiki chousa (NINJAL 2004), which investigated the respondents' attitude towards loan words, was distributed nationwide to a total of 4,500 people over the age of 15 in 2003. Based on the survey, NINJAL found that approximately $55 \%$ of the overall respondents were either "not in favor of the increase" or "more or less not in favor of the increase" of loan words (Aizawa, 2007). Particularly, the percentage of people 60 and older who were not in favor of loan words was above $60 \%$. Some of the common concerns against the invasion of loan words were that they might cause communication problems depending on the interlocutor $(46.7 \%)$ and misunderstanding of the meaning $(37.2 \%)$, that the tradition of Japanese language is ruined $(33.3 \%)$, and that it is difficult to read and remember loan words $(27.4 \%)$.

The other survey, Gairaigo teichakudo chousa (NINJAL 2006), which was concerned with the respondents' familiarities with loan words, were distributed to a total of 2,861 people over 16 years old between the years 2002 and 2004. For this survey, the researchers selected approximately 300 loan words based on the following two criteria: the loan words are commonly used in public materials, such as newspapers, governmental-issued papers, and local newsletters, but are unlikely to be widely 
understood by people. In addition to these common-yet-unlikely-understood loan words, approximately 100 common-and-likely-understood loan words were included in the survey for comparison. Each respondent was presented with 15-30 words, and asked the following questions about them:

1. Have you seen or heard of this word? (yes/no)

2. If ,yes', do you understand the meaning of the word? (yes/somewhat yes/no)

3. If ,yes' or ,somewhat yes', have you used this word yourself? (yes/no)

The percentage of those who answered ,yes' was identified for each target loan word, as illustrated in Table 3. The percentage of respondents who comprehended the selected words was consistently lower for the age group over 60 years old, with an average of $13 \%$ difference.

Table 3: The results of Language Attitude and Pervasion Survey: Five most and least comprehended loan words (NINJAL, 2006)

\begin{tabular}{|l|l|l|l|l|l|l|}
\hline \multirow{2}{*}{} & \multicolumn{3}{|c|}{ Overall (\%) } & \multicolumn{3}{c|}{ Over 60 years old (\%) } \\
\cline { 2 - 7 } & Recog. & Compr. & Usag. & Recog. & Compr. & Usag. \\
\hline ストレス (stress) & 97.4 & $\mathbf{9 2 . 6}$ & 90.6 & 94.1 & $\mathbf{8 2 . 9}$ & 80.2 \\
\hline トラブル (trouble) & 96.2 & $\mathbf{9 2 . 3}$ & 86.4 & 89.2 & $\mathbf{8 1 . 1}$ & 70.7 \\
\hline プライバシー(privacy) & 97.1 & $\mathbf{9 1 . 9}$ & 87.6 & 91.6 & $\mathbf{8 1 . 7}$ & 76.3 \\
\hline リストラ(restructure) & 97.8 & $\mathbf{9 1 . 8}$ & 79.8 & 93.2 & $\mathbf{8 0 . 6}$ & 66 \\
\hline リサイクル (recycle) & 97.1 & $\mathbf{9 1 . 1}$ & 87 & 94.3 & $\mathbf{8 2 . 8}$ & 77 \\
\hline $\begin{array}{l}\text { アドミッション・オフィス } \\
\text { (admission office) }\end{array}$ & 7.2 & $\mathbf{2 . 4}$ & 0.9 & 1.8 & $\mathbf{0 . 4}$ & 0.2 \\
\hline オーセンティシティ(authenticity) & 4.3 & $\mathbf{2 . 2}$ & 1 & 1.8 & $\mathbf{1 . 1}$ & 0.4 \\
\hline トリアージ (triage) & 4 & $\mathbf{2}$ & 1.1 & 2.1 & $\mathbf{0 . 2}$ & 0 \\
\hline フィランソロピー(philanthropy) & 5 & $\mathbf{1 . 9}$ & 0.7 & 4.1 & $\mathbf{1 . 7}$ & 0.9 \\
\hline キュレーター (curator) & 4.9 & $\mathbf{1 . 5}$ & 0.5 & 1.6 & $\mathbf{0 . 2}$ & 0 \\
\hline
\end{tabular}

In sum, NINJAL found that people over 60 years old were less in favor of and comprehended loan words less compared to the overall age group (Aizawa, 2006). Based on these results, it seems clear that there is a mismatch between the preference and the phenomenon, especially for those over 60 years old; the use of loan words is growing 
despite the fact that many people do not approve and/or comprehend them. While NINJAL's survey findings shed light on this serious social issue, what is still left unclear is where and how frequently they are likely to encounter loan words that they do not understand.

\section{Considering ELWs in Registers}

One of the ways to investigate "where" people might encounter certain loan words is analyze the register in which loan words are frequently found. Studies in discourse analysis and corpus linguistics have shown that the context of use often influences linguistic features, including lexical choices (Biber, Conrad \& Leech, 2002; Biber \& Conrad, 2009). For example, in their discussion of features, Biber and Conrad (2009) demonstrated that the situational characteristics of classroom teaching (i.e. spoken, interactive, personal) resulted in relatively frequent use of certain linguistic features, such as pronouns, mental/desire verbs, and clause-initial and/but (p.65). In comparison, the situational characteristics of academic prose (i.e. written, no interaction between the author and the reader, carefully composed) resulted in the relatively frequent use of nouns and complex clause structures. This analysis methodology, which links the situational and linguistic characteristics to investigation of the language features, can be extended to loan word analysis, as some have done.

Tanaka (2007) looked at three registers (newspapers, government-issued white papers, and local newsletters) and reported that the types of frequently occurring loan words were representative of the content, which varied among registers. He found that local newsletters contained more loan words related to day-to-day activities (e.g. challenge, pool, gallery), while the government white papers included more loan words 
related to economy, business, and information (e.g. part-time, monitoring, initiative)

while newspapers contained more loan words related to sports, especially baseball and golf (e.g. solo, play off, birdie). Furthermore, he found that the highest rate of comprehension of frequent loan words occurred more in local newsletters than in white papers.

Topic area within register is another factor that has been shown to influence loan word frequencies. Kiryuu (2007), in her analysis of Japanese newspaper sections, found that section-specific loan words were most frequently found in sports, entertainment, science, home, and economy sections, while there were fewer section-specific loan words in the front page, third page, and the editorial section, which do not have explicit topics assigned for them.

Lexical choices are also influenced by communicative purposes. For example, advertising, whose communicative purpose is to tell the reader how attractive a product is, tends to use words that are unique and draw readers' attention. Therefore, it is common for Japanese advertisements to incorporate ELWs to ,enhance the attentiongrabbing potential of English, making it an effective tool in promotional strategies' (Daulton, 2008).

\section{Literature Review Summary and Research Questions}

In this chapter, I have provided background for the present study. In particular, I have provided the historical background of Japan's importation of foreign languages that led to the wide spread of ELWs in contemporary Japanese. I have also reviewed the linguistic characteristics of ELWs and the types of lexical borrowing, which provided the reader with a general sense of the processes that ELWs undergo when entering Japanese. 
I have also presented previous studies concerning comprehension of ELWs, in which people over 60 years old have been shown to be less in favor of and familiar with ELWs. Finally, I have reviewed register variations and lexical choices, and presented multiple factors that likely influence the use of ELWs.

Previous studies have provided some basis for linking context of use, age, and rates of comprehension to better understand the multiple dimensions of loan words in Japanese. However, so far the studies have been limited to public materials, such as newspapers and government-issued white papers. Although these materials are one source of public information, they rarely cover personal issues and interests, as do some other registers, such as general books and internet texts. The Internet especially has undoubtedly become a significant part of the contemporary lifestyle, and texts produced on the Internet seem likely to contain different kinds of loan words that may be understood differently. Therefore, in order to gain a comprehensive picture of the problem that people, especially those over 60 years old, experience in comprehending ELWs, an investigation of a wide range of mediums of communications, including the traditional and contemporary, is needed.

In this study, in order to gain a further understanding of the current state of ELWs that are poorly understood by people over 60 years old so as to identify the most problematic medium, I investigated the following three written registers: governmentissued white papers, books, and internet texts. The specific research questions of the study are as follows: 


\section{Research Question 1:}

For each of three registers-government-issued reports, books, and internet texts-how do the following compare?

- Frequencies and diversity of katakana words and high-frequency ELWs

- Types of borrowing of high-frequency ELWs

- Semantic categories of high-frequency ELWs

\section{Research Question 2:}

Based on the results of the Language Attitude and Pervasion Survey (NINJAL, 2006), to what extent do people over 60 years old comprehend high-frequency ELWs, and how does their comprehension compare across registers? 


\section{Chapter 3}

\section{Methodology}

This chapter introduces the data and the analysis procedures for the study. The first section provides the background for the data source for this study, followed by the second section, which describes the data in detail. The third section outlines the analysis procedures that guided this study.

\section{Background: The BCCWJ and the Monitor Data}

The source of the data for this study, the Balanced Corpus of Contemporary Written Japanese Monitor Data 2009 (The Monitor Data), is a subset of a larger and more comprehensive corpus, the Balanced Corpus of Contemporary Written Japanese (The BCCWJ) (NINJAL 2011).

The BCCWJ was developed between 2006 and 2011 as part of a long-term Japanese language research project known as the Kotonoha Project conducted by the National Institute for Japanese Language and Linguistics (NINJAL, 2010; 2011). It contains over 100 million words and consists of three sub-corpora: 1) the Publication corpus, 2) the Library corpus, and 3) the Special-Purpose corpus (NINJAL, 2011). The Publication corpus consists of randomly selected samples of books, newspapers, and magazines published in Japan between 2001 and 2005, which represents the overall picture of the recent published written texts in the market. On the other hand, the Library corpus is a collection of randomly selected samples of books published between 1986 and 2005 that are included in the library catalogues in thirteen public libraries in the Tokyo Metropolitan Area. Therefore, samples in the Library corpus represent books that were not only published, but also have wide circulation among the public. Lastly, the Special- 
Purpose corpus contains various types of context-specific texts that may or may not have been published, such as governmental documents, best-selling books (the top 20 of the year), textbooks, laws, Yahoo! Blog, and Yahoo! Chiebukuro (知恵袋), which is the Japanese equivalent of Yahoo! Answer. For the governmental documents, there are several types of texts including white papers (authoritative reports issued by the government) and the Diet meeting minutes (official records of the proceedings of national government meetings). Some of the texts in the Special-Purpose corpus date back to 1976, while some are as recent as 2005. In summary, the BCCWJ includes various types of texts that range from government-issued documents, which are one of the most formal registers of writing, to internet texts, where authors are anonymous, carefree, and is likely informal.

In 2009, while the BCCWJ was still under compilation, the Balanced Corpus of Contemporary Written Japanese Monitor Data 2009 (The Monitor Data) was published as an interim resource for research purposes (Maruyama, 2009). The Monitor Data is a subset of the BCCWJ with the same basic structure, consisting of approximately 45 million words and the same three sub-corpora. The major difference between the complete BCCWJ and the Monitor Data is the extent of text coverage; while the Publication corpus in the BCCWJ includes magazines and newspapers, the Monitor Data only contains books. Also, although the Special-Purpose corpus in the BCCWJ Monitor Data contains nine types of texts, the Monitor Data includes four: best-selling books, white papers, Diet meeting minutes, and Yahoo! Chiebukuro. Despite the smaller range of text type, however, the Monitor Data contains many samples of governmental documents and internet texts, which represent the formal and informal registers of 
writing, and of books that represent registers of neutral formality. In fact, in order to reach a data size feasible for the analysis, I selected specific parts of the Monitor Data, as described in the following section.

\section{The Data}

For the purpose of the study, which was to investigate the characteristics of ELWs found in recently written Japanese texts in three registers, I made the following decisions in selecting the data. First, I limited my data to texts from 2001 to 2005 in all three corpora in order to align the period of time when the texts were produced, as well as to keep the size of the data feasible for my study. Second, I excluded the Library corpus and the Best-seller corpus from the data because the Publication corpus alone contained 4,459 samples, which provided large and comprehensive enough data for the book register. Furthermore, I decided to exclude Diet meeting minutes from the data because they were transcripts of the spoken dialogue during the meeting, which was inherently different from the written language. As a result, the following corpora constituted the data for the study: white papers, books, and Yahoo! Chiebukuro, representing the three registers, i) government-issued reports, ii) books, and iii) internet texts, respectively (Table 4). The word counts for each corpus in Table 4 were calculated in the initial stage of the analyses, which will be described in detail in the data analysis procedure section.

Table 4: The data of the study

\begin{tabular}{|l|r|r|r|r|}
\hline Register & $\begin{array}{c}\text { Government- } \\
\text { issued Reports }\end{array}$ & \multicolumn{1}{|c|}{ Books } & Internet texts & \multirow{2}{*}{ Overall } \\
\cline { 1 - 2 } $\begin{array}{l}\text { Corpus } \\
\text { (Source) }\end{array}$ & $\begin{array}{c}\text { White papers } \\
\text { (Special-Purpose) }\end{array}$ & $\begin{array}{c}\text { Books } \\
\text { (Publication) }\end{array}$ & $\begin{array}{c}\text { Yahoo! Chiebukuro } \\
\text { (Special-Purpose) }\end{array}$ & \\
\hline Year & $2001-2005$ & $2001-2005$ & $2001-2005$ & $2001-2005$ \\
\hline \# of Samples & 250 & 4,459 & 45,725 & 50,434 \\
\hline \# of words & 828,000 & $12,700,000$ & $5,239,000$ & $18,767,000$ \\
\hline
\end{tabular}


Each corpus includes various topic categories. Maruyama (2009) identified 11 major categories for the books, nine for the white papers, and 14 for the Yahoo texts (Table 5). While all three corpora included topics related to economy, science, and society in general, some categories were unique to the register. For instance, the white paper corpus included texts that are specific to national governmental functions, such as security and foreign diplomacy, while the Yahoo corpus included categories that are distinctly personal, such as entertainment and hobbies, occupation and career, and parenting and schools.

Table 5: Topic categories in white papers, books, and internet texts

\begin{tabular}{|c|c|c|}
\hline White papers & Books & Internet texts \\
\hline $\begin{array}{ll}\text { 1. } & \text { Security } \\
\text { 2. } & \text { Foreign diplomacy } \\
\text { 3. } & \text { Science and technology } \\
\text { 4. } & \text { Environment } \\
\text { 5. } & \text { Education } \\
\text { 6. } & \text { Economy } \\
\text { 7. } & \text { Welfare } \\
\text { 8. } & \text { Agriculture and fishery } \\
\text { 9. } & \text { Land, infrastructure and } \\
& \text { transport }\end{array}$ & $\begin{array}{ll}\text { 1. } & \text { General } \\
\text { 2. } & \text { Philosophy } \\
\text { 3. } & \text { History } \\
\text { 4. } & \text { Social science } \\
\text { 5. } & \text { Natural science } \\
\text { 6. } & \text { Technology and } \\
& \text { engineering } \\
\text { 7. } & \text { Industry and commerce } \\
\text { 8. } & \text { Arts } \\
\text { 9. } & \text { Language } \\
\text { 10. } & \text { Literature } \\
\text { 11. } & \text { No category }\end{array}$ & 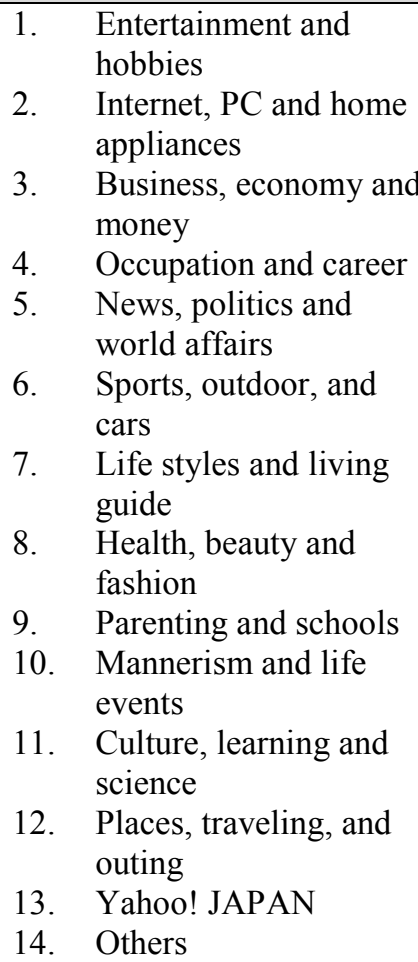 \\
\hline
\end{tabular}

In summary, the data used in this study were from three corpora that consist of three distinct registers: white papers, books, and internet texts. Each corpus includes a wide variety of topics, some of which are unique to one register while some are shared by 
all three. The sizes of the corpora vary, but they are large and principled enough for the scope of this study.

\section{Data Analysis Procedures}

The analysis procedures of this study are divided into five stages. For the first stage, I used UniDic (Den, et. al, 2007) to modify the data, which included both word and non-word units, and created a modified corpus that only consists of words for each register. The purposes of this step were to obtain the number of words in preparation for the subsequent frequency analysis, and to collect information that helped identify loan words. For the second stage, I created a list of katakana words (Western loan words) and analyzed their frequencies. Then, I extracted high-frequent katakana words of English origin, and created the high-frequency ELW list. For the third stage, I analyzed the semantic properties of high-frequency ELWs based on the semantic categories that emerged from the data. For the fourth stage, I analyzed the types of high-frequency ELWs based on the core/cultural distinction adapted from Myers-Scotton (2006). Finally, I compared the high-frequency ELWs with the loan words surveyed in Language Attitude and Pervasion Survey (NINJAL, 2006) and identified the extent to which people over 60 years old comprehended high-frequency ELWs. The following subsections provide the detailed descriptions of the five stages.

Stage 1: Using UniDic to modify the corpora. UniDic (Den, et. al, 2007) is a Japanese corpus analysis tool developed under the supervision of NINJAL. UniDic is commonly used for recent Japanese corpus research and was available for download online. The basic function of UniDic is to transform sentences into units of words and/or non-words, such as symbols, punctuations, and letters. Texts loaded in UniDic are 
returned as a list of units with their descriptions, including, but not limited to: 1) the lexeme (語彙素), 2) written form (書字形), 3) part of speech (品詞), and 4) the word type (語種) (Kokiso \& Nakamura, 2009). The lexeme information provides the dictionary form of the word in standard Japanese dictionaries, which may be different from its written form, as there are four types of scripts in Japanese: hiragana, katakana, kanji, and the Roman alphabet. For example, the loan word page may be written in four different scripts depending on the style or the intent of the author, as in ペーじ (hiragana), ページ(katakana), 頁 (kanji), and page (the Roman alphabet). Still, all of them point to the same lexeme, ページ, which is written in katakana because katakana is the standard script for Western loan words. The part of speech description provides the grammatical information for word units (e.g. verb, noun, modal verb), and the types of symbols for non-word units (e.g. bracket, punctuation, exclamation). The word type description provides information about the origin of the word, such as Japanese (和), Chinese (漢), or as indicated as gairaigo (外来語), which are other foreign languages.

In order to create corpora that only consisted of words, I used the part of speech descriptions provided by UniDic to separate word and non-word units. In UniDic, nonword units are classified as variations of symbols. For example, the unit " $<$ " is classified as “symbol-open bracket” (記号-括弧開), and “。” is classified as “auxiliary symbol” (補助記号). Also, I treated symbol-like numerals as non-word units, such as Roman numerals (e.g. I, II, III) and circled numbers (e.g. (1), (2), (3)). On the other hand, I treated words that are often written in symbols, such as percent $(\%)$, plus $(+)$, and minus (-) as word units because they are processed as words with essential meanings in the 
reader's mind. After all non-word units were removed, the remaining units constituted the modified corpora for the three registers. The corpora are stored as a table that could be organized by the descriptive fields provided by UniDic (Figure 3).

Figure 3: Example of modified corpus organized by the lexeme (White Paper)

\begin{tabular}{|c|c|c|c|c|c|c|c|c|c|}
\hline $\begin{array}{c}\text { 出典 } \\
\text { (Sample ID) }\end{array}$ & $\begin{array}{c}\text { 語莗素 } \\
\text { (Lexeme) }\end{array}$ & $\begin{array}{c}\text { 書字形 } \\
\text { (Written } \\
\text { form) }\end{array}$ & $\begin{array}{c}\text { 発音形 } \\
\text { (Pronunciation) }\end{array}$ & $\begin{array}{c}\text { 語彚素読み } \\
\text { (Lexeme } \\
\text { reading) }\end{array}$ & $\begin{array}{c}\text { 咕阔 } \\
\text { (Part of speech) }\end{array}$ & $\begin{array}{c}\text { 活用型 } \\
\text { (Inflection type) }\end{array}$ & $\begin{array}{c}\text { 活用形 } \\
\text { (Inflecton form) }\end{array}$ & $\begin{array}{c}\text { 語形 } \\
\text { (Word form) }\end{array}$ & $\begin{array}{c}\text { 語程 } \\
\text { (Word type) }\end{array}$ \\
\hline OW6X_00028.txt & 啓発 & 啓発 & ケーハツ & ケイハツ & 名詞-普通名袷-サ变可能 & & & ケイハツ & 漢 \\
\hline OW6X_00028.txt & 敬発 & 啓発 & ケーハツ & ケイハツ & 名湖-普通名滴-サ变可能 & & & ケイハツ & 漢 \\
\hline OW6X_00028.txt & 型 & 型 & ガ夕 & ガ夕 & 接尾辞-名嚁的-一般 & & & ガ夕 & 和 \\
\hline OW6X_00028.txt & 型 & 型 & 加夕 & ガ夕 & 接尾辞-名洞的-一般 & & & 加夕 & 和 \\
\hline OW6X_00028.txt & 契約 & 契約 & ケーヤク & ケイヤク & 名詞-普通名眮-サ变可能 & & & ケイヤク & 漢 \\
\hline OW6X_00028.txt & 契约 & 契约 & ケーヤク & ケイヤク & 名洞-普通名調-サ变可能 & & & ケイヤク & 漢 \\
\hline OW6X_00028.txt & 形成 & 形成 & ケーセー & ケイセイ & 名詞-普通名調-サ变可能 & & & ケイセイ & 漢 \\
\hline OW6X_00028.txt & 形態 & 形㲟 & ケータイ & ケイタイ & 名洞-普通名裙-一般 & & & ケイタイ & 漢 \\
\hline OW6X_00028.txt & 掘げる & 掘任 & 肪ゲ & カカゲル & 動詞-一般 & 下一段-カ行 & 連用形-一般 & カカゲル & 和 \\
\hline OW6X_00028.txt & 梮げる & 据 & カカゲ & カカゲル & 動辟-一般 & 下一段-カ行 & 連用形-一般 & カカゲル & 和 \\
\hline OW6X_00116.txt & ペーシ் & 頁 & ペーシ் & ページ & 名洞-普通名铜-一般 & & & ページ & 外 \\
\hline OW6X_00116.txt & ペl & べき & ベキ & ベシ & 助動调 & 文語助偊碋-ベシ & 連体形-一般 & ベシ & 和 \\
\hline OW6X_00116.txt & ヘ́l & べき & ベキ & $ヘ ゚$ & 助動阔 & 文語助動喏-ベシ & 連体形-一般 & ベシ & 和 \\
\hline OW6 X_00116.txt & ベし & べき & ベキ & ベシ & 助動詞 & 文語助動司-ペシ & 连体形-一般 & ベシ & 和 \\
\hline OW6X_00116.txt & ベット゚ & ベッド & ベッド & ベッド & 名閁-普通名詷-一般 & & & ベッド & 外 \\
\hline OW6X_00116.txt & ベット゚ & ベッド & ベット゚ & ベッド & 名洞-普通名淯-一般 & & & ベッド & 外 \\
\hline
\end{tabular}

One unique feature of Yahoo! Chiebukuro samples was that each sample included a topic title under which Q \& A was posted. For example, the following text is a sample from the topic "Yahoo! Auction," in which the word auction appeared twice: once as a topic title (underlined) and once as a part of the sentence in the question (bolded).

Yahoo! オークション

オークションの出品物にアクセスした人が誰か（I D ）判るのですか? 入札した人か質問した人しか分かりませんよ。第三者に分かるのは入札と、 回答を 貪った質問者だけ。アクセスとウォッチリストは件数のみ。

Yahoo! Auction

Can people see who (ID) accessed [viewed] the items in the auction?

You can only see people who bid on the item and asked questions. A third party can only see the bidders and the people who received answers to their questions. As for accessing [viewing] and watch-list, you can only see the numbers [of people]. 
Since the topic titles are automatically included in the text, not produced by the author, their occurrences should not be counted. Thus, in order to only count the occurrences of words that authors intentionally used, I excluded the occurrences of words that appeared as topic titles in Yahoo! Chiebukuro.

Stage 2: Extracting katakana words and high-frequency ELWs. The next step was to investigate the overall size of katakana words by extracting the katakana words and identifying their frequencies in each modified corpus. In order to identify katakana words, I first sorted the words by the word type (語種) and identified gairaigo (foreign words), which included both katakana and non-katakana loan words. For example, words that originate from Sanskrit and Ainu (the language used by the native Ainu people in Japan) are considered gairaigo. These gairaigo, however, are not written in katakana, but typically in kanji instead, as in 奈落 (naraku) from the Sanskrit word naraka. In order to separate katakana and non-katakana words, I sorted the gairaigo by the lexeme (語彙素) and removed all non-katakana words based on the script type in the lexeme column. The remaining gairaigo constituted the katakana list, which contained all the occurrences of katakana words.

After katakana words were extracted, I identified the raw counts of katakana words in each register and identified the normed frequency per one million words. Next, I counted the number of distinct katakana words and their frequencies. After obtaining the frequencies for each distinct katakana words, I compared the three registers and determined the frequency level that would constitute the high-frequency word group based on the following two factors: 1) there should be substantial number of words from 
each corpus for register comparison, and 2) the number of words feasible for further analyses. As a result, I determined the high-frequency level to be a normed frequency of 30 times or more per million words.

Subsequently, I evaluated the high-frequency katakana words for their language origin in order to eliminate non-English loan words. To do this, I removed ones that are not included in contemporary English vocabulary, such as arbeit (German) and konbinat (Russian). Words that originate from non-English language, but are considered a typical vocabulary item in English, remained in the list (e.g. tobacco, beer). The remaining katakana words constituted the high-frequency ELWs, which would be further analyzed in the next stages.

Additionally, in order to identify the diversity of katakana words and highfrequency ELWs, I calculated their type-token-ratio (TTR) by dividing the number of distinct vocabulary items by the raw counts of katakana and high-frequency ELWs.

Stage 3: Analyzing types of borrowing. In order to characterize the types of borrowing for the high-frequency ELWs, I adapted the core/cultural distinction described by Myers-Scotton (2006) and used the following definitions: 1) Core borrowing: Loan words that duplicate elements of Japanese words already in existence and 2) Cultural: Words that fill gaps in Japanese vocabulary because they stand for objects or concepts new to Japanese culture. For instance, the ELW drink (noun) refers to beverages in general, for which Japanese already had its own word, nomimono. Therefore, I categorized drink as a core borrowing. In contrast, the ELW beer refers to a specific kind of drink that was new to Japanese culture. Therefore, I categorized beer as a cultural borrowing. 
However, the distinction between core and cultural borrowing was not always clear-cut; ELWs that stand for objects or concepts that are roughly equivalent of what already exist in Japanese, but only refer to the "Western-style" versions of them, have characteristics of both core and cultural borrowing. For example, the ELW hotel is a core borrowing in the sense that the concept of lodging and words that stand for it already existed in Japanese culture. However, the specific type of lodging that hotel refers to was new to Japan; hotel is only used to refer to a western-style lodging with western-furniture and utilities, such as a bed and an individual shower room, whereas the Japanese word ryokan generally refers to a traditional Japanese-style lodging with futon mattress on the floor and a public bath. In this sense, the elements of hotel do not duplicate those of the Japanese-style lodging, ryokan, hence the ELW hotel is a cultural borrowing. In order to account for ELWs that have the characteristics of both core and cultural borrowing, I created the third type of borrowing: 3) Core-Western: Words that duplicate the general elements that already exist in Japanese, but only refer to the western-versions of them.

For words that convey multiple meanings that include both existing and new objects or concepts, I created a fourth category: 4) Core/Cultural: Words that refer to multiple objects or concepts, some of which are core borrowings and some are cultural borrowings. For example, the ELW address is a Core/Cultural borrowing because it can refer to a physical location and/or a virtual destination, such as IP address and email address. It is a core borrowing in a sense that the concept of physical location is a duplicate of the Japanese word jusho. However, it is a cultural borrowing when it is referring to IP address or email address because there is no Japanese word to replace it. 
Summing up, the following four definitions guided my analysis of the type of borrowing:

1) Core borrowing: Words that duplicate elements of Japanese words already in existence

2) Cultural borrowing: Words that fill gaps in Japanese vocabulary because they stand for objects or concepts new to Japanese culture

3) Core-Western borrowing: Words that duplicate general elements of Japanese words already in existence, but only refer to the western-versions of them

4) Core/Cultural borrowing: Words that refer to multiple objects or concepts, some of which are core borrowings and some of which are cultural borrowings

Stage 4: Analyzing semantic categories of high-frequency ELWs. In this stage, in order to describe the semantic characteristics of the high-frequency ELWs, I created the semantic categories through an inductive process, and then compared their proportions.

To create the semantic categories, I first surveyed the high-frequency ELWs list and identified their basic semantic properties, such as people, food, concept, and place, based on my cultural knowledge of the words' common meanings in the Japanese context. Additionally, I also consulted with the Sanseido Japanese Dictionary, which is considered one of the standard Japanese dictionaries, in order to get a sense of how these ELWs are commonly used. Then, based on these meanings, I identified the themes and contexts with which the word is most likely to be associated, and created the theme-based categories. For instance, food-related words, such as restaurant, wine, and cheese, are 
most likely to be used in association with dining experiences; therefore, I created the category Dining and Food.

While many of the high-frequency ELWs had identifiable themes and contexts, some of them were ambiguous in two ways. The first was when the ELW's meaning was so general that there was no single theme-based category to assign them. For example, the ELW advice is not attached to any theme or context; whatever the situation is, advice maintains one general meaning. Therefore, I created a non-theme-based category, General Meaning. Also, function words, such as pronouns, prepositions, and conjunctions are used regardless of contexts, and their basic meanings and functions remain the same, so I categorized these ELWs in the General Meaning category.

The second type of semantic ambiguity was due to the polysemous nature of certain words. In this case, the ELWs had multiple meanings that were distantly related, but conveyed different meanings depending on the context. For example, the ELW window could possibly refer to two items: a panel with a sheet of glass or the popular operating system, Microsoft Windows. For such ELWs, I created another non-themebased category, Multiple Meanings.

In order to determine the semantic categories for the ELWs in a principled manner, I applied two tests:

Test 1: Does the ELW have more than one meaning?

Test 2: Does the ELW belong to more than one theme-based category? Figure 4 illustrates how the results of these tests determined the semantic categories of the high-frequency ELWs. 
Figure 4: Semantic category assignment tests

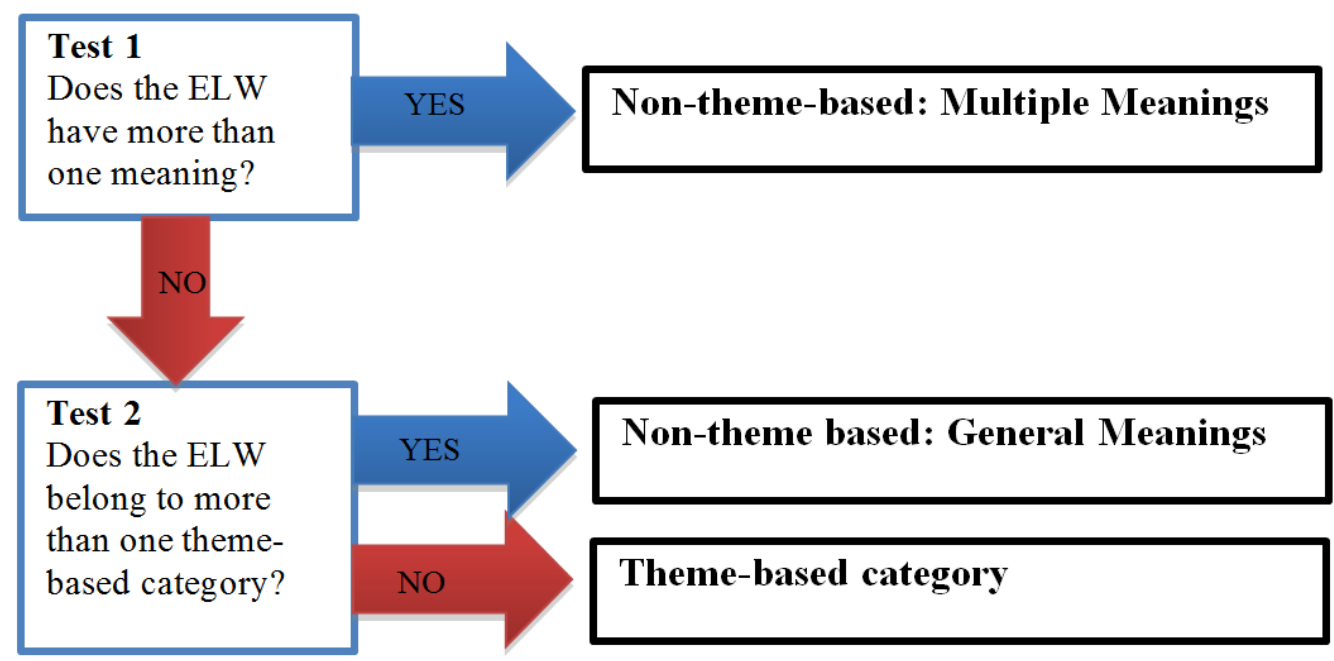

Stage 5: Identifying comprehension rates of high-frequency ELWs. The final stage of this study was to investigate the extent to which Japanese people over 60 years old are likely to comprehend the high-frequency ELWs. To do this, I used the existing study results from Gairaigo teichakudo chousa (NINJAL, 2006), which, as discussed in the literature review, identified people's comprehension rates for approximately 400 loan words. In order to identify the comprehension rates for the high-frequency ELWs, I compared the two lists of ELWs: the high-frequency ELW list in the present study and the NINJAL survey list, and identified the ELWs found in both lists. Then, I analyzed these ELWs with respect to the rates of comprehension, their types of borrowing, and semantic categories.

\section{Chapter Summary}

This chapter has presented the data and the analysis procedures for the study. All stages described here were sequential, each preparing itself for the next stages of analysis. The first stage, in which I used UniDic to transform texts into units and organize them, prepared the data for all the subsequent stages. The second stage, in which I 
analyzed the frequencies of katakana words and the high-frequency ELWs, identified ELWs commonly used in each register and how they compared across three registers. The third and fourth stages, in which I analyzed the types of borrowing and semantic categories of the high-frequency ELWs, provided information that characterized commonly used ELWs in each register. In the fifth stage, I analyzed the high-frequency ELWs with respect to the comprehension rates and investigated how they compare among the registers. The results of the analyses are presented in the next chapter. 


\section{Chapter 4}

\section{Results and Discussion}

This chapter presents the results of the study. As outlined in the previous chapter, the analyses were focused on the following:

1) Frequencies and diversity of katakana words and high-frequency ELWs

2) Types of borrowing of high-frequency ELWs

3) Semantic categories of high-frequency ELWs

4) Comprehension rates of high-frequency ELWs

\section{Katakana Words and High-frequency ELWs}

Frequency: Katakana words. The frequencies of katakana words as a whole were extremely high for all three registers: 21,500 times per one million words $(21,500 / \mathrm{M})$ for white papers, $20,400 / \mathrm{M}$ for books, and 36,000/M for internet texts (Table 6). In comparison to some of the very common words in English, words that occur at the frequency of around 20,000/M include $a$, of, and in (Davis, 2012). Such high frequencies of katakana words, most of which are ELWs, supported both the common perception and the previous reports about the prevalence of ELWs.

Frequency: High-frequency ELWs. As discussed in the previous chapter, a high-frequency word in this study means any word that recurs 30 or more times per one million words ( $>30 / \mathrm{M})$. I found 128 high-frequency ELWs in white papers, 106 in books, and 254 in internet texts, and 338 overall. The frequency of the high-frequency ELWs per register was highest in internet texts $(18,047 / M)$, followed by white papers $(14,293 / M)$, and books (6,072/M) (Table 6). 
Table 6: Diversity and frequency of katakana words and high-frequency ELWs

\begin{tabular}{|l|r|r|r|r|}
\hline & White Papers & \multicolumn{1}{|c|}{ Books } & Internet Texts & \multicolumn{1}{c|}{ Overall } \\
\hline Katakana word frequency & $21.500 / \mathrm{M}$ & $20,400 / \mathrm{M}$ & $36,000 / \mathrm{M}$ & $24,800 / \mathrm{M}$ \\
\hline Distinct katakana words & 1,553 & 9,494 & 6,551 & 10,854 \\
\hline High-freq. ELW frequency & $14,293 / \mathrm{M}$ & $6,072 / \mathrm{M}$ & $18,047 / \mathrm{M}$ & $9,778 / \mathrm{M}$ \\
\hline Distinct high-freq. ELWs & 128 & 106 & 254 & 338 \\
\hline
\end{tabular}

Figure 5 illustrates the frequencies of katakana words and high-frequency ELWs. As shown, the orders of the frequencies were the same for katakana words and highfrequency ELWs; however, the differences among the registers were much greater for high-frequency ELWs than those of katakana words.

Figure 5: Frequencies of katakana words and high-frequency ELWs

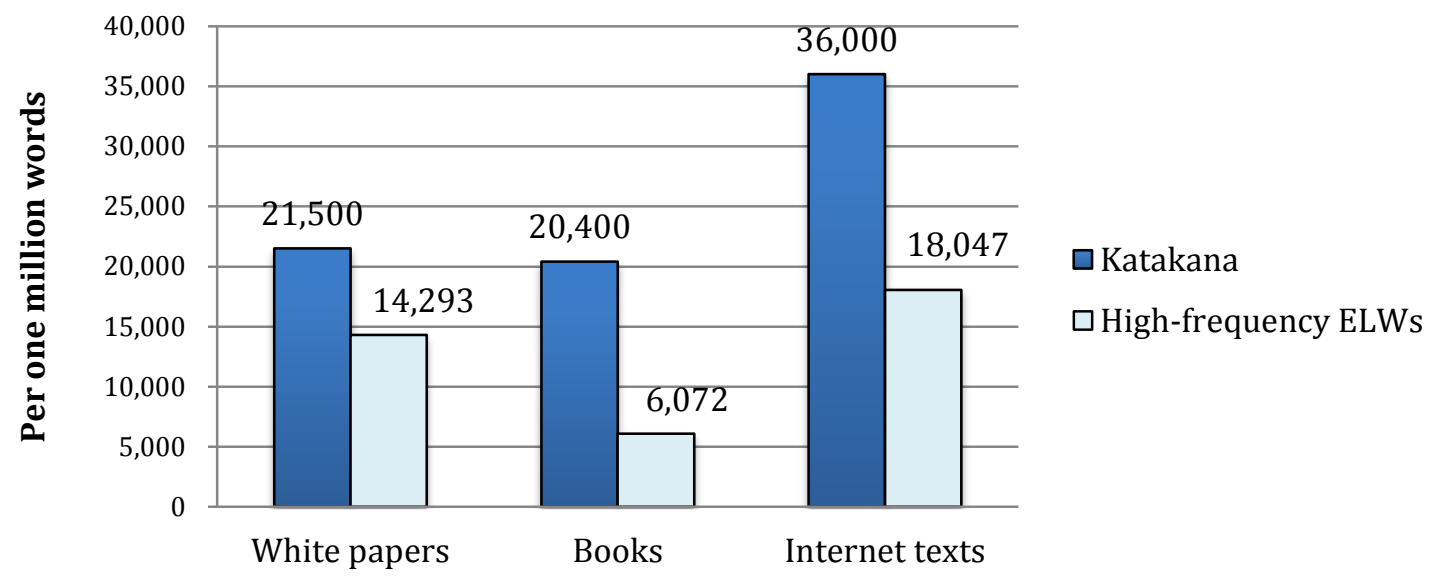

For white papers, approximately $66 \%$ of the katakana word occurrences were also high-frequency ELWs, while only $30 \%$ in books and $50 \%$ in internet texts were. In other words, the majority of katakana word occurrences in books were instances of nonfrequent ELWs, which readers are less likely to encounter repeatedly. On the other hand, the majority of katakana word occurrences in white papers were instances of highfrequency ELWs, which readers are likely to encounter again and again. For internet texts, only half of the katakana words were high-frequency ELWs, although given their overall frequencies, readers are still likely to encounter these ELWs at a very high rate. 
Lexical diversity. I also found that there were noticeable differences in the lexical diversity among the registers, which provided additional information helpful for characterizing ELWs in each register. Figure 6 shows the Type-Token-Ratio (TTR) of katakana words and high-frequency ELWs. As shown, the TTR for katakana words was the highest in white papers $(0.087)$, followed by books $(0.037)$ and internet texts $(0.035)$, which meant that katakana words in white papers were much more diverse than ones in other registers. The same was true for high-frequency ELWs; the TTR was the highest in white papers $(0.0108)$, followed by internet texts $(0.0027)$ and books $(0.0014)$. Thus, white papers, though their overall frequency is not as high as internet texts, had a much more diverse group of ELWs than internet texts. Internet texts, on the other hand, had the highest overall frequency but their lexical diversity was not as great as white papers. ELWs in books were neither frequent nor diverse.

Figure 6: TTR comparison of katakana words found in three registers

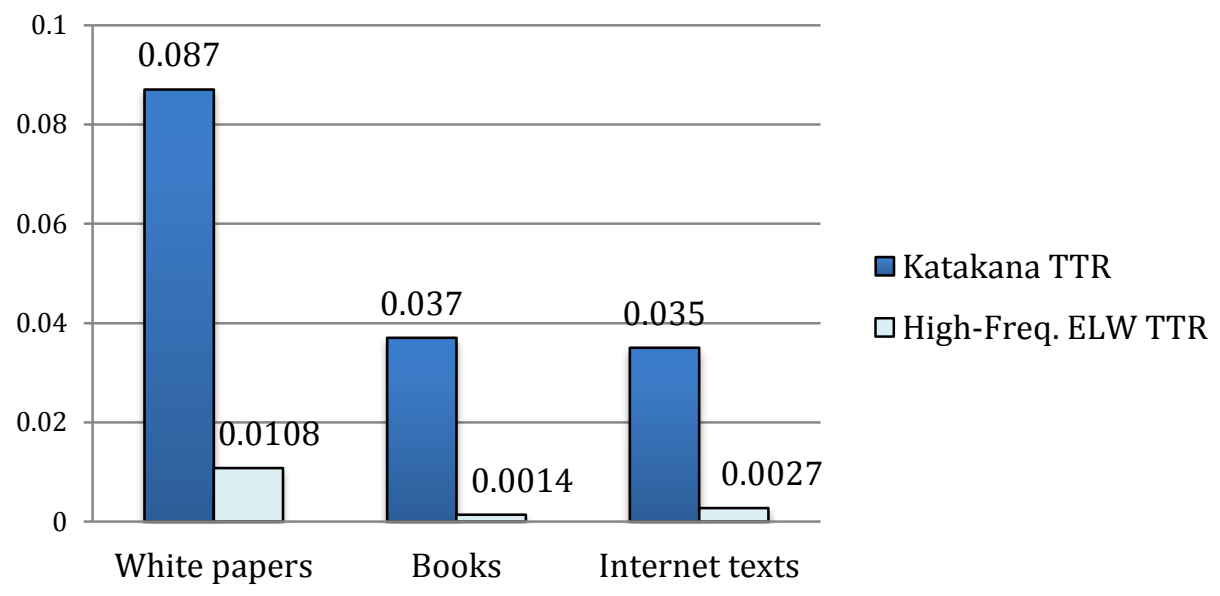

Register-specific ELWs. Some high-frequency ELWs were found in multiple registers, while some were exclusively found in one register. Table 7 presents the distribution of individual high-frequency ELW occurrences in the three registers. As shown, only $10 \%$ of the high-frequency ELWs appeared exclusively in books, which 
means that the vast majority of the ELWs in books were commonly used in other registers as well. In contrast, for internet texts, the majority (62\%) of the high-frequency ELWs were exclusive to internet texts. This means that the internet texts tend to contain ELWs that are not used in any other registers. For white papers, the distribution was relatively moderate, as about a half (46\%) of the high-frequency ELWs appeared only in white papers, while the rest were commonly used in other registers as well. In sum, the distributions of the individual high-frequency ELWs across registers suggests that some ELWs are register-free, while some are likely to be used only in a specific register. Most ELWs in books were found to be register-free, while ELWs in internet texts had a tendency to generally be register-specific. ELWs in white papers almost equally distributed between register-specific and register-free.

Table 7: Distribution of high-frequency ELWs

\begin{tabular}{|l|r|r|r|r|r|r|}
\hline \multirow{2}{*}{} & \multicolumn{2}{|c|}{ White papers } & \multicolumn{2}{c|}{ Books } & \multicolumn{2}{c|}{ Internet texts } \\
\cline { 2 - 7 } & $\begin{array}{c}\text { \# of } \\
\text { ELWs }\end{array}$ & \multicolumn{1}{c|}{$\begin{array}{c}\text { \# of } \\
\text { ELWs }\end{array}$} & \multicolumn{1}{c|}{$\begin{array}{c}\text { \# of } \\
\text { ELWs }\end{array}$} & \multicolumn{1}{c|}{$\%$} \\
\hline Exclusive to this sub-corpus & 59 & $(46 \%)$ & 11 & $(10 \%)$ & 157 & $(62 \%)$ \\
\hline In WP \& BK & 14 & $(11 \%)$ & 14 & $(13 \%)$ & ---- & ---- \\
\hline In WP \& IT & 17 & $(13 \%)$ & --- & --- & 16 & $(6 \%)$ \\
\hline In BK \& IT & ---- & --- & 42 & $(40 \%)$ & 42 & $(17 \%)$ \\
\hline In all three sub-corpora & 38 & $(30 \%)$ & 38 & $(37 \%)$ & 38 & $(15 \%)$ \\
\hline Total & 128 & $(100 \%)$ & 106 & $(100 \%)$ & 254 & $(100 \%)$ \\
\hline
\end{tabular}

Summary: Katakana words and high-frequency ELWs. As discussed so far, both katakana words and high-frequency ELWs were found most frequently in internet texts, followed by white papers, and finally books. In addition, ELWs in each register exhibited unique characteristics with regard to their lexical diversity and specificity. White papers, though their ELW frequency was not the highest, had the most diverse collection of ELWs, half of which were unique to white papers while the other half appeared in other registers as well. In other words, high-frequency ELWs in white papers 
were moderately frequent, diverse, and a mixture of register-specific and non-registerspecific. On the other hand, high-frequency ELWs in internet texts were highly frequent, though their lexical diversity was not as great as white papers, and the majority of their ELWs were found only in internet texts. Thus, high-frequency ELWs in internet texts can be characterized as a group of words that are not very diverse or common in other registers but their frequency as a whole is extremely high. Lastly, high-frequency ELWs in books were the least frequent and diverse, but were the most commonly used across registers.

\section{Types of Borrowing}

As discussed in the previous chapter, types of borrowing indicate the loan word's function and its relationship with its Japanese equivalent, if there is any. The sorting of the types were based on the following classifications:

1) Core borrowing: Words that duplicate elements of Japanese words already in existence

2) Cultural borrowing: Words that fill gaps in Japanese vocabulary because they stand for objects or concepts new to Japanese culture

3) Core-Western borrowing: Words that duplicate general elements of Japanese words already in existence, but only refer to the western-versions of them

4) Core/Cultural borrowing: Words that refer to multiple objects or concepts, some of which are core borrowings and some of which are cultural borrowings

Distribution of the types of borrowing. Overall, the most common type of borrowing was core borrowing (196 ELWs, 5,079/M), followed by cultural (91 ELWs, 2,928/M), core/cultural (35 ELWs, 1,370/M), and core-western (16 ELWs; 401/M). Figure 7 illustrates the proportions of the types of borrowing based on the frequency. 
Figure 7: Proportions of the types of borrowing by register

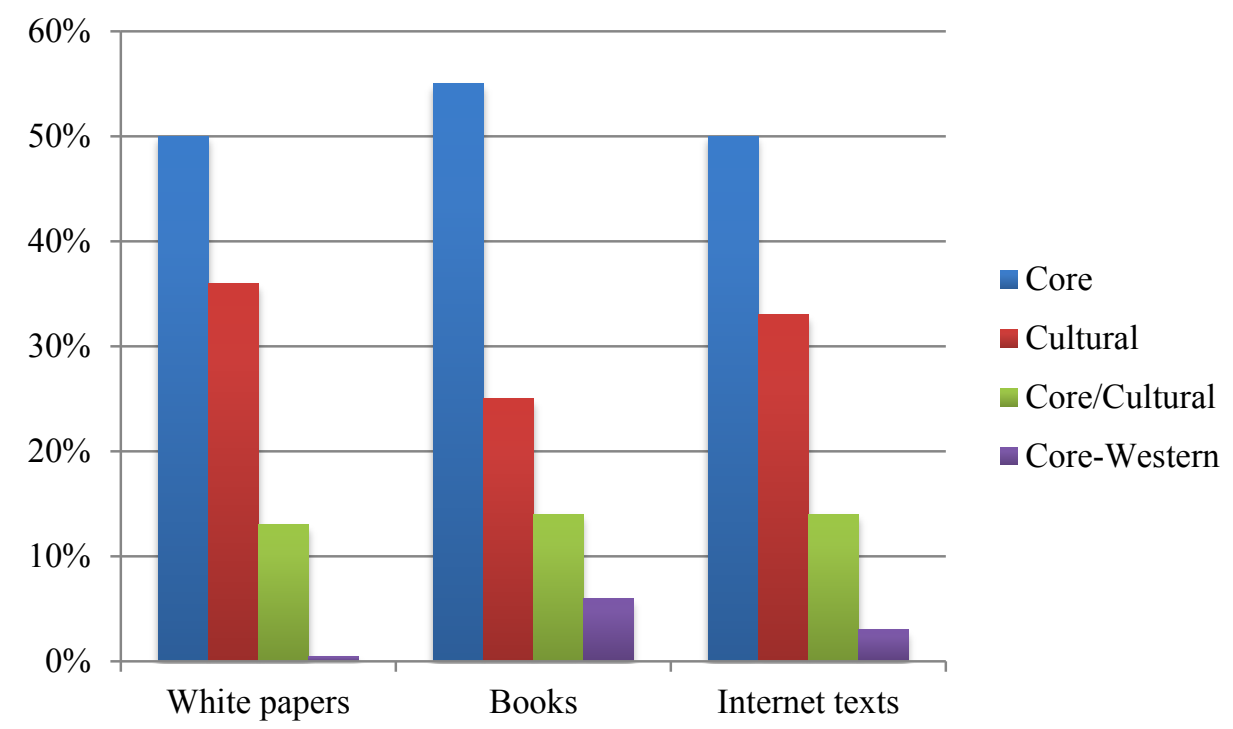

As illustrated in Figure 7, the order of frequencies was the same for all registers, with core borrowings being the most frequent, followed by cultural, core/cultural, and core-western. The proportions of the types were also similar across registers, except for books, in which cultural borrowings were approximately $10 \%$ less common than books and internet texts. For all other types, the differences were within 5\%.

Although core borrowing as a whole was the most common type of borrowing, I found that some cultural and core/cultural borrowing ELWs occurred much more frequently than core borrowing ELWs (Table 8). For example, the cultural ELW percent in white papers had the highest frequency $(2,841 / \mathrm{M})$ in any type of borrowing or register, and was considerably higher than the most frequent core borrowing ELW, system (782/M). Similarly, in the books and internet texts, the most frequent cultural borrowing ELWs had a higher frequency than the most frequent core borrowing ELWs. These ELWs are bolded in Table 8. To sum, there were small groups of cultural and 
core/cultural ELWs that occurred exceptionally frequently, especially in internet texts, while the overall frequency was the highest for core borrowing ELWs.

Table 8: Three most frequent ELWs

\begin{tabular}{|l|r|r|r|}
\hline & White papers & Books & \multicolumn{1}{|c|}{ Internet texts } \\
\hline \multirow{3}{*}{ Core } & system $(782 / \mathrm{M})$ & system $(181 / \mathrm{M})$ & auction $(294 / \mathrm{M})$ \\
& service $(596 / \mathrm{M})$ & service $(164 / \mathrm{M})$ & maker $(193 / \mathrm{M})$ \\
& center $(410 / \mathrm{M})$ & model $(120 / \mathrm{M})$ & talent $(179 / \mathrm{M})$ \\
\hline \multirow{3}{*}{ Cultural } & percent $(2841 / \mathrm{M})$ & percent $(341 / \mathrm{M})$ & mail $(\mathbf{8 0 4} / \mathrm{M})$ \\
& Internet $(346 / \mathrm{M})$ & meter $(114 / \mathrm{M})$ & site $(392 / \mathrm{M})$ \\
& digital $(194 / \mathrm{M})$ & television $(101 / \mathrm{M})$ & percent $(337 / \mathrm{M})$ \\
\hline \multirow{2}{*}{ Core/Cultural } & network $(363 / \mathrm{M})$ & page $(270 / \mathrm{M})$ & soft $(299 / \mathrm{M})$ \\
& data $(251 / \mathrm{M})$ & data $(129 / \mathrm{M})$ & page $(256 / \mathrm{M})$ \\
& home $(176 / \mathrm{M})$ & image $(86 / \mathrm{M})$ & card $(203 / \mathrm{M})$ \\
\hline \multirow{2}{*}{ Core- } & building $(53 / \mathrm{M})$ & hotel $(85 / \mathrm{M})$ & hotel $(111 / \mathrm{M})$ \\
Western & (none other) & door $(68 / \mathrm{M})$ & bar $(74 / \mathrm{M})$ \\
& & bed $(60 / \mathrm{M})$ & door $(62 / \mathrm{M})$ \\
\hline
\end{tabular}

Core borrowing ELWs and their Japanese equivalents. As defined above, core borrowing ELWs duplicate elements of Japanese words that already existed before the importation, which suggests either that they are used interchangeably or in distinct manners. It was beyond the scope of this study to differentiate the use of all core borrowings ELWs I found, but in my preliminary observation, I found both cases. An example of core borrowing ELW being used interchangeably with its Japanese equivalent is the ELW アドバイス,advice’ (adobaisu), whose Japanese equivalent is 助言 (jogen):

...専門家のアドバイスを受けながら ...プログラムづくりを進めていきまし た

(... senmonka no adobaisu o ukenagara...puroguramu zukuri o susumeteikimashia)

„... receiving advice from experts...(we) created the program'

...筆者の助言を受けながら ...研究と実践を行った

(...hissha no jogen o ukenagara...kenkyuu to jissen o okonatta)

„... receiving jogen from the author...(they) conducted research and implemented (it)' 
In the above sentences, the ELW advice and the Japanese word jogen occurr in a very similar manner, both semantically and structurally. In both sentences, someone received advice or jogen from an authority (the expert/author) as he or she worked on a task (creating the program/conducting research), and what they received, whether a piece of advice or jogen, mean the same thing. Other evidence for advice and jogen sharing a similar property as a word is that they can form a verb (to advise) with the addition of る (suru, ,to do') in the exact same manner, as in アドバイスする (adobaisu suru, ,to advise') and 助言する (jogen suru, ,fo advise'). Thus, core borrowing ELWs can indeed coexist alongside their Japanese equivalents and be used interchangeably.

However, some core borrowing ELWs and their Japanese equivalents were not always used in the same manner. For instance, the ELW ベスト (besuto), best' as an adjective is 最良の (sairyou-no). While I found many instances of the ELW best modifying both ELWs (e.g. ベストテン, besuto ten, ,best ten, '; ベストプラクティス, besuto purakuteisu, 'best practice') and Japanese words (e.g. ベストの状態, besuto no joutai, ,the best condition'; ベストな車, besuto na kuruna, ,the best car'), it was used overwhelmingly more with Japanese words, as in 最良の方法 (sairyou-no houhou) 'the best method' and 最良の治療 (sairyou-no chiryou), the best treatment.' Thus, although the core borrowing ELWs and their Japanese equivalents were synonymous, the ELWs were more flexible with what they could co-occur with than their Japanese equivalents, which preferred co-occurring with other Japanese words. 


\section{Semantic Categories of the High-Frequency ELWs}

The semantic categories of the high-frequency ELWs provided additional

characteristics for the three registers. As mentioned in Chapter 3, I identified the semantic categories based on the theme and context with which the ELW is most likely associated.

Theme-based semantic categories. I found thirteen theme-based semantic categories that include the following: Building \& Furniture; Dining \& Food; Economy \& Business; Material \& Substance; Measurements \& Units; Media \& Entertainment; Medical, Health, \& Beauty; Numeral \& Math; Personal \& Family Life; Science \& Technology; Social \& Public Life; Sports; and Vehicles. Table 9 presents the operational definitions and examples of ELWs in each theme-based category. As the names suggest, theme-based categories cover a very wide variety of themes, most of which are applicable to one's day-to-day life, ranging from family to society, economy, health, sports, numbers, and science and technology.

Non-theme-based semantic categories. As discussed in Chapter 3, ELWs with no identifiable theme or context with which they are likely to be associated with were categorized into one of the two non-theme-based categories, General Meaning and Multiple Meanings. Table 10 presents the operational definitions and example ELWs in the two non-theme-based categories, General Meaning and Multiple Meanings. 
Table 9: Thirteen theme-based semantic categories, their operational definitions, and example ELWs

\begin{tabular}{|c|c|c|c|}
\hline Category & Operational definitions & Example ELWs & Katakana form \\
\hline $\begin{array}{l}\text { Building \& } \\
\text { Furniture }\end{array}$ & $\begin{array}{l}\text { Building } \\
\text { Furniture }\end{array}$ & $\begin{array}{l}\text { building } \\
\text { door }\end{array}$ & ビルディング、ドア \\
\hline $\begin{array}{l}\text { Dining \& } \\
\text { Food }\end{array}$ & $\begin{array}{l}\text { Food/drinks } \\
\text { Places, items, or concepts } \\
\text { related to dining }\end{array}$ & curry, coffee, salad & $\begin{array}{l}\text { カレー、コーヒー、 } \\
\text { サラダ }\end{array}$ \\
\hline \multirow[t]{3}{*}{$\begin{array}{l}\text { Economy \& } \\
\text { Business }\end{array}$} & $\begin{array}{l}\text { Business concepts, activities, } \\
\text { or practice }\end{array}$ & auction, claim, cost & $\begin{array}{l}\text { オークション、 } \\
\text { クレーム、コスト }\end{array}$ \\
\hline & $\begin{array}{l}\text { Individuals, companies, or } \\
\text { organizations that conduct } \\
\text { business }\end{array}$ & $\begin{array}{l}\text { convenience store, } \\
\text { shop }\end{array}$ & $\begin{array}{l}\text { コンビニ(エンスストア }) \text {, } \\
\text { ショップ }\end{array}$ \\
\hline & $\begin{array}{l}\text { Currency or any form of } \\
\text { monetary fund }\end{array}$ & dollar, bonus & ドル、ボーナス \\
\hline $\begin{array}{l}\text { Material \& } \\
\text { Substance }\end{array}$ & Physical matter, material & $\begin{array}{l}\text { ion, uranium, gas, } \\
\text { gasoline }\end{array}$ & $\begin{array}{l}\text { イオン、ウラン、ガス、 } \\
\text { ガソリン }\end{array}$ \\
\hline \multirow{2}{*}{$\begin{array}{l}\text { Measuremen } \\
\text { ts \& Units }\end{array}$} & Extent, size, volume & calorie, gram & カロリー、グラム \\
\hline & Counting unit & percent & パーセント \\
\hline \multirow{3}{*}{$\begin{array}{l}\text { Media \& } \\
\text { Entertainme } \\
\text { nt }\end{array}$} & $\begin{array}{l}\text { Forms and/or types of } \\
\text { entertainment/media }\end{array}$ & anime, gamble, rock & $\begin{array}{l}\text { アニメ、ギャンブル、 } \\
\text { ロック }\end{array}$ \\
\hline & $\begin{array}{l}\text { Participants of } \\
\text { entertainment } / \text { media }\end{array}$ & talent, band & タレント、バンド \\
\hline & $\begin{array}{l}\text { Places, occasions, or mediums } \\
\text { for entertainment/media }\end{array}$ & show, tour, channel & $\begin{array}{l}\text { ショー、ツアー、 } \\
\text { チャンネル }\end{array}$ \\
\hline \multirow{2}{*}{$\begin{array}{l}\text { Medical, } \\
\text { Health \& } \\
\text { Beauty }\end{array}$} & $\begin{array}{l}\text { Medical terminologies and } \\
\text { healthcare related words }\end{array}$ & allergy, virus, stress & $\begin{array}{l}\text { アレルギー、ウイルス、 } \\
\text { ストレス }\end{array}$ \\
\hline & $\begin{array}{l}\text { Skincare, cosmetic, and hair } \\
\text { treatment }\end{array}$ & $\begin{array}{l}\text { care, cosmetic, } \\
\text { shampoo }\end{array}$ & $\begin{array}{l}\text { ケア、コスメティック、 } \\
\text { シャンプー }\end{array}$ \\
\hline $\begin{array}{l}\text { Numeral \& } \\
\text { Math }\end{array}$ & $\begin{array}{l}\text { Numbers } \\
\text { Concepts of mathematics }\end{array}$ & $\begin{array}{l}\text { eight, zero, plus, } \\
\text { minus }\end{array}$ & $\begin{array}{l}\text { エイト、ゼロ、プラス、 } \\
\text { マイナス }\end{array}$ \\
\hline \multirow[t]{3}{*}{$\begin{array}{l}\text { Personal \& } \\
\text { Family Life }\end{array}$} & $\begin{array}{l}\text { Family relationships, concepts, } \\
\text { and household items }\end{array}$ & pet, baby, mama & ペット、ベビー、ママ \\
\hline & $\begin{array}{l}\text { Relational concepts, activities, } \\
\text { events, and items }\end{array}$ & kiss, date, love, & キス、デート、ラブ \\
\hline & Clothing and fashion & Shirt, suit & シャツ、スーツ \\
\hline \multirow{2}{*}{$\begin{array}{l}\text { Science \& } \\
\text { Technology }\end{array}$} & Physical devices/inventions & camera, cable & カメラ、ケーブル \\
\hline & $\begin{array}{l}\text { Tools, products, concepts, and } \\
\text { participants of technology }\end{array}$ & analog, install, web & $\begin{array}{l}\text { アナログ、 } \\
\text { インストール、ウェブ }\end{array}$ \\
\hline \multirow[t]{2}{*}{$\begin{array}{l}\text { Social \& } \\
\text { Public Life }\end{array}$} & $\begin{array}{l}\text { Communal/social concepts, } \\
\text { activities, events, and items }\end{array}$ & event, manner & イベント、マナー \\
\hline & $\begin{array}{l}\text { Public/political concepts, } \\
\text { activities, events, and items }\end{array}$ & $\begin{array}{l}\text { initiative, guide, } \\
\text { guideline }\end{array}$ & $\begin{array}{l}\text { イニシアチブ、ガイド、 } \\
\text { ガイドライン }\end{array}$ \\
\hline \multirow[t]{2}{*}{ Sports } & $\begin{array}{l}\text { Events, objects, and place for } \\
\text { sports }\end{array}$ & Olympic, ball & オリンピック、ボール \\
\hline & Types of sports & soccer & サッカー \\
\hline \multirow[t]{2}{*}{ Vehicle } & Parts or types of vehicles & engine, car & エンジン、カー \\
\hline & $\begin{array}{l}\text { Operation or operator of } \\
\text { vehicles }\end{array}$ & driver & ドライバー \\
\hline
\end{tabular}


Table 10: Two non-theme-based semantic categories, their operational definitions, and example ELWs

\begin{tabular}{|c|c|c|c|}
\hline Category & Operational definitions & Example ELWs & Katakana form \\
\hline $\begin{array}{l}\text { General } \\
\text { Meaning }\end{array}$ & $\begin{array}{l}\text { Words that } \\
\text { 1) Belong to none of the } \\
\text { theme-based categories or } \\
\text { more than one category AND } \\
\text { 2) Refer to one general } \\
\text { meaning regardless of the } \\
\text { context }\end{array}$ & $\begin{array}{l}\text { answer, advice, } \\
\text { error, OK, up, and, } \\
\text { in, or, my }\end{array}$ & $\begin{array}{l}\text { アンサー、アドバイス、 } \\
\text { エラー、オーケー、 } \\
\text { アップ、アンド、イン、 } \\
\text { オア, マイ }\end{array}$ \\
\hline $\begin{array}{l}\text { Multiple } \\
\text { Meanings }\end{array}$ & $\begin{array}{l}\text { Words that } \\
\text { 1) Belong to none of the } \\
\text { theme-based categories or } \\
\text { more than one category } \underline{\text { AND }} \\
\text { 2) Convey different meanings } \\
\text { depending on the context }\end{array}$ & $\begin{array}{l}\text { window, green, } \\
\text { sheet, soft }\end{array}$ & $\begin{array}{l}\text { アルバム、ウィンドウ、 } \\
\text { グリーン、シート、ソフト }\end{array}$ \\
\hline
\end{tabular}

Overall distribution of semantic categories. Overall, there was a high

concentration of ELWs in Multiple Meanings, General Meaning, and Science \&

Technology, both in terms of the number of ELWs and the frequency (Table 11). These

three categories alone comprised approximately $60 \%$ of the occurrences and $55 \%$ of the

individual ELWs. The rest of the categories comprised less than $10 \%$ of the overall

frequency, although some of them were higher in certain registers.

Table 11: Overall distribution of semantic categories in the order of frequency

\begin{tabular}{|l|r|r|r|r|}
\hline \multicolumn{1}{|c|}{ Semantic category } & \# of ELWs & \multicolumn{1}{c|}{$\%$} & \multicolumn{1}{c|}{ Frequency } \\
\hline Multiple Meanings & 60 & $18 \%$ & $2,393 \mathrm{M}$ & $24 \%$ \\
\hline General Meaning & 85 & $25 \%$ & $2,338 / \mathrm{M}$ & $24 \%$ \\
\hline Science \& Technology & 40 & $12 \%$ & $1,277 / \mathrm{M}$ & $13 \%$ \\
\hline Measurements \& Units & 13 & $4 \%$ & $881 / \mathrm{M}$ & $9 \%$ \\
\hline Economy \& Business & 23 & $7 \%$ & $631 / \mathrm{M}$ & $6 \%$ \\
\hline Media \& Entertainment & 16 & $5 \%$ & $388 / \mathrm{M}$ & $4 \%$ \\
\hline Building \& Furniture & 8 & $2 \%$ & $300 / \mathrm{M}$ & $3 \%$ \\
\hline Social \& Public Life & 28 & $8 \%$ & $275 / \mathrm{M}$ & $3 \%$ \\
\hline Dining \& Food & 14 & $4 \%$ & $267 / \mathrm{M}$ & $3 \%$ \\
\hline Material \& Substance & 11 & $3 \%$ & $216 / \mathrm{M}$ & $2 \%$ \\
\hline Vehicle & 8 & $2 \%$ & $191 / \mathrm{M}$ & $2 \%$ \\
\hline Medical, Health \& Beauty & 9 & $3 \%$ & $184 / \mathrm{M}$ & $2 \%$ \\
\hline Personal \& Family Life & 11 & $3 \%$ & $158 / \mathrm{M}$ & $2 \%$ \\
\hline Sports & 7 & $1 \%$ & $143 / \mathrm{M}$ & $1 \%$ \\
\hline Numeral \& Math & 338 & $2 \%$ & $135 / \mathrm{M}$ & $1 \%$ \\
\hline Total & & $100 \%$ & $9,778 / \mathrm{M}$ & $100 \%$ \\
\hline
\end{tabular}


Distributions of semantic categories within registers. Table 12 presents the semantic categories that comprised $5 \%$ or more of the occurrences in at least one of the registers. Categories that did not comprise 5\% were grouped together as "Other." In addition, categories over 1,000/M are bolded as a frequent category.

Table 12: Distribution of semantic categories per register

\begin{tabular}{|c|c|c|c|c|c|c|}
\hline & \multicolumn{2}{|c|}{ White papers } & \multicolumn{2}{|c|}{ Books } & \multicolumn{2}{|c|}{ Internet texts } \\
\hline & $\begin{array}{c}\text { \# of } \\
\text { ELWs }\end{array}$ & Frequency & $\begin{array}{c}\text { \# of } \\
\text { ELWs }\end{array}$ & Frequency & $\begin{array}{c}\text { \# of } \\
\text { ELWs }\end{array}$ & Frequency \\
\hline $\begin{array}{l}\text { Multiple } \\
\text { Meanings }\end{array}$ & $\begin{array}{r}25 \\
(20 \%)\end{array}$ & $\begin{array}{r}3494 / M \\
(24 \%)\end{array}$ & $\begin{array}{r}23 \\
(22 \%)\end{array}$ & $\begin{array}{r}1670 / M \\
(27 \%)\end{array}$ & $\begin{array}{r}51 \\
(20 \%)\end{array}$ & $\begin{array}{r}3973 / M \\
(22 \%)\end{array}$ \\
\hline $\begin{array}{l}\text { General } \\
\text { Meaning }\end{array}$ & $\begin{array}{r}25 \\
(20 \%)\end{array}$ & $\begin{array}{r}2382 / M \\
(17 \%)\end{array}$ & $\begin{array}{r}30 \\
(28 \%)\end{array}$ & $\begin{array}{r}1541 / M \\
(25 \%)\end{array}$ & $\begin{array}{r}72 \\
(28 \%)\end{array}$ & $\begin{array}{r}4252 / \mathrm{M} \\
(24 \%)\end{array}$ \\
\hline $\begin{array}{l}\text { Science \& } \\
\text { Technology }\end{array}$ & $\begin{array}{r}18 \\
(14 \%)\end{array}$ & $\begin{array}{r}1490 / M \\
(10 \%)\end{array}$ & $\begin{array}{r}7 \\
(7 \%)\end{array}$ & $\begin{array}{r}381 / \mathrm{M} \\
(6 \%)\end{array}$ & $\begin{array}{r}31 \\
(12 \%)\end{array}$ & $\begin{array}{r}3411 / M \\
(19 \%)\end{array}$ \\
\hline $\begin{array}{l}\text { Measurement } \\
\& \text { unit }\end{array}$ & $\begin{array}{r}7 \\
(5 \%)\end{array}$ & $\begin{array}{r}3294 / M \\
(23 \%)\end{array}$ & $\begin{array}{r}7 \\
(7 \%)\end{array}$ & $\begin{array}{l}701 / \mathrm{M} \\
(12 \%)\end{array}$ & $\begin{array}{r}11 \\
(4 \%)\end{array}$ & $\begin{array}{r}935 / \mathrm{M} \\
(5 \%)\end{array}$ \\
\hline $\begin{array}{l}\text { Economy \& } \\
\text { business }\end{array}$ & $12(9 \%)$ & $\begin{array}{r}871 / \mathrm{M} \\
(6 \%)\end{array}$ & $\begin{array}{r}6 \\
(6 \%)\end{array}$ & $\begin{array}{r}377 / \mathrm{M} \\
(6 \%)\end{array}$ & $\begin{array}{r}14 \\
(6 \%)\end{array}$ & $\begin{array}{r}1205 / \mathrm{M} \\
(7 \%)\end{array}$ \\
\hline $\begin{array}{l}\text { Social \& } \\
\text { Public Life }\end{array}$ & $\begin{array}{r}23 \\
(18 \%)\end{array}$ & $\begin{array}{r}1779 / \mathrm{M} \\
(12 \%)\end{array}$ & $\begin{array}{r}5 \\
(5 \%)\end{array}$ & $\begin{array}{r}201 / \mathrm{M} \\
(3 \%)\end{array}$ & $\begin{array}{r}5 \\
(2 \%)\end{array}$ & $\begin{array}{r}217 / \mathrm{M} \\
(1 \%)\end{array}$ \\
\hline $\begin{array}{l}\text { Media \& } \\
\text { Entertainment }\end{array}$ & $3(2 \%)$ & $\begin{array}{r}123 / \mathrm{M} \\
(1 \%)\end{array}$ & $\begin{array}{r}3 \\
(3 \%)\end{array}$ & $\begin{array}{r}131 / \mathrm{M} \\
(2 \%)\end{array}$ & $\begin{array}{r}15 \\
(6 \%)\end{array}$ & $\begin{array}{r}1054 / \mathrm{M} \\
(6 \%)\end{array}$ \\
\hline $\begin{array}{l}\text { Building \& } \\
\text { Furniture }\end{array}$ & $2(2 \%)$ & $\begin{array}{r}121 / \mathrm{M} \\
(1 \%)\end{array}$ & $\begin{array}{r}7 \\
(7 \%)\end{array}$ & $\begin{array}{r}333 / \mathrm{M} \\
(5 \%)\end{array}$ & $\begin{array}{r}4 \\
(2 \%)\end{array}$ & $\begin{array}{r}249 / \mathrm{M} \\
(1 \%)\end{array}$ \\
\hline Other & $\begin{array}{r}13 \\
(10 \%)\end{array}$ & $\begin{array}{r}723 / \mathrm{M} \\
(6 \%)\end{array}$ & $\begin{array}{r}18 \\
(15 \%)\end{array}$ & $\begin{array}{l}729 / \mathrm{M} \\
(14 \%)\end{array}$ & $\begin{array}{r}51 \\
(20 \%)\end{array}$ & $\begin{array}{r}2752 / \mathrm{M} \\
(15 \%)\end{array}$ \\
\hline
\end{tabular}

There were both similarities and differences in the distributions of the semantic categories among the three registers. As for similarities, Multiple Meanings and General Meaning ELWs were consistently frequent in all registers. Science \& Technology was also frequent in white papers $(1,490 / \mathrm{M})$ and in internet texts $(3,411 / \mathrm{M})$. As for differences, some categories were frequent only in certain register, but not in others, such as Measurements \& Units, which had a high frequency in white papers (3,294/M), but was much less frequent in books and internet texts. Similarly, Social \& Public Life was exclusively frequent in white papers, and Economy \& Business and Media \& Entertainment were exclusively frequent in internet texts. For books, there was no other 
category above 1,000/M, which indicated that high-frequency ELWs in books are relatively neutral when it comes to semantic category.

Semantic categories and the types of borrowing. Three registers had almost identical patterns with respect to the distribution of the types of borrowing within a semantic category, except for Multiple Meanings. Figure 8 illustrates the proportions of the types of borrowing in Multiple Meanings, General Meaning, Science \& Technology, and Social \& Public Life.

As shown in Figure 8, the proportions of the types of borrowing in the three registers were very similar for General Meaning, in which almost all occurrences were core borrowings (e.g. system, level, type, group); Science \& Technology, in which the vast majority was cultural borrowing (e.g. mail, television, personal computer); and Social \& Public Life, in which the vast majority was core borrowing (e.g. message, communication, rule, needs). However, there were noticeable variations for Multiple Meanings. In white papers, the majority (52\%) of Multiple Meanings ELWs were core borrowings, such as center, which could refer to either the central part of something (中 心, chuushin) or a place for gathering ( 会館, ～kaikan). However, core borrowings were less dominant in books (41\%) and in internet texts (29\%). Instead, books and internet texts contained more core/cultural borrowings (e.g. key, card, address) and cultural borrowing (e.g. cream, button). 
Figure 8: Proportions of the types of borrowing in major semantic categories

Multiple Meanings (per 1M)

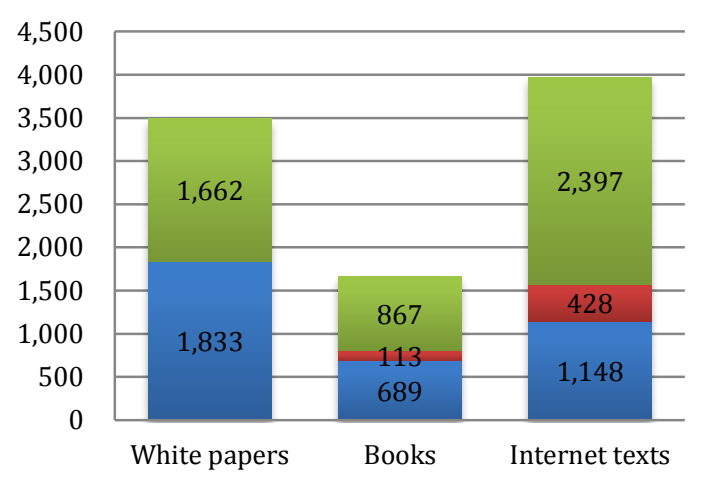

Core Cultural $\square$ Core/Cultural Core-Western

Science \& Technology (per 1M)

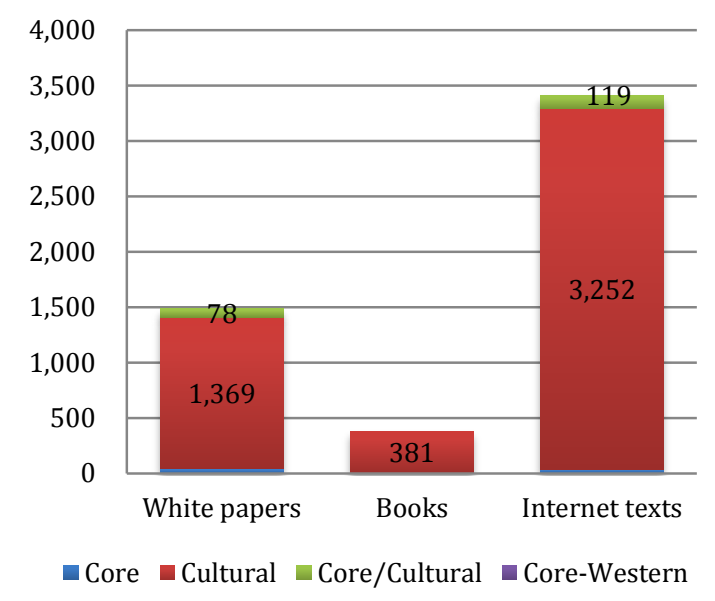

General Meaning (per 1M)

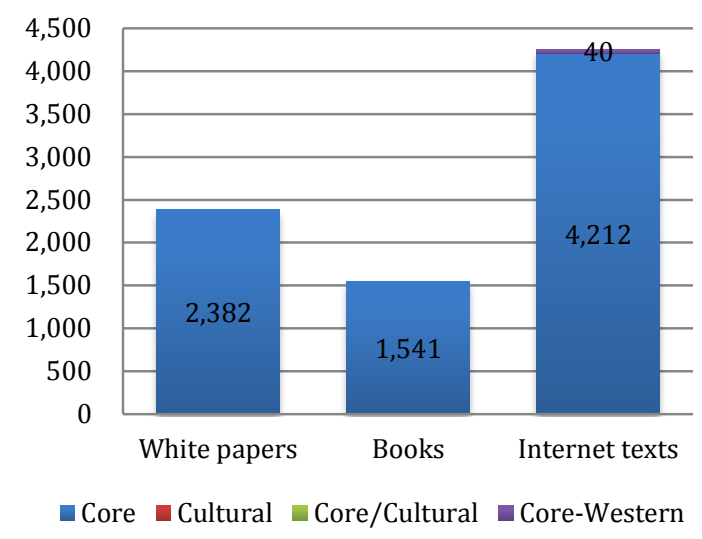

Social \& Public Life (per 1M)

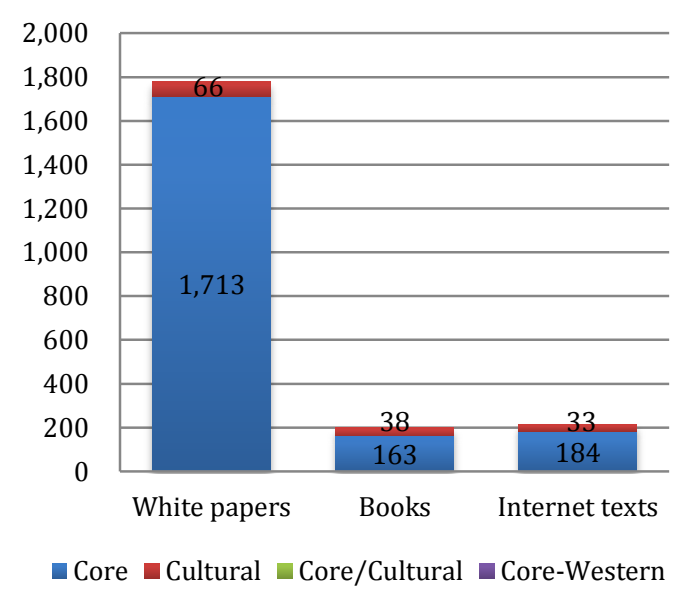

Register characteristics: White papers. As shown in Table 12, the most common category for white papers was Multiple Meanings (3,494/M), followed by Measurements \& Units (3,294/M), General Meaning (2,382/M), Social \& Public Life $(1,779 / \mathrm{M})$, and Science \& Technology $(1,490 / \mathrm{M})$.

One of the unique aspects of white papers was that it had exceptionally high frequencies for Measurements \& Units (3,294/M) and Social \& Public Life (1,779/M). I found that the high frequency for Measurements \& Units was due to one ELW, percentage $(2,841 / \mathrm{M})$, which alone accounted for nearly $20 \%$ of the overall frequency. 
Such frequent use of percent is most likely due to the reporting nature of white papers, which often includes descriptions of data, such as demographic, budget, and results of assessments, as in this example:

...農地費が最も大きな割合（5 2．２％）を占め、以下、林業費（2 2 . $9 \%$ ）、水産業費（１２．７％）、農業費（１０．０％）の順となってい る。

...the farmland expenses accounted for the largest proportion (52.2\%), followed by forestry expenses $(22.9 \%)$, fishery expenses $(12.7 \%)$, and agriculture expenses $(10.0 \%)$.

Similarly, the frequent use of ELWs in Social \& Public Life reflected the nature of white papers, which is to report social and public affairs to the citizens. For example, initiative and volunteer were some of the frequent Social \& Public Life ELWs in white papers:

...地域のイニシアティブの下で...構成される ...システム

... a system...that is developed... under the $\underline{\underline{\text { initiative }}}$ of the local municipalities...

...大規模災害等が発生した場合、県とボランティア団体などが連携して ...「神奈川県災害救援ボランティア支援センター」を設置することとさ れており ...

....in the case of large-scale disaster, it has been decided that the prefecture and volunteer organizations are to collaborate...to set up the "Center for Disaster Relief Volunteer Support in Kanagawa Prefecture “...

I found another interesting aspect of white papers in the Multiple Meanings category. As mentioned earlier, Multiple Meaning ELWs potentially refer to multiple different meanings depending on the context. However, I found that many of the Multiple Meanings ELWs in white papers typically referred to only one of the meanings. For instance, the ELW center in white papers almost exclusively referred to an organization 
or facility that offers some type of public service, rather than something located in the middle, as in:

障害者職業センター 'center for handicapped workers’

ボランティアセンター,volunteer center’

アジア防災センター,Asian Disaster Reduction Center'

Another example of Multiple Meaning ELW being used for only one of the meanings is the ELW service, which in Japanese could potentially imply "to offer (something) for free”, as in“ケーキをサービスする” (,to service [offer] a piece of cake [for free]’).

However, service in white papers only referred to public services offered by companies or institutions, such as: 介護サービス (,nursing-care services'); 医療福祉サービス (,medical welfare services); and 子育て支援サービス (,parenting support services'). ). In addition, the Multiple Meanings ELWs barrier and free were almost always used in terms of accessibility, as in “交通バリア・フリー法” (,Barrier-Free Transportation Act').

In sum, the ELWs in white papers reflected the communicative purpose of white papers, as seen in the frequent use of ELWs in Measurements \& Units (e.g. percent) and Social \& Public Life, as well as the selective use of Multiple Meanings ELWs.

Register characteristics: Books. The most common semantic categories for books were Multiple Meanings (1,670/M) and General Meaning (1,541/M). Other semantic categories in books were relatively infrequent, occurring at 700/M or lower.

Unlike the Multiple Meaning ELWs in white papers that tended to be used only in specific terms (e.g. service, barrier, free), I found that the Multiple Meanings ELWs in 
books were used for diverse meanings. For example, service in books was used in the following ways:

医療サービス „,medical services”

ビール一杯开ービスされました,(I) received a service of a glass of beer (for free)'

In the first example, service is used to refer to services offered by organizations or companies, similar to the ones in white papers. In the second example, service is referring to the act of "offering something for free," with the addition of the Japanese verb suru (,to do').

As mentioned earlier, the vast majority of the ELWs in books were also found in other registers. In fact, of the 106 ELWs, only 11 ELWs were unique to books: ion, Islam, member, staff, pattern, table, house, bed, hormone, restaurant, and wine. This extremely high rate of overlap with other registers seems to indicate that the ELWs found in books are not specific to the book register, but instead very common across the three registers. The fact that the ELWs in books were common across the three registers and that nearly half of them were non-theme-specific suggests that books tended to contain ELWs that are broadly used in a variety of situations. This broadness contrasts with other two registers, which had more specific uses for ELWs than white papers. 
Register characteristics: Internet texts. For internet texts, the most common semantic category was General Meaning (4,252/M), followed by Multiple Meanings $(3,973 / \mathrm{M})$ and Science \& Technology $(3,411 / \mathrm{M})$.

The most characteristic aspect of General Meaning ELWs in internet texts was the frequent appearances of function words, such as prepositions (e.g. to, off, by), pronouns (e.g. $m y$ ), and conjunctions (e.g. or, and). Typically, these function words appeared in English phrases, such as 'oh my god' and ,in my heart,' which were often direct quotes from an English song or movie. However, there were also plenty of cases where ELWs were used in a Japanese phrase, replacing their Japanese equivalents, for example:

日曜日 or 月曜日 (Sunday or Monday)

In this example, the Japanese equivalent of the ELW,or' is か (ka), which, if used, would be in the exact same location as ,or' as in 日曜日か月曜日. The precise motivation for choosing to use the ELW rather than the Japanese word is unknown, but some possible reasons might be that the ELW is becoming so common that the writer felt free to choose to use it, or that he or she wanted to sound "western." Nevertheless, such usages of ELWs were only found in internet texts.

The ELWs in Science \& Technology in internet texts were predominantly related to information technology, such as pasokon (perso[nal] com[puter]), mail, site, internet, net, click, install, and download. Other Science \& Technology ELWs were mostly related to entertainment, such as television, radio, video, and camera, for example:

液晶テレビとプラズマテレビの違いを教えてください。 What is the difference between LCD televi(sion) and plasma televi(sion) (?) パソコンから携帯にメール送信ができません。 
I am unable to send $\underline{\text { mail }}$ from a pasokon to a cell phone.

ダウンロードというところからクリックすれば、ダウンロードできます。 „If you click where it says download, you can download (it).'

As can be observed in the examples above, I found that Science \& Technology ELWs in internet texts tended to co-occur in the same sentence, which contributed to the high frequency of this semantic category. A possible explanation for the co-occurrences is that Science \& Technology ELWs, most of which were related to newly introduced information technology, required other ELWs to describe the concepts related to them.

Section summary: Semantic categories. So far, I have discussed the major characteristics of the common semantic categories in each register: white papers, books, and internet texts. I found that Multiple Meanings and General Meaning had the highest percentage of the high-frequency ELW occurrences in all three registers. In addition to these two categories, white papers also contained many ELWs in Measurements \& Units and Social \& Public Life, which were used to describe social and public matters. I also found that Science \& Technology ELWs were particularly common in internet texts, and they were mostly related to computer and information technology. Internet texts also exhibited nontraditional use of function word ELWs. In addition, I found that ELWs in books were the least context-specific, and that most of them were commonly used in all three registers. Lastly, the types of borrowing in the semantic categories were fairly identical across registers, except for Multiple Meanings, which tended to include more elements of cultural borrowing in books and internet texts than in white papers. 


\section{Comprehension Rates of the High-frequency ELWs}

This section reports the rates at which people over 60 years old comprehended the high-frequency ELWs based on the findings from NINJAL's Language Attitude and Pervasion Survey (NINJAL 2006). The results will then be compared with the register characteristics previously discussed, which will answer the second research question, how do the comprehension rates of high-frequency ELWs compare across registers?

Of the original 398 loan words surveyed in the NINJAL study, I found 52 ELWs that had been identified as high-frequency ELWs in this study. In the 52 ELWs, three types of borrowings (core, cultural, core/cultural) and seven semantic categories (Multiple Meanings; General Meaning; Science \& Technology; Social \& Public Life; Economy \& Business; Media \& Entertainment; Medical, Health \& Beauty) were represented. Table 13 presents the 52 high-frequency ELWs, their types of borrowing, semantic categories, and the comprehension rates based on the NINJAL survey.

Overall comprehension. As shown in Table 13, the comprehension rates of the 52 high-frequency ELWs for people over 60 years or above $(60+)$ ranged from $1.1 \%$ (literacy) to $82.9 \%$ (stress) with the average of $43.9 \%$. The average difference between the two groups was $19.5 \%$; that is, nearly $20 \%$ more people over 60 years old were likely to have difficulty comprehending high-frequency ELWs than the overall group. The differences in comprehension rates between the two groups were generally greater for ELWs with lower comprehension rates for the older age group. 
Table 13: High-frequency ELWs Comprehension List based on Language Attitude and Pervasion Survey (NINJAL 2006)

\begin{tabular}{|c|c|c|c|c|c|c|}
\hline Japanese & English & $\begin{array}{l}\text { Semantic } \\
\text { category }\end{array}$ & Loan Type & $\begin{array}{c}\text { Overall } \\
(\%)\end{array}$ & $\begin{array}{l}60+ \\
(\%)\end{array}$ & $\begin{array}{c}\text { Difference } \\
(\%)\end{array}$ \\
\hline ストレス & stress & $\begin{array}{l}\text { Medical, Health } \\
\text { \& Beauty }\end{array}$ & Core & 92.6 & 82.9 & 9.7 \\
\hline リサイクル & recycle & $\begin{array}{l}\text { Social \& Public } \\
\text { Life }\end{array}$ & Core & 91.1 & 82.8 & 8.3 \\
\hline トラブル & trouble & General & Core & 92.3 & 81.1 & 11.2 \\
\hline ボランティア & volunteer & $\begin{array}{l}\text { Social \& Public } \\
\text { Life }\end{array}$ & Core & 90.8 & 80.2 & 10.6 \\
\hline リハビリ & rehabili(tation) & $\begin{array}{l}\text { Medical, Health } \\
\& \text { Beauty }\end{array}$ & Core & 87.3 & 79.6 & 7.7 \\
\hline ルール & rule & $\begin{array}{l}\text { Social \& Public } \\
\text { Life }\end{array}$ & Core & 90.1 & 77.0 & 13.1 \\
\hline キャンセル & cancel & General & Core & 88.7 & 75.2 & 13.5 \\
\hline テーマ & theme & General & Core & 88.2 & 74.9 & 13.3 \\
\hline メッセージ & message & $\begin{array}{l}\text { Social \& Public } \\
\text { Life }\end{array}$ & Core & 88.4 & 74.2 & 14.2 \\
\hline スタッフ & staff & General & Core & 83.4 & 67.8 & 15.6 \\
\hline ネットワーク & network & Multiple & Core/Cultural & 81.4 & 63.9 & 17.5 \\
\hline イベント & event & $\begin{array}{l}\text { Social \& Public } \\
\text { Life }\end{array}$ & Core & 82.2 & 63.5 & 18.7 \\
\hline メリット & merit & General & Core & 82.7 & 61.1 & 21.6 \\
\hline プロジェクト & project & General & Core & 78.2 & 60.3 & 17.9 \\
\hline ピーク & peak & General & Core & 77.4 & 59.7 & 17.7 \\
\hline インターネット & internet & $\begin{array}{l}\text { Science \& } \\
\text { Technology }\end{array}$ & Cultural & 78.3 & 58.7 & 19.6 \\
\hline ケア & care & $\begin{array}{l}\text { Medical, Health } \\
\text { \& Beauty }\end{array}$ & Core & 75.6 & 58.1 & 17.5 \\
\hline クリア & clear & Multiple & Core & 79.1 & 58.0 & 21.1 \\
\hline コスト & cost & $\begin{array}{l}\text { Economy \& } \\
\text { business }\end{array}$ & Core & 74.8 & 57.5 & 17.3 \\
\hline ハイテク & high-tech & $\begin{array}{l}\text { Science \& } \\
\text { Technology }\end{array}$ & Cultural & 77.1 & 55.4 & 21.7 \\
\hline リスク & risk & General & Core & 71.5 & 49.7 & 21.8 \\
\hline シンポジウム & symposium & $\begin{array}{l}\text { Social \& Public } \\
\text { Life }\end{array}$ & Core & 60.8 & 49.5 & 11.3 \\
\hline ガイドライン & guideline & $\begin{array}{l}\text { Social \& Public } \\
\text { Life }\end{array}$ & Core & 56.0 & 45.9 & 10.1 \\
\hline マニュアル & manual & Multiple & Core/Cultural & 74.4 & 44.0 & 30.4 \\
\hline ニーズ & needs & $\begin{array}{l}\text { Social \& Public } \\
\text { Life }\end{array}$ & Core & 64.9 & 43.6 & 21.3 \\
\hline デジタル & digital & $\begin{array}{l}\text { Science \& } \\
\text { Technology }\end{array}$ & Cultural & 68.1 & 42.8 & 25.3 \\
\hline パートナーシップ & partnership & $\begin{array}{l}\text { Social \& Public } \\
\text { Life }\end{array}$ & Core & 55.0 & 41.3 & 13.7 \\
\hline データ & data & Multiple & Core/Cultural & 65.5 & 41.2 & 24.3 \\
\hline コミュニティー & community & $\begin{array}{l}\text { Social \& Public } \\
\text { Life }\end{array}$ & Core & 57.7 & 40.1 & 17.6 \\
\hline ユーザー & user & General & Core & 65.4 & 39.1 & 26.3 \\
\hline
\end{tabular}




\begin{tabular}{|c|c|c|c|c|c|c|}
\hline マネージメント & management & General & Core & 60.0 & 37.4 & 22.6 \\
\hline メディア & media & $\begin{array}{l}\text { Media \& } \\
\text { Entertainment }\end{array}$ & Core & 63.2 & 35.8 & 27.4 \\
\hline セキュリティー & security & General & Core & 65.6 & 35.8 & 29.8 \\
\hline シェア & share & $\begin{array}{l}\text { Economy \& } \\
\text { business }\end{array}$ & Core/Cultural & 50.9 & 35.2 & 15.7 \\
\hline プログラム & program & Multiple & Core/Cultural & 61.7 & 31.6 & 30.1 \\
\hline フォーラム & forum & $\begin{array}{l}\text { Social \& Public } \\
\text { Life }\end{array}$ & Core & 46.8 & 31.6 & 15.2 \\
\hline アクセス & access & Multiple & Core/Cultural & 57.7 & 31.3 & 26.4 \\
\hline ソフト & soft & Multiple & Core/Cultural & 58.6 & 30.4 & 28.2 \\
\hline ハード & hard & Multiple & Core/Cultural & 53.4 & 25.1 & 28.3 \\
\hline ネット & net & $\begin{array}{l}\text { Science \& } \\
\text { Technology }\end{array}$ & Cultural & 60.3 & 23.8 & 36.5 \\
\hline ディスク & disk & $\begin{array}{l}\text { Science \& } \\
\text { Technology }\end{array}$ & Cultural & 55.5 & 22.8 & 32.7 \\
\hline データーベース & database & $\begin{array}{l}\text { Science \& } \\
\text { Technology }\end{array}$ & Cultural & 45.6 & 21.5 & 24.1 \\
\hline ツール & tool & Multiple & Core/Cultural & 40.9 & 18.7 & 22.2 \\
\hline グローバル & global & $\begin{array}{l}\text { Social \& Public } \\
\text { Life }\end{array}$ & Core & 41.3 & 18.7 & 22.6 \\
\hline プロバイダー & provider & $\begin{array}{l}\text { Science \& } \\
\text { Technology }\end{array}$ & Cultural & 40.6 & 15.2 & 25.4 \\
\hline イニシアチブ & initiative & $\begin{array}{l}\text { Social \& Public } \\
\text { Life }\end{array}$ & Core & 27.4 & 15.0 & 12.4 \\
\hline リンク & link & $\begin{array}{l}\text { Science \& } \\
\text { Technology }\end{array}$ & Core/Cultural & 38.5 & 10.4 & 28.1 \\
\hline バイオマス & biomass & $\begin{array}{l}\text { Science \& } \\
\text { Technology }\end{array}$ & Cultural & 9.1 & 8.9 & 0.2 \\
\hline コンテンツ & contents & $\begin{array}{l}\text { Science \& } \\
\text { Technology }\end{array}$ & Core/Cultural & 23.0 & 8.8 & 14.2 \\
\hline ダウンロード & download & $\begin{array}{l}\text { Science \& } \\
\text { Technology }\end{array}$ & Cultural & 40.6 & 8.2 & 32.4 \\
\hline サイト & site & $\begin{array}{l}\text { Science \& } \\
\text { Technology }\end{array}$ & Cultural & 34.4 & 7.8 & 26.6 \\
\hline リテラシー & literacy & General & Core & 6.3 & 1.1 & 5.2 \\
\hline \multicolumn{4}{|c|}{ Average } & 63.5 & 43.9 & $\mathbf{1 9 . 5}$ \\
\hline
\end{tabular}


Comprehension by the types of borrowing. In terms of types of borrowing, I found that the best comprehended ELWs were core borrowings, followed by core/cultural, and cultural (Figure 9). The difference between $60+$ and the overall age group was the greatest for cultural borrowings, followed by core/cultural, and core.

Figure 9: Comprehension rates by the type of borrowings

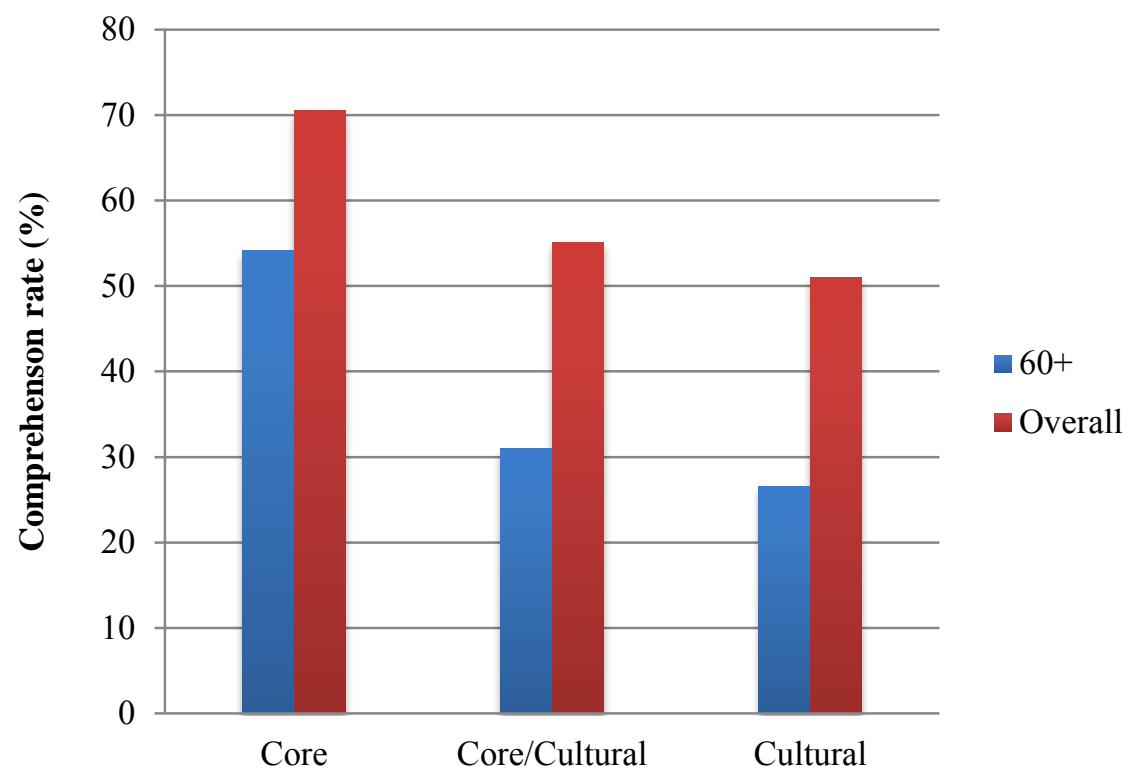

One possible explanation for the low comprehension rate for cultural borrowings is the complex process of learning cultural borrowing ELWs. In order to understand cultural borrowing ELWs, one must first learn the content of the referent itself before being able to connect the meaning and the word, which is quite different from applying prior knowledge about the referent to make sense of the ELW, as would be the case for core borrowings. For example, if one does not know what the ELW database means, he or she must first learn the meaning of database, then remember the new vocabulary デー タベース (deetabeesu). On the other hand, the ELW trouble is a core borrowing because the general concept of trouble already existed in Japanese (e.g. 難儀, nangi) before the 
ELW was introduced. Thus, all that is necessary is to remember the new vocabulary トラ ブル (toraburu) and to link it to the core meaning of 難儀. Therefore, because it takes more learning to comprehend cultural borrowing ELWs, it is understandable that the comprehension rate was lower for cultural borrowings than core borrowings.

Comprehension of core/cultural borrowing ELWs has its own complex process as well. For example, the ELW network (ネットワーク, nettowaaku) is a core/cultural borrowing that can refer to both a network of human connections (core) and/or a digital network (cultural), which are distantly related but are used in contrasting contexts. Because the concept of network, as in human connections, already exists in Japanese, one must learn the ELW in two different ways: one as a core borrowing by applying the existing knowledge and then remembering the word ネットワーク, and the other as a cultural borrowing by first learning the concept and remembering that it is called ネット ワーク. Finally, they would need to store the ELW as a polyseme in their mental lexicon. Thus, comprehension rates for ELWs seem to be influenced by the existence or the absence of prior knowledge about the word and the process of learning the ELW. The fact that the difference between the two age groups was greater for cultural and core/cultural borrowings than core borrowings suggests that people over 60 years old were less likely to have learned the concepts or objects that cultural ELWs refer to.

Comprehension by the semantic category. In addition to the process of learning mentioned above, the amount of exposure to and motivation for learning new ELWs likely influence one's comprehension of ELWs. As previously discussed, the semantic categories represent the contexts in which the ELWs are likely used; therefore, the 
comprehension differences may be in part due to the exposure to the context or lack thereof. For instance, if one does not use a computer, there are little opportunities and/or motivation to learn the ELW download. Thus, a comparison of comprehension rates by the semantic category may indicate the varying amount of exposure that people over 60 years old have with certain contexts.

Given the small number of ELWs, it was not possible to obtain sizable samples for each semantic category. Media \& Entertainment and Economy \& Business only had one and two ELWs, respectively. Because they were too small to suggest any patterns for the category, I excluded these two categories from this part of analysis. Table 14 presents the ELWs in the remaining semantic categories: Medical, Health \& Beauty; Multiple Meanings; General Meaning; Social \& Public Life; and Science \& Technology.

Table 14: High-frequency ELW comprehension list by the semantic category

\begin{tabular}{|l|l|}
\hline \multicolumn{1}{|c|}{ Semantic category } & \multicolumn{1}{|c|}{ ELWs } \\
\hline $\begin{array}{l}\text { Medical, Health \& } \\
\text { Beauty }\end{array}$ & stress, rehabilitation, care \\
\hline Multiple Meanings & access, clear, data, hard. manual, network, program, soft, tool \\
\hline General Meaning & $\begin{array}{l}\text { cancel, literacy, management, merit, peak, project, risk, security, staff, } \\
\text { theme, trouble, user }\end{array}$ \\
\hline Social \& Public Life & $\begin{array}{l}\text { community, event, forum, global, guideline, initiative, message, needs, } \\
\text { partnership, recycle, rule, symposium, volunteer }\end{array}$ \\
\hline Science \& Technology & $\begin{array}{l}\text { biomass, contents, database, digital, disk, download, high-tech, internet, } \\
\text { link, net, provider, site }\end{array}$ \\
\hline
\end{tabular}

Figure 10 presents the average comprehension rates for the five semantic categories. For the 60+ group, the best comprehended semantic category was Medical, Health \& Beauty (73.5\%), followed by General Meaning (53.6\%), and Social \& Public Life (51\%). The lowest comprehension occurred in Science \& Technology (23.7\%), and Multiple Meanings (38.2\%). The difference of comprehension between the $60+$ group 
and the overall age group was the greatest in Multiple Meanings $(-25.4 \%)$, followed by Science \& Technology (-23.9\%).

Figure 10: Comprehension rates by the semantic categories

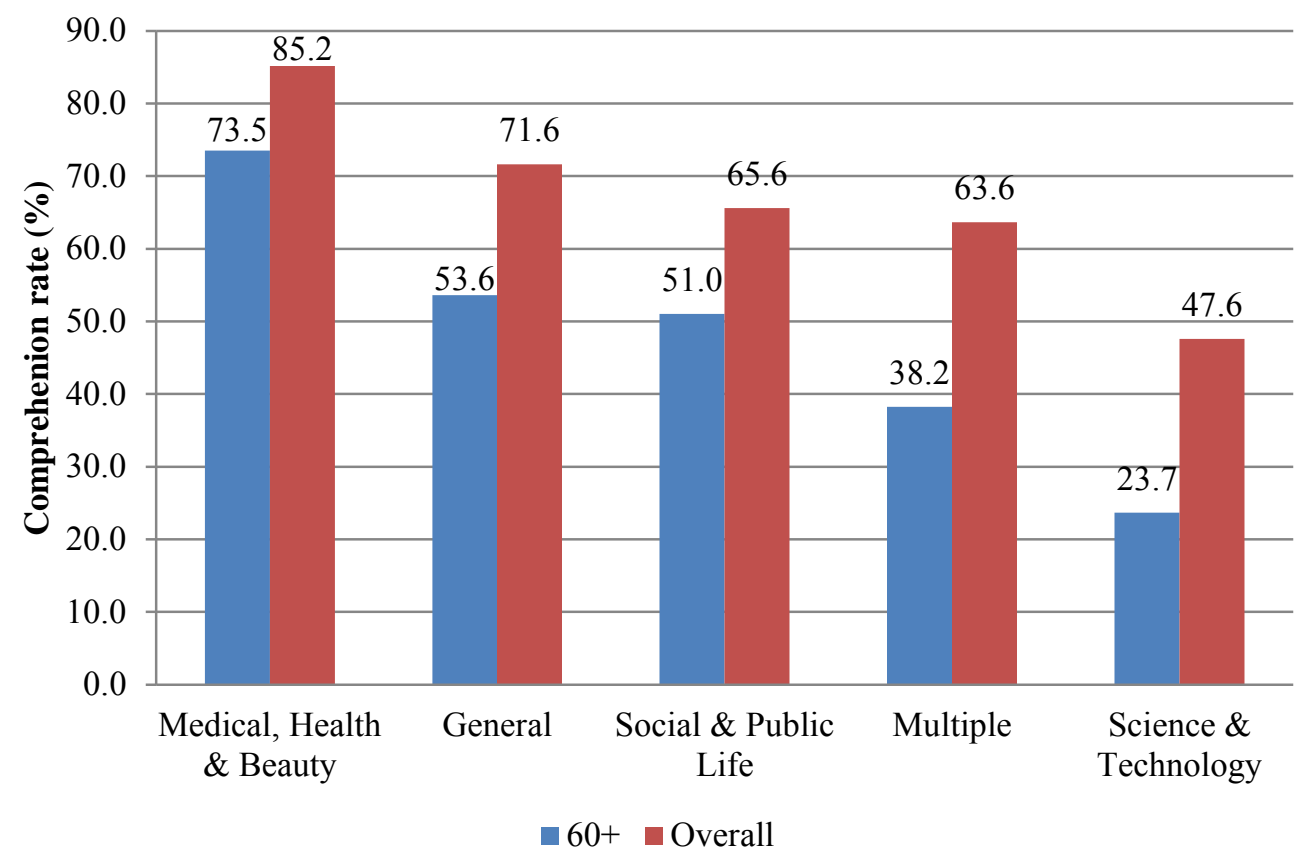

It makes sense that the Medical, Health \& Beauty category was best comprehended considering that the ELWs (stress, rehabilitation, care) were core borrowings and also because people are likely to have high exposure to situations related to health. Also, all of the ELWs in General Meaning and Social \& Public Life were core borrowings, which likely explains their relatively high comprehension rates. Particularly, the $60+$ group comprehended ELWs that are directly related to day-to-day life, such as trouble $(81.1 \%)$, recycle $(82.8 \%)$, and volunteer $(80.2 \%)$, much better than ELWs that are context-specific, such as forum (31.6\%), global (18.7\%), and initiative (15\%).

For Multiple Meanings, on the other hand, the vast majority of the ELWs were core/cultural borrowings: tool, hard, soft, access, program, data, manual, and network. The meanings on the cultural side of these ELWs were mostly related to computer 
technology, as in tool bar, hardware, and software. Similarly, the ELWs in Science \& Technology were also mostly computer/information technology related, such as contents, site, link, provider, download, database, disk, and net. Therefore, not only are these words cultural borrowings, they are also heavily context-laden, which means that people would need to be exposed to such contexts enough to learn these ELWs. Since computer technology is a relatively new aspect of one's day-to-day life experience, it makes sense that these ELWs were less comprehended than other semantic categories. In particular, the difference between the two groups were even greater for Multiple Meanings and Science \& Technology, which indicated that people over 60 years old are less familiar with technology related ELWs than the overall age group.

Section summary: comprehension rates and registers. In sum, based on the NINJAL survey results for the 52 high-frequency ELWs, I found that more than half of the people over 60 years old did not comprehend the high-frequency ELWs, which is astonishing. The results also indicated that comprehension rates are likely influenced by the types of borrowing and the semantic categories. The low comprehension of Science \& Technology ELWs indicated that people are most likely to encounter comprehension problems with internet texts because the frequent use of Science \& Technology ELWs was one of the characteristic features of internet texts. In addition, the finding that internet texts had the highest frequency of cultural borrowings in Multiple Meanings, which was one of the most dominant semantic groups in all of the registers, also pointed to the same conclusion that ELWs in internet texts would be most difficult to comprehend. 
The relatively low comprehension rates for ELWs in Social \& Public Life, which was uniquely frequent in white papers, indicated that ELWs in white papers were also difficult to comprehend. Especially, ones that are not directly related to one's day-to-day routine are likely to cause comprehension problem.

\section{Chapter Summary}

In this chapter, I have reported the overall frequencies and diversities of katakana words and high-frequency ELWs, and the attributes of high-frequency ELWs with regard to their types of borrowing and semantic categories in three distinct registers of Japanese written texts. I have also reported the comprehension rates for the high-frequency ELWs, with particular attention to those over 60 years old. These results provided answers the research questions of the study:

\section{RQ1.1: Frequencies and diversity of katakana words and high-frequency}

ELWs. The frequencies of both katakana words and high-frequency ELWs were highest in internet texts, followed by white papers and books. Meanwhile, white papers contained the most diverse group of katakana words and high-frequency ELWs.

RQ1.2: Types of borrowing of high-frequency ELWs. For all three registers, core borrowings were the most common type of borrowing, followed by cultural, core/cultural, and core-western.

RQ1.3: Semantic categories of high-frequency ELWs. For all three registers, Multiple Meanings and General Meaning were very common. In addition, Science \& Technology was common in white papers and internet texts. Social \& Public Life was also common in white papers, while Economy \& Business and Media \& Entertainment 
were common in internet texts. Books did not have any other semantic categories that were particularly frequent.

RQ 2. The study showed that more than $50 \%$ of the people over 60 years old do not comprehend the 52 high-frequency ELWs. Internet texts are likely to be the most problematic register, as it frequently includes ELWs related to Science \& Technology, which are least comprehended by people over 60 years old. In addition, white papers can also be problematic, especially when Social \& Public Life ELWs are used to describe concepts that are not directly related to the reader's day-to-day routine. Books are likely the least problematic register because the overall frequency of ELWs is much lower than in the other two registers, and also most of the ELWs are commonly used across registers, which suggests their stable status within the Japanese vocabulary. 


\section{Chapter 5}

\section{Conclusion}

In this study, I found that high-frequency ELWs in government white papers, books, and internet texts are similar with respect to the distribution of types of borrowing and the common dominant semantic categories. I also found that they are distinctly different in terms of the overall frequency and the distribution of non-dominant semantic categories. These differences projected varying degrees of hardship that people over 60 years old are likely to experience when reading texts in the three registers. Table 15 summarizes the results.

Table 15: Summary of study results

\begin{tabular}{|c|c|c|c|c|c|}
\hline & & $\begin{array}{c}\text { Govt. } \\
\text { white } \\
\text { papers }\end{array}$ & Books & $\begin{array}{l}\text { Internet } \\
\text { texts }\end{array}$ & Overall \\
\hline \multirow{10}{*}{$\begin{array}{l}\text { RQ } \\
1\end{array}$} & Katakana word frequency & $21,500 / \mathrm{M}$ & $20,400 / \mathrm{M}$ & $36,000 / \mathrm{M}$ & $24800 / \mathrm{M}$ \\
\hline & Katakana word types & 1,553 & 9,494 & 6,551 & 10,854 \\
\hline & Katakana words TTR & 0.087 & 0.037 & 0.035 & 0.023 \\
\hline & Frequency of High-freq. ELWs & $14,293 / \mathrm{M}$ & $6,072 / \mathrm{M}$ & $18,047 / \mathrm{M}$ & $9,778 / \mathrm{M}$ \\
\hline & High-freq. ELW types & 128 & 106 & 254 & 338 \\
\hline & High-freq. ELW TTR & 0.0108 & 0.0014 & 0.0027 & 0.0018 \\
\hline & $\begin{array}{l}\text { The most common type of borrowing } \\
\text { based on the number of occurrences }\end{array}$ & Core & Core & Core & Core \\
\hline & $\begin{array}{l}\text { The most common type of borrowing } \\
\text { based on the number of ELW types }\end{array}$ & Core & Core & Core & Core \\
\hline & $\begin{array}{l}\text { The most common semantic category } \\
\text { based on the frequency }\end{array}$ & Multiple & Multiple & General & Multiple \\
\hline & $\begin{array}{l}\text { The most common semantic category } \\
\text { based on the number of ELW types }\end{array}$ & $\begin{array}{l}\text { General \& } \\
\text { Multiple }\end{array}$ & General & General & General \\
\hline \multirow[t]{5}{*}{$\begin{array}{l}\mathbf{R Q} \\
2\end{array}$} & $\begin{array}{l}\text { Number of high-frequency ELWs } \\
\text { included in NINJAL survey }\end{array}$ & 40 & 17 & 26 & 55 \\
\hline & $\begin{array}{l}\text { Type of borrowing that received the } \\
\text { highest comprehension rate }\end{array}$ & Core & Core & Core & Core \\
\hline & $\begin{array}{l}\text { Type of borrowing that received the } \\
\text { lowest comprehension rate }\end{array}$ & Cultural & Core/Cult & Cultural & Cultural \\
\hline & $\begin{array}{l}\text { Best comprehended semantic } \\
\text { category }\end{array}$ & $\begin{array}{l}\text { Med, } \\
\text { Health, \& } \\
\text { Beauty }\end{array}$ & $\begin{array}{l}\text { Social \& } \\
\text { Public Life }\end{array}$ & $\begin{array}{l}\text { Med, } \\
\text { Health, \& } \\
\text { Beauty }\end{array}$ & $\begin{array}{l}\text { Med, } \\
\text { Health, \& } \\
\text { Beauty }\end{array}$ \\
\hline & $\begin{array}{l}\text { Least comprehended semantic } \\
\text { category }\end{array}$ & $\begin{array}{l}\text { Science \& } \\
\text { Tech }\end{array}$ & $\begin{array}{l}\text { Science \& } \\
\text { Tech }\end{array}$ & $\begin{array}{l}\text { Science \& } \\
\text { Tech }\end{array}$ & $\begin{array}{l}\text { Science \& } \\
\text { Tech }\end{array}$ \\
\hline
\end{tabular}




\section{Considering Previous Research}

The results of my study are similar to findings by Kiryuu (2007) in some ways. In her analysis of loan words in different sections of newspapers, Kiryuu found that the majority of loan words in sections with assigned topics, such as sports and entertainment, occurred only in that particular section (e.g. home team in sports, late show in entertainment). On the other hand, loan words in sections without a pre-assigned topic, such as front page and editorial sections were mostly section-free, that is, these loan words occurred across multiple sections. Similarly, for government white papers, whose topic areas are limited to public affairs, I found that $46 \%$ of the high-frequency ELWs were register-specific and most of them were related to public affairs (e.g. volunteer, recycle, terrorism). For books, on the other hand, whose topic areas are much broader than white papers, only $10 \%$ of the high-frequency ELWs were register-specific and the rest appeared in multiple registers. However, this pattern did not apply to internet texts, which had the broadest range of topics of all, but also had the highest percentage of register-specific high-frequency ELWs. Therefore, while there seems to be some kind of relationship between topic specificity and the use of topic-specific ELWs, register difference, rather than topics, appears to be a larger factor for the different patterns of ELW occurrences.

By adopting Biber and Conrad's functional interpretation approach (Biber \& Conrad, 2009), which takes situational features of the register to provide explanations for the linguistic features, I was able to identify a few features that may have contributed to the high frequency of ELWs in internet texts. One of the contrasting situational features among the registers is their production circumstances; while white papers and books 
require careful review and editing, internet texts, particularly texts in Yahoo! Chiebukuro, are usually written quickly with no editing.

Another contrasting situational feature is the authors' social accountabilities; while white papers and books have identifiable authors or agencies that are held accountable for the outcome of the texts, internet text authors are anonymous and have freedom to write anything they wish without any real-life consequences. Therefore, it seems reasonable to assume that authors of internet texts have the freedom to be creative in their language use, including ELWs.

Furthermore, the three registers most distinctly differed in their mediums of distribution and participants. While white papers and books are disseminated mostly in paper, and available for the general public, internet texts are available only on the Internet; hence, only those who are proficient users of computer technology can access them, which might explain why Science \& Technology ELWs were frequent.

\section{Implications}

It was especially clear from the study that people over 60 years old are much more likely to encounter comprehension problems with computer technology related ELWs than the younger generation would. The reason for this could be as simple as the fact that the younger generation is likely more exposed to technology than the older generation, or that the older generation's negative attitude towards the rise of technologydependent life style itself is preventing their acquisition of these ELWs. Nevertheless, the lack of knowledge of technology related ELWs could cause serious problems not only on communication level but also on functional level in contemporary Japan. For example, in an effort to promote online tax filing, the National Tax Agency distributed a flyer which I 
found on a local bus in Tokyo (Figure 11). In a form that mimics a website with a ,search' box with a cursor-like arrow next to it, the flyer contains eleven distinct ELWs: net, smart, homepage, corner, recycle, e-tax, IC, card, reader, writer, and speedy.

Considering that this was found on a local bus, it seems clear that the flyer was intended for the general public to see. Particularly, the top of the flyer reads, "netto de smaato!" (,smart [tax filing] on the net!'), which is a typical pattern of ELW incorporation into Japanese where ELWs are embedded in the Japanese syntax. However, based on the NINJAL survey (2006), the comprehension rates for the ELW net by people over 60 years old was merely $23 \%$, and the comprehension rate for smart is unknown. Thus, it is questionable whether people over 60 years old who look at the flyer would understand the main message of it at all.

Figure 11: A flyer promoting online tax filing, found on a local bus in Tokyo (photo taken by Horikawa, 2011)

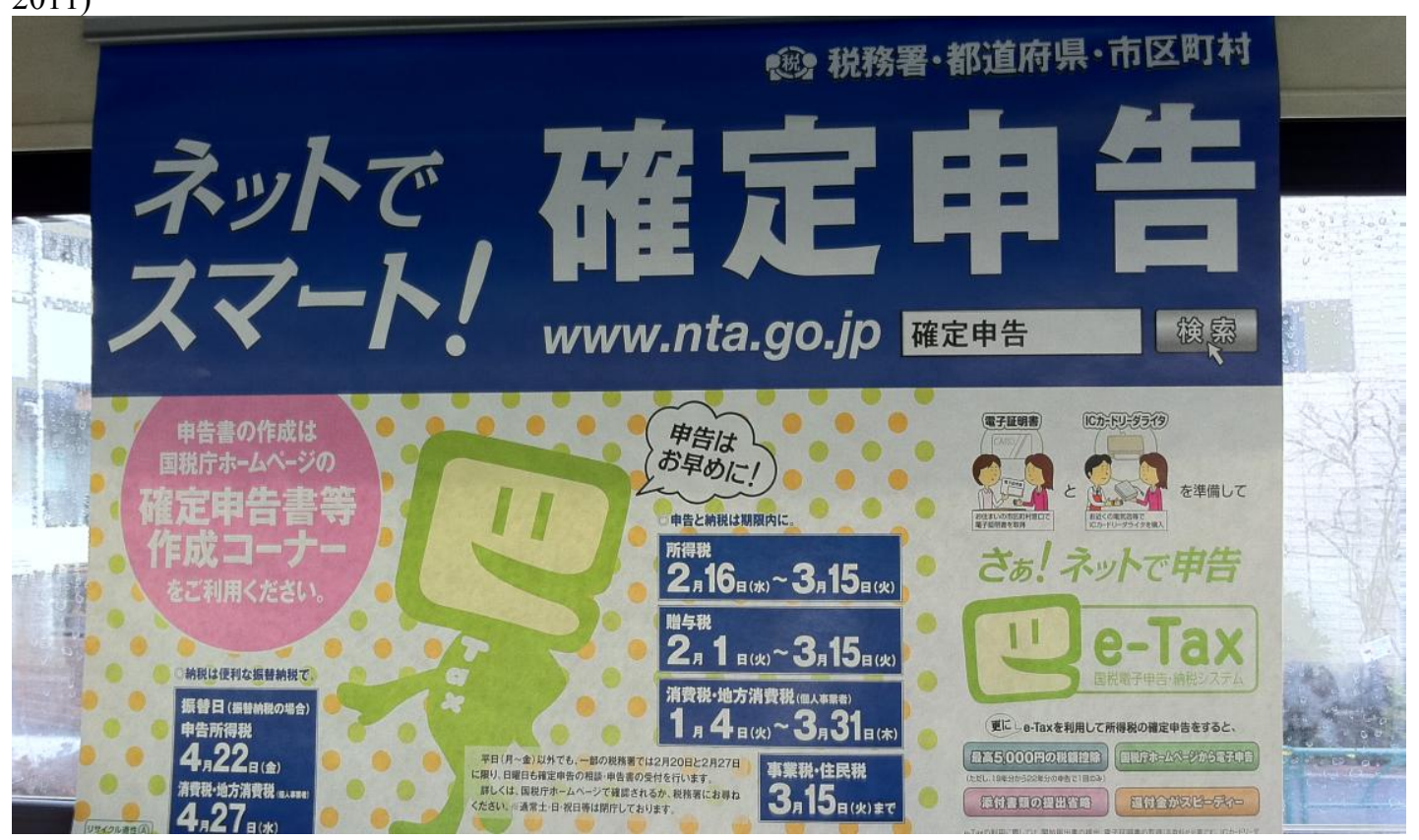


The implications of instances like the above can be either pessimistic or optimistic. The pessimistic view, perhaps also realistic, is that the mainstream public does not sufficiently take into account the ELW comprehension problems among people, especially among those over 60 years old, which causes them to be excluded from resources and information otherwise available. The optimistic view, on the other hand, might be that the ELW-filled environment provides more exposure to ELWs, hence urging people to learn them. The latter might have some grounds, according to the reports from the Ministry of Internal Affairs and Communications (2006, 2011), which indicated that internet use percentages for ages 65 older increased by $16 \%$ between 2005 and 2010 . The increase of computer use among the older generation is likely to improve their knowledge of ELWs related to computer, and by extension, their comprehension of internet texts.

If the knowledge of ELWs is a matter of personal preference or interest, the damage of not knowing them would be minimal. However, as the example of the flyer on the bus and the frequent use of high-frequency ELWs in white papers $(14,293 / \mathrm{M})$ illustrate, ELWs are frequently used to communicate practical information; thus, lack of knowledge of such ELWs could result in impairing one's civic life. One of the first steps to prevent such problems from spreading could be to periodically assess people's comprehension rates of frequently-occurring ELWs, and have the government use the results to select appropriate vocabulary for public materials. Such an approach would efficiently address the problem areas and keep track of the changes in the uses of ELWs.

Also, it is important to increase younger people's awareness of the comprehension rate gap---an average $20 \%$ difference---between them and the older generation. Such gap 
is likely to continue to exist as long as the younger generation plays an active role in the process of incorporation and creative modification of new ELWs. By understanding the current state of the comprehension gap and the consequences of non-comprehension, the younger generation could begin to monitor their use of ELWs.

On a sociological note, the increasing number of ELWs and the low comprehension by the older people might signify the elevated status of the younger generation, as knowledge of any kind often translates to social power. While this view is controversial, given the traditional Japanese values in which younger people are to remain subordinate to their elders, it is true that the elder's low comprehension of ELWs could keep them from accessing valuable information that the younger people have.

There are a series of events and social changes that might have contributed to this social change. The economic boom in the 60's and the 70's led to the increase of nuclear families, which led to the aging society, gradually changing the former providers of the family to the ones in need of care. In addition, the recent advancement of information technology has changed the manners in which people are expected to communicate with one another. In present Japan, it would be difficult for one to gain social status if he or she does not know how to perform basic computer tasks, such as to download digital contents on the web. Thus, the implications of ELW low comprehension rates are not only practical, but also social.

\section{Limitations to the Study and Suggestions for Future Research}

One of the limitations to this study was the age of the data. The corpus data was taken from texts produced between 2001 and 2005, which is nearly a decade ago, and some of the information may no longer be relevant to the present day. In particular, the 
comprehension rates are likely to have changed in the past 10 years, considering the rapid increase of Internet usage among the older generation (Ministry of Internal Affairs and Communications, 2011).

In addition, because the loan words surveyed in the NINJAL comprehension study only included 52 of the high-frequency ELWs, it was not possible to analyze the comprehension rates for all of the semantic categories. Although I was able to observe some general trends of comprehension by the semantic categories, additional data is needed in order to confirm these trends.

Therefore, one of the suggestions for future studies is to conduct a new comprehension study that specifically targets high-frequency ELWs, which would improve the validity of the results. In addition, surveys that would elicit the nature of comprehension, such as multiple questions and true-or-false questions, are likely to provide more accurate information about the respondent's true understanding of ELWs.

Another suggestion is to explore the relationship between topics and registers, and investigate how the two interplay with respect to language features. When language features vary across topics, and also across registers, which one is it that influences the language features more than the other? What happens to the language features in varying registers when topics are the same?

\section{Conclusion}

My personal gain from this research was the realization of the magnitude: the magnitude of the prevalence of ELWs, the magnitude of the comprehension gap between the $60+$ group and the overall age group, and the magnitude of the implications that the comprehension gap could have. With an average $20 \%$ comprehension difference for 
words that occur frequently, it is no wonder that people with low ELW comprehension might feel discouraged, upset, and even excluded from society. It is my hope that my study findings will somehow contribute to the efforts being made to alleviate problems caused by low comprehension of ELWs, especially in public settings where information should reach all ages. 


\section{References}

Aizawa, M. (2006). Attitude towards the actual state of loanwords. Loanwords in the public media:Basic researches for suggestions for paraphrasing loanwords (2.1). Retrieved from http://www.kokken.go.jp/gairaigo/Report126/report126.html

Akamatsu, N. (2006). Literacy acquisition in Japanese-English bilinguals. In R. Joshi \& P. Aaron (Eds.), Handbook of orthography and literacy. (pp. 481-496). Mahwarh, NJ: Lawrence Erlbaum Associates.

Baker, C. \& Jones, S.P. (1998). Encyclopedia of bilingualism and bilingual education. Philadelphia, PA: Multilingual Matters.

Biber, D., Conrad, S. \& Leech, G. (2002). The Longman student grammar of spoken and written English. Harlow, England: Pearson Education.

Biber, D., \& Conrad, S. (2009). Register, genre, and style. Cambridge, UK: Cambridge University Press.

Cabinet Secretariat, Cabinet Public Relations Office. (2010). Prime minister of Japan and his cabinet. Retrieved from http://www.kantei.go.jp/

Daulton, F. (1999). English loanwords in Japanese: The built-in lexicon. The Internet TESL Journal, 5. Retrieved from http://iteslj.org/Articles/Daulton0Loanwords.html

Daulton, F. (2008). Japan's built-in lexicon of English-based loanwords. Clevedon, England: Multilingual Matters.

Davis, M. (2011). Word frequency data from the Corpus of Contemporary American English (COCA) [Data file]. Retrieved from http://www.wordfrequency.info

Den, Y., Yamada, A., Ogura, H., Koiso, H., Ogiso, T. (2010). UniDic (Version 1.3.12) [software]. Retrieved from http://www.tokuteicorpus.jp/dist/

Hogan, J. (2003). The social significance of English usage in Japan. Japanese Studies, 23(1), 43-58.

Inaga, K., Takemori, T., \& Morino, S. (Eds.). (1997). Sogo kokugo binran. Tokyo: Daiichi Gakushuusha

Irwin, M. (2005). Rendaku-based lexical hierarchies in Japanese: The behavior of SinoJapanese mononoms in hybrid noun compounds. Journal of East Asian Linguistics, 14(2), 121-153. 
Kay, G. (1995). English loanwords in Japanese. World Englishes, 14(1), 66-76.

Kachru, Y. \& Nelson, C. (2006). World Englishes in Asian contexts. Hong Kong: Hong Kong University Press.

Kess, J. F., \& Miyamoto, T. (1999). The Japanese mental lexicon: Psycholinguistics studies of kana and kanji processing. Philadelphia, PA: John Benjamins Publishing Company.

Kindaichi, K., Saeki, U., Oishi, H., Nomura, \& M. (Eds.). (2002). Shinsen kokugo jiten. Tokyo: Shogakukan.

Kiryu, R. (2007). Genres of newspaper and loanwords. Loanwords in the public media :Basic researches for suggestions for paraphrasing loanwords (3.2). Retrieved from http://www.ninjal.ac.jp/gairaigo/Report126/houkoku3-2.pdf

Kowner, R. and Daliot-Bul, M. (2008). Japanese: The dialectic relationships between „Westerness' and „Japaneseness' as reflected in English loanwords. In J. Rosenhouse \& R. Kowner (Eds.), Globally speaking: motives for adopting English vocabulary in other languages (pp. 250-275). New York: Multilingual Matters.

Kubozono, H. (1995). Perceptual evidnce for the mora in Japanese. In B. Connell \& A. Arvantiti (Eds.), Phonology and phonetic evidence (pp. 141-156). New York: Cambridge University Press.

Kubozono, H. (2005). Where does loanword prosody come from? A case study of Japanese loanword accent. Lingua, 116(7), 1140-1170.

Loveday, L. (1996). Language contact in Japan: A socio-linguistic history. New York: Oxford University Press.

Loveday, L. (2008). Creating a mock-Western identity through English in Japanese ads: A study of occidentalist invocations. Journal of Creative Communications, 3(2), 123-153.

Maekawa, K. (2007). Proceedings from the Symposium on Large-Scale Knowledge Resources (LKR 2007): Design of a balanced corpus of contemporary written Japanese. Tokyo, Japan, 55-58. Retrieved from http://www2.ninjal.ac.jp/kikuo/KMHP1Eng.html

Maruyama, T. (2009). Bibliography, samples, and authors. In balanced corpus of contemporary written Japanese: Monitor data 2009 version [DVD]. Tokyo, Japan. 
Miller, R. (1967). The Japanese language. Chicago: University of Chicago Press.

Miller, R. (1986). Nihongo: In defence of Japanese. London: Athlone Press.

Ministry of Internal Affairs and Communications. (2006). Heisei 17nen tsuushin riyou doukou chousa no kekka. Retrieved from http://www.soumu.go.jp/

Ministry of Internal Affairs and Communications. (2011). Heisei 22nen tsuushin riyou doukou chousa no kekka. Retrieved from http://www.soumu.go.jp/

Murphy, M. (2010). Lecical Meaning. Cambridge: Cambridge University Press.

Myers-Scotton, C. (2006). Multiple voices: An introduction to bilingualism. Malden, MA: Blackwell Publishers.

National Institute for Japanese Language and Linguistics. (2004). Gairaigo ni kansuru ishiki chousa. Retrieved from http://www.ninjal.ac.jp/productsk/katsudo/seika/genzai/ishiki/

National Institute for Japanese Language and Linguistics. (2006). Gairaigo teichakudo chousa. Retrieved from http://www.ninjal.ac.jp/gairaigo/Yoron/index.html

National Institute for Japanese Language and Linguistics. (2007). Loanwords in the public media :Basic researches for suggestions for paraphrasing loanwords. Retrieved from http://www.ninjal.ac.jp/gairaigo/Report126/report126.html

National Institute for Japanese Language and Linguistics. (2009). Balanced corpus of contemporary written Japanese: Monitor data 2009 version [DVD]. Tokyo, Japan.

National Institute for Japanese Language and Linguistics. (2011). Kotonoha. Retrieved from http://www.ninjal.ac.jp/kotonoha/ex_2.html\#04

Sanseido. (2010). Sanseido Word-Wise Web. Retreived from http://dictionary.sanseido-publ.co.jp/dicts/ja/conkatakana4/index.html

Shibatani, M. (1990). The languages of Japan. New York: Cambridge University Press.

Stanlaw, J. (2004). Japanese English: Language and culture contact. Hong Kong: Hong Kong University Press.

Tanaka, M. (2007). Features of loanwords in the public media: White papers, public relations bulletins and newspapers. Loanwords in the public media :Basic researches for suggestions for paraphrasing loanwords (3.1). Retrieved from http://www.ninjal.ac.jp/gairaigo/Report126/houkoku3-1.pdf 
Tsujimura, N. (1996). An introduction to Japanese linguistics. Victoria, Australia: Blackwell Publishers Ltd.

Yamane, N. (2001). Clusters as complex segments: Evidence from the contrastive phonology of English and Japanese. In J. M. van de Weijer \& T. Nishihara (Eds.), Issues in Japanese phonology and morphology (pp. 357-387). Berlin: Walter de Gruyter.

Yan, Y. (1994). Wan ren xian dai Han Ying ci dian [Mass modern Chinese-English dictionary]. Guangzhou: Shi jie tu shu. 


\section{Appendix A: High-frequency ELWs}

\begin{tabular}{|c|c|c|c|c|c|c|c|}
\hline $\begin{array}{l}\text { EL } \\
\text { W } \\
\text { ID }\end{array}$ & 語番素 (338 Types) & $\begin{array}{l}\text { English (original } \\
\text { form) }\end{array}$ & Semantic category & Loan Type & WP & $\mathbf{B K}$ & IT \\
\hline 1 & アウト & out & $\begin{array}{l}\text { General } \\
\text { (Function word) }\end{array}$ & Core & $x$ & $x$ & 0 \\
\hline 2 & アクセス & access & Multiple & Core/Cultural & 0 & $\mathrm{x}$ & 0 \\
\hline 3 & アップ & up & General (Function word) & Core & 0 & 0 & 0 \\
\hline 4 & アドバイス & advice & General & Core & $\mathrm{x}$ & $x$ & 0 \\
\hline 5 & アドレス & address & Multiple & Core/Cultural & $x$ & $x$ & 0 \\
\hline 6 & アナログ & analog & Science \& Technology & Cultural & 0 & $x$ & $x$ \\
\hline 7 & アニメ & anime & Media \& Entertainment & Cultural & $x$ & $x$ & 0 \\
\hline 8 & アパート & apartment & Building \& Furniture & Core & $\mathrm{x}$ & $x$ & 0 \\
\hline 9 & アルバム & album & Multiple & Cultural & $x$ & $\mathrm{x}$ & 0 \\
\hline 10 & アレルギー & allergy & Medical, Health \& Beauty & Core & $\mathrm{x}$ & $\mathrm{x}$ & 0 \\
\hline 11 & アンサー & answer & General & Core & $x$ & $\mathrm{x}$ & 0 \\
\hline 12 & アンド & and & General (Function word) & Core & 0 & 0 & 0 \\
\hline 13 & イオン-Ion & ion & Material \& substance & Cultural & $\mathrm{x}$ & 0 & $x$ \\
\hline 14 & イスラム & Islam & Social \& Public Life & Cultural & $x$ & 0 & $\mathrm{x}$ \\
\hline 15 & イニシアチブ & initiative & Social \& Public Life & Core & 0 & $x$ & $\mathrm{x}$ \\
\hline 16 & イベント & event & Social \& Public Life & Core & 0 & $x$ & $\mathrm{x}$ \\
\hline 17 & イメージ & image & Multiple & Core/Cultural & 0 & 0 & 0 \\
\hline 18 & イン-in & in & General (Function word) & Core & 0 & 0 & 0 \\
\hline 19 & インストール & install & Science \& Technology & Cultural & $x$ & $x$ & 0 \\
\hline 20 & インターネット & internet & Science \& Technology & Cultural & 0 & 0 & 0 \\
\hline 21 & インフラ & infrastructure & Social \& Public Life & Core & 0 & $\mathrm{x}$ & $\mathrm{x}$ \\
\hline 22 & ウイルス & virus & Medical, Health \& Beauty & Cultural & $x$ & $\mathrm{x}$ & 0 \\
\hline 23 & ウィン-win- & win & Science \& Technology & Cultural & $x$ & $\mathrm{x}$ & 0 \\
\hline 24 & ウインドー & window & Multiple & Core/Cultural & $\mathrm{x}$ & $x$ & 0 \\
\hline 25 & ウェブ & web & Science \& Technology & Cultural & $x$ & $\mathrm{x}$ & 0 \\
\hline 26 & ウラン & uranium & Material \& substance & Cultural & 0 & $x$ & $\mathrm{x}$ \\
\hline 27 & エアー & air & Multiple & Core/Cultural & $x$ & $x$ & 0 \\
\hline 28 & エアコン & air conditioner & Science \& Technology & Cultural & $x$ & $x$ & 0 \\
\hline 29 & エイト & eight & Numeral \& Math & Core & 0 & $\mathrm{x}$ & $\mathrm{x}$ \\
\hline 30 & エクセル & excel & Science \& Technology & Cultural & $x$ & $\mathrm{x}$ & 0 \\
\hline 31 & エネルギー & energy & Multiple & Core & 0 & 0 & $x$ \\
\hline 32 & エラー & error & General & Core & $x$ & $\mathrm{x}$ & 0 \\
\hline 33 & エリア & area & Social \& Public Life & Core & 0 & $x$ & $\mathrm{x}$ \\
\hline 34 & エンジン & engine & Vehicle & Cultural & $\mathrm{x}$ & $x$ & 0 \\
\hline 35 & オア & or & General (Function word) & Core & $x$ & $x$ & 0 \\
\hline 36 & オイル & oil & Multiple & Core & $\mathrm{x}$ & $x$ & 0 \\
\hline 37 & オークション & auction & Economy $\&$ business & Core & $\mathrm{x}$ & $\mathrm{x}$ & 0 \\
\hline 38 & オーケー & $\mathrm{OK}$ & General & Core & $\mathrm{x}$ & $x$ & 0 \\
\hline 39 & オフ & off & General (Function word) & Core & $\mathrm{x}$ & $x$ & 0 \\
\hline 40 & オブ & of & General (Function word) & Core & 0 & 0 & 0 \\
\hline 41 & オフィス & office & Economy $\&$ business & Core & 0 & $\mathrm{x}$ & $\mathrm{x}$ \\
\hline 42 & オプション & option & General & Core & $\mathrm{x}$ & $\mathrm{x}$ & 0 \\
\hline 43 & オン & on & General (Function word) & Core & 0 & 0 & 0 \\
\hline 44 & カー & car & Vehicle & Cultural & $\mathrm{x}$ & $x$ & 0 \\
\hline 45 & カード & card & Multiple & Core/Cultural & $x$ & 0 & 0 \\
\hline 46 & ガイド & guide & Social \& Public Life & Core & 0 & $x$ & $\mathrm{x}$ \\
\hline 47 & ガイドライン & guideline & Social \& Public Life & Core & 0 & $\mathrm{x}$ & $\mathrm{x}$ \\
\hline 48 & ガス & gas & Material \& substance & Core & 0 & 0 & 0 \\
\hline
\end{tabular}




\begin{tabular}{|c|c|c|c|c|c|c|c|}
\hline 49 & ガソリン & gasoline & Material \& substance & Cultural & $\mathrm{x}$ & $x$ & 0 \\
\hline 50 & カット & cut & General & Core & $x$ & $x$ & 0 \\
\hline 51 & カップ & cup & Multiple & Core/Cultural & $\mathrm{x}$ & $\mathrm{x}$ & 0 \\
\hline 52 & カテゴリー & category & General & Core & $x$ & $\mathrm{x}$ & 0 \\
\hline 53 & カバー & cover & Multiple & Core & $x$ & $\mathrm{x}$ & 0 \\
\hline 54 & カメラ & camera & Science \& Technology & Cultural & $x$ & 0 & 0 \\
\hline 55 & カラー-color & color & General & Core & $x$ & $x$ & 0 \\
\hline 56 & ガラス & glass & Material \& substance & Core & $x$ & 0 & 0 \\
\hline 57 & カレー & curry & Dining \& food & Cultural & $x$ & $x$ & 0 \\
\hline 58 & カロリー & calorie & Measurement \& unit & Cultural & $x$ & $x$ & 0 \\
\hline 59 & キー & key & Multiple & Core/Cultural & $x$ & 0 & 0 \\
\hline 60 & キス & kiss & Personal \& Family Life & Core & $\mathrm{x}$ & $\mathrm{x}$ & 0 \\
\hline 61 & ギター & guitar & Media \& Entertainment & Cultural & $x$ & $x$ & 0 \\
\hline 62 & キャラ & character & Multiple & Core & $x$ & $\mathrm{x}$ & 0 \\
\hline 63 & キャンセル & cancel & General & Core & $x$ & $x$ & 0 \\
\hline 64 & キロ & kilo & Measurement \& unit & Cultural & $x$ & 0 & 0 \\
\hline 65 & キログラム & kilogram & Measurement \& unit & Cultural & 0 & $\mathrm{x}$ & 0 \\
\hline 66 & キロメートル & kilometer & Measurement \& unit & Cultural & 0 & $x$ & 0 \\
\hline 67 & クエスチョン & question & General & Core & $\mathrm{x}$ & $\mathrm{x}$ & 0 \\
\hline 68 & クラス & class & Multiple & Core & $x$ & 0 & 0 \\
\hline 69 & クラブ & club & Multiple & Core/Cultural & 0 & 0 & 0 \\
\hline 70 & グラム & gram & Measurement \& unit & Cultural & $\mathrm{x}$ & 0 & 0 \\
\hline 71 & クリア & clear & Multiple & Core & $x$ & $x$ & 0 \\
\hline 72 & クリーム & cream & Multiple & Cultural & $\mathrm{x}$ & $x$ & 0 \\
\hline 73 & グリーン & green & Multiple & Core & 0 & $\mathrm{x}$ & $x$ \\
\hline 74 & クリスマス & Christmas & Social \& Public Life & Cultural & $x$ & $x$ & 0 \\
\hline 75 & クリック & click & Science \& Technology & Cultural & $x$ & 0 & 0 \\
\hline 76 & グループ & group & General & Core & 0 & 0 & 0 \\
\hline 77 & クレーム & claim & Economy \& business & Core & $\mathrm{x}$ & $\mathrm{x}$ & 0 \\
\hline 78 & クレジット & credit & Economy $\&$ business & Cultural & $x$ & $\mathrm{x}$ & 0 \\
\hline 79 & グローバル & global & Social \& Public Life & Core & 0 & $x$ & $\mathrm{x}$ \\
\hline 80 & ケア & care & Medical, Health \& Beauty & Core & 0 & 0 & $x$ \\
\hline 81 & ケーキ & cake & Dining \& food & Core-Western & $x$ & $x$ & 0 \\
\hline 82 & ケース & case & Multiple & Core & 0 & 0 & 0 \\
\hline 83 & ケーブル & cable & Science \& Technology & Cultural & 0 & $x$ & 0 \\
\hline 84 & ゲーム & game & Media \& Entertainment & Core & $\mathrm{x}$ & 0 & 0 \\
\hline 85 & コース & course & Multiple & Core & $x$ & 0 & 0 \\
\hline 86 & コード-code & code & Multiple & Core/Cultural & $\mathrm{x}$ & $\mathrm{x}$ & 0 \\
\hline 87 & コーヒー & coffee & Dining \& food & Cultural & $\mathrm{x}$ & 0 & 0 \\
\hline 88 & コスト & cost & Economy \& business & Core & 0 & 0 & $\mathrm{x}$ \\
\hline 89 & コピー & copy & General & Core & $x$ & $x$ & 0 \\
\hline 90 & コミュニケーション & communication & Social \& Public Life & Core & 0 & 0 & $x$ \\
\hline 91 & コミュニティー & community & Social \& Public Life & Core & 0 & $x$ & $x$ \\
\hline 92 & ゴム & gum & Material \& substance & Cultural & $x$ & $x$ & 0 \\
\hline 93 & コメント & comment & General & Core & $\mathrm{x}$ & $\mathrm{x}$ & 0 \\
\hline 94 & コンクリート & concrete & Material \& substance & Cultural & 0 & $x$ & $x$ \\
\hline 95 & コンテンツ & contents & Science \& Technology & Core/Cultural & 0 & $x$ & $x$ \\
\hline 96 & コントロール & control & General & Core & $x$ & 0 & 0 \\
\hline 97 & コンビニ & convenience store & Economy \& business & Cultural & $\mathrm{x}$ & $x$ & 0 \\
\hline 98 & コンピューター & computer & Science \& Technology & Cultural & 0 & 0 & 0 \\
\hline 99 & ザ & the & General (Function word) & Core & $x$ & 0 & 0 \\
\hline 100 & サーバー & server & Science \& Technology & Cultural & $\mathrm{x}$ & $\mathrm{x}$ & 0 \\
\hline 101 & サービス & service & Multiple & Core & 0 & 0 & 0 \\
\hline
\end{tabular}




\begin{tabular}{|c|c|c|c|c|c|c|c|}
\hline 102 & サイエンス & science & Science \& Technology & Core & 0 & $x$ & $x$ \\
\hline 103 & サイクル & cycle & Multiple & Core/Cultural & 0 & $\mathrm{x}$ & $x$ \\
\hline 104 & サイズ & size & General & Core & $x$ & $x$ & 0 \\
\hline 105 & サイト & site & Science \& Technology & Cultural & 0 & $\mathrm{x}$ & 0 \\
\hline 106 & サッカー & soccer & Sports & Cultural & $x$ & $x$ & 0 \\
\hline 107 & サミット & summit & Social \& Public Life & Cultural & 0 & $x$ & $x$ \\
\hline 108 & サラダ & salad & Dining \& food & Core-Western & $x$ & $x$ & 0 \\
\hline 109 & シート-sheet & sheet & Multiple & Core/Cultural & 0 & $x$ & 0 \\
\hline 110 & シール & seal & General & Core & $x$ & $x$ & 0 \\
\hline 111 & シーン & scene & General & Core & $x$ & $\mathrm{x}$ & 0 \\
\hline 112 & シェア & share & Economy \& business & Core/Cultural & 0 & $x$ & $x$ \\
\hline 113 & システム & system & General & Core & 0 & 0 & 0 \\
\hline 114 & シャツ & shirt & Personal \& Family Life & Core-Western & $\mathrm{x}$ & $\mathrm{x}$ & 0 \\
\hline 115 & シャンプー & shampoo & Medical, Health \& Beauty & Core-Western & $\mathrm{x}$ & $\mathrm{x}$ & 0 \\
\hline 116 & ショー & show & Media \& Entertainment & Core & $x$ & $x$ & 0 \\
\hline 117 & ショック & shock & General & Core & $x$ & $x$ & o \\
\hline 118 & ショップ & shop & Economy \& business & Core & $x$ & $x$ & 0 \\
\hline 119 & シリーズ & series & General & Core & $x$ & $x$ & 0 \\
\hline 120 & シンポジウム & symposium & Social \& Public Life & Core & 0 & $x$ & $x$ \\
\hline 121 & スーツ & suit & Personal \& Family Life & Cultural & $\mathrm{x}$ & $\mathrm{x}$ & 0 \\
\hline 122 & スーパー-super & super & Multiple & Core/Cultural & $x$ & $x$ & 0 \\
\hline 123 & スープ & soup & Dining \& food & Core-Western & $x$ & $x$ & 0 \\
\hline 124 & スタート & start & General & Core & $x$ & 0 & 0 \\
\hline 125 & スタイル & style & Multiple & Core & $\mathrm{x}$ & 0 & 0 \\
\hline 126 & スタッフ-staff & staff & General & Core & $x$ & 0 & $x$ \\
\hline 127 & ストック-stock & stock & Economy \& business & Cultural & 0 & $x$ & $\mathrm{x}$ \\
\hline 128 & ストレス & stress & Medical, Health \& Beauty & Core & $\mathrm{x}$ & 0 & 0 \\
\hline 129 & スピード & speed & General & Core & $x$ & 0 & 0 \\
\hline 130 & スポーツ & sports & Sports & Core & 0 & 0 & 0 \\
\hline 131 & セキュリティー & security & General & Core & $x$ & $\mathrm{x}$ & 0 \\
\hline 132 & セックス & sex & Personal \& Family Life & Core & $x$ & $\mathrm{x}$ & 0 \\
\hline 133 & セット & set & Multiple & Core & $\mathrm{x}$ & $x$ & 0 \\
\hline 134 & セミナー & seminar & Social \& Public Life & Core & 0 & $\mathrm{x}$ & $\mathrm{x}$ \\
\hline 135 & セル-cell & cell & Science \& Technology & Cultural & $\mathrm{x}$ & $\mathrm{x}$ & 0 \\
\hline 136 & ゼロ & zero & Numeral \& Math & Core & 0 & $\mathrm{x}$ & $\mathrm{x}$ \\
\hline 137 & センター & center & Multiple & Core & 0 & 0 & 0 \\
\hline 138 & センチ & centimeter & Measurement \& unit & Cultural & $x$ & 0 & 0 \\
\hline 139 & センチメートル & centimeter & Measurement \& unit & Cultural & $x$ & 0 & 0 \\
\hline 140 & ソース-sauce & sauce & Dining \& food & Core-Western & $\mathrm{x}$ & $x$ & 0 \\
\hline 141 & ソフト & soft & Multiple & Core/Cultural & 0 & 0 & 0 \\
\hline 142 & ダイエット & diet & Medical, Health \& Beauty & Core & $x$ & $x$ & 0 \\
\hline 143 & タイトル & title & Multiple & Core & $\mathrm{x}$ & $\mathrm{x}$ & 0 \\
\hline 144 & タイプ-type & type & General & Core & $x$ & 0 & 0 \\
\hline 145 & タイミング & timing & General & Core & $x$ & $\mathrm{x}$ & 0 \\
\hline 146 & タイム-time & time & General & Core & 0 & 0 & 0 \\
\hline 147 & タイヤ & tire & Vehicle & Cultural & $x$ & $\mathrm{x}$ & 0 \\
\hline 148 & ダウン & down & General (Function word) & Core & $\mathrm{x}$ & $\mathrm{x}$ & 0 \\
\hline 149 & ダウンロード & download & Science \& Technology & Cultural & $x$ & $x$ & 0 \\
\hline 150 & タオル & towel & General & Core-Western & $\mathrm{x}$ & $\mathrm{x}$ & 0 \\
\hline 151 & タバコ & Tabaco & Material \& substance & Cultural & $\mathrm{x}$ & 0 & 0 \\
\hline 152 & タレント & talent & Media \& Entertainment & Core & $x$ & $x$ & 0 \\
\hline 153 & チーズ & cheese & Dining \& food & Cultural & $\mathrm{x}$ & $\mathrm{x}$ & 0 \\
\hline 154 & チーム & team & General & Core & 0 & 0 & 0 \\
\hline
\end{tabular}




\begin{tabular}{|c|c|c|c|c|c|c|c|}
\hline 155 & チェック & check & General & Core & $x$ & 0 & 0 \\
\hline 156 & チケット & ticket & General & Core & $x$ & $x$ & 0 \\
\hline 157 & チャリティー & charity & Social \& Public Life & Core & 0 & $x$ & $x$ \\
\hline 158 & チャンス & chance & General & Core & $x$ & 0 & 0 \\
\hline 159 & チャンネル & channel & Media \& Entertainment & Cultural & 0 & $x$ & 0 \\
\hline 160 & ツアー & tour & Media \& Entertainment & Core & $x$ & $x$ & 0 \\
\hline 161 & ツー-to & to & General (Function word) & Core & $x$ & $x$ & 0 \\
\hline 162 & ツー-two & two & Numeral \& Math & Core & $x$ & $\mathrm{x}$ & 0 \\
\hline 163 & ツール & tool & Multiple & Core/Cultural & $x$ & $x$ & 0 \\
\hline 164 & ディーラー & dealer & Economy \& business & Core & $x$ & $x$ & 0 \\
\hline 165 & ディスク & disk & Science \& Technology & Cultural & $x$ & $x$ & 0 \\
\hline 166 & ディテール & detail & General & Core & $x$ & $x$ & 0 \\
\hline 167 & デー & day & General & Core & $\mathrm{x}$ & $\mathrm{x}$ & 0 \\
\hline 168 & データ & data & Multiple & Core/Cultural & 0 & 0 & 0 \\
\hline 169 & データーベース & database & Science \& Technology & Cultural & 0 & $x$ & $x$ \\
\hline 170 & デート & date & Personal \& Family Life & Core & $x$ & $x$ & 0 \\
\hline 171 & テープ & tape & Multiple & Core/Cultural & $x$ & $x$ & 0 \\
\hline 172 & テーブル & table & Building \& Furniture & Core-Western & $x$ & 0 & $x$ \\
\hline 173 & テーマ & theme & General & Core & 0 & 0 & $x$ \\
\hline 174 & デザイン & design & General & Core & 0 & 0 & 0 \\
\hline 175 & デジカメ & digital camera & Science \& Technology & Cultural & $x$ & $x$ & 0 \\
\hline 176 & デジタル & digital & Science \& Technology & Cultural & 0 & $x$ & 0 \\
\hline 177 & デスクトップ & desktop & Science \& Technology & Cultural & $x$ & $x$ & 0 \\
\hline 178 & テスト & test & General & Core & $x$ & 0 & 0 \\
\hline 179 & デフレ & deflation & Economy \& business & Core & 0 & $x$ & $x$ \\
\hline 180 & テレビ & television & Science \& Technology & Cultural & 0 & 0 & 0 \\
\hline 181 & テレビジョン & television & Science \& Technology & Cultural & 0 & $x$ & $x$ \\
\hline 182 & テロ & terrorism & Social \& Public Life & Core & 0 & $x$ & $x$ \\
\hline 183 & ドア & door & Building \& Furniture & Core-Western & $x$ & 0 & 0 \\
\hline 184 & トイレ & toilet & Building \& Furniture & Core & $x$ & 0 & 0 \\
\hline 185 & トップ & top & Multiple & Core & $x$ & 0 & 0 \\
\hline 186 & ドライバー & driver & Vehicle & Cultural & $x$ & $x$ & 0 \\
\hline 187 & ドライブ & drive & Vehicle & Cultural & $x$ & $x$ & 0 \\
\hline 188 & トラブル & trouble & General & Core & $x$ & $x$ & 0 \\
\hline 189 & ドラマ & drama & Media \& Entertainment & Core & $x$ & $x$ & 0 \\
\hline 190 & ドル & dollar & Economy \& business & Cultural & 0 & 0 & 0 \\
\hline 191 & トン & ton & Measurement \& unit & Cultural & 0 & $x$ & $\mathrm{x}$ \\
\hline 192 & ナンバー & number & Numeral \& Math & Core & $x$ & $x$ & 0 \\
\hline 193 & ニーズ & needs & Social \& Public Life & Core & 0 & 0 & $x$ \\
\hline 194 & ニュー & new & General & Core & $x$ & $x$ & 0 \\
\hline 195 & ニュース & news & Media \& Entertainment & Core & $x$ & 0 & 0 \\
\hline 196 & ネット & net & Science \& Technology & Cultural & 0 & $x$ & 0 \\
\hline 197 & ネットワーク & network & Multiple & Core/Cultural & 0 & 0 & $x$ \\
\hline 198 & ノウハウ & knowhow & General & Core & 0 & $\mathrm{x}$ & $x$ \\
\hline 199 & ノー & no & General (Function word) & Core & $x$ & $x$ & 0 \\
\hline 200 & ノート & note & General & Core & $x$ & $x$ & 0 \\
\hline 201 & バー & bar & Dining \& food & Core-Western & $x$ & $x$ & 0 \\
\hline 202 & バージョン & version & General & Core & $x$ & $x$ & 0 \\
\hline 203 & パーセント & percent & Measurement \& unit & Cultural & 0 & 0 & 0 \\
\hline 204 & ハード & hard & Multiple & Core/Cultural & 0 & $x$ & $x$ \\
\hline 205 & パート-part & part & Multiple & Core & 0 & $x$ & 0 \\
\hline 206 & パートナーシップ & partnership & Social \& Public Life & Core & 0 & $x$ & $x$ \\
\hline 207 & バイ-by & by & General (Function word) & Core & $x$ & $x$ & 0 \\
\hline
\end{tabular}




\begin{tabular}{|c|c|c|c|c|c|c|c|}
\hline 208 & ハイ-high & high & General & Core & $x$ & $x$ & 0 \\
\hline 209 & バイオマス & biomass & Science \& Technology & Cultural & 0 & $x$ & $\mathrm{x}$ \\
\hline 210 & バイク & bike & Vehicle & Cultural & $\mathrm{x}$ & $\mathrm{x}$ & 0 \\
\hline 211 & ハイテク & high-tech & Science \& Technology & Cultural & 0 & $\mathrm{x}$ & $x$ \\
\hline 212 & ハウス & house & Building \& Furniture & Core & $\mathrm{x}$ & 0 & $\mathrm{x}$ \\
\hline 213 & バス-bus & bus & Vehicle & Cultural & 0 & 0 & 0 \\
\hline 214 & パスワード & password & Science \& Technology & Core & $x$ & $x$ & 0 \\
\hline 215 & パソコン & personal computer & Science \& Technology & Cultural & 0 & 0 & 0 \\
\hline 216 & パターン & pattern & General & Core & $x$ & 0 & $\mathrm{x}$ \\
\hline 217 & バック & back & General (Function word) & Core & $x$ & $x$ & 0 \\
\hline 218 & パック-pack & pack & Multiple & Core & $x$ & $x$ & 0 \\
\hline 219 & バッテリー & battery & Science \& Technology & Cultural & $x$ & $\mathrm{x}$ & 0 \\
\hline 220 & パトロール & patrol & Social \& Public Life & Core & 0 & $x$ & $\mathrm{x}$ \\
\hline 221 & バブル & bubble & Economy \& business & Core & 0 & $\mathrm{x}$ & $\mathrm{x}$ \\
\hline 222 & バランス & balance & General & Core & 0 & 0 & 0 \\
\hline 223 & バリア & barrier & Multiple & Core & 0 & $x$ & $\mathrm{x}$ \\
\hline 224 & パワー & power & Multiple & Core & $x$ & $x$ & 0 \\
\hline 225 & バンク & bank & Economy \& business & Core & $x$ & $x$ & 0 \\
\hline 226 & パンツ & pants & Personal \& Family Life & Core-Western & $\mathrm{x}$ & $x$ & 0 \\
\hline 227 & バンド-band & band & Media \& Entertainment & Core-Western & $x$ & $x$ & 0 \\
\hline 228 & パンフレット & pamphlet & Social \& Public Life & Core & 0 & $\mathrm{x}$ & $\mathrm{x}$ \\
\hline 229 & ピアノ & piano & Media \& Entertainment & Cultural & $x$ & $\mathrm{x}$ & 0 \\
\hline 230 & ピーク & peak & General & Core & 0 & $\mathrm{x}$ & $\mathrm{x}$ \\
\hline 231 & ビール & beer & Dining \& food & Cultural & $x$ & 0 & 0 \\
\hline 232 & ビジネス & business & Economy \& business & Core & 0 & 0 & $\mathrm{x}$ \\
\hline 233 & ビタミン & vitamin & Material \& substance & Cultural & $x$ & $x$ & 0 \\
\hline 234 & ビデオ & video & Science \& Technology & Cultural & 0 & $x$ & 0 \\
\hline 235 & ビル-building & building & Building \& Furniture & Core-Western & 0 & 0 & $\mathrm{x}$ \\
\hline 236 & ファースト-first & first & General (Function word) & Core & $\mathrm{x}$ & $\mathrm{x}$ & 0 \\
\hline 237 & ファイル & file & Multiple & Cultural & $\mathrm{x}$ & 0 & 0 \\
\hline 238 & $\begin{array}{l}\text { ファン-fan（熱狂 } \\
\text { 者） }\end{array}$ & fan & Media \& Entertainment & Core & $x$ & $x$ & 0 \\
\hline 239 & フォーラム & forum & Social \& Public Life & Core & 0 & $x$ & $\mathrm{x}$ \\
\hline 240 & フォルダー & folder & Multiple & Cultural & $x$ & $\mathrm{x}$ & 0 \\
\hline 241 & プラス & plus & Numeral \& Math & Core & $x$ & $x$ & 0 \\
\hline 242 & プラスチック & plastic & Material \& substance & Cultural & 0 & $x$ & $\mathrm{x}$ \\
\hline 243 & プラン & plan & General & Core & 0 & $x$ & $\mathrm{x}$ \\
\hline 244 & ブランド & brand & Economy \& business & Core & $x$ & 0 & 0 \\
\hline 245 & フリー-free & free & Multiple & Core & 0 & $\mathrm{x}$ & 0 \\
\hline 246 & プリンター & printer & Science \& Technology & Cultural & $\mathrm{x}$ & $\mathrm{x}$ & 0 \\
\hline 247 & フル & full & General & Core & 0 & $x$ & 0 \\
\hline 248 & ブルー & blue & Multiple & Core & $\mathrm{x}$ & $\mathrm{x}$ & 0 \\
\hline 249 & プレー & play & Multiple & Core/Cultural & $x$ & $x$ & 0 \\
\hline 250 & プレーヤー & player & Multiple & Core/Cultural & $x$ & $x$ & 0 \\
\hline 251 & プレゼント & present & Social \& Public Life & Core & $x$ & $x$ & 0 \\
\hline 252 & プロ-pro & pro & General & Core & $x$ & 0 & 0 \\
\hline 253 & フロー & flow & Economy \& business & Core & 0 & $x$ & $\mathrm{x}$ \\
\hline 254 & プログラム & program & Multiple & Core/Cultural & 0 & 0 & 0 \\
\hline 255 & プロジェクト & project & General & Core & 0 & 0 & $\mathrm{x}$ \\
\hline 256 & プロセス & process & General & Core & 0 & 0 & $x$ \\
\hline 257 & ブロック-block & block & Multiple & Core/Cultural & 0 & $x$ & $\mathrm{x}$ \\
\hline 258 & プロバイダー & provider & Science \& Technology & Cultural & $x$ & $\mathrm{x}$ & 0 \\
\hline 259 & ページ & page & Multiple & Core/Cultural & 0 & 0 & 0 \\
\hline 260 & ベース-base & base & Multiple & Core/Cultural & 0 & 0 & $x$ \\
\hline
\end{tabular}




\begin{tabular}{|c|c|c|c|c|c|c|c|}
\hline 261 & ヘクタール & hectare & Measurement \& unit & Cultural & 0 & $\mathrm{x}$ & $\mathrm{x}$ \\
\hline 262 & ベスト-best & best & General & Core & $x$ & $\mathrm{x}$ & 0 \\
\hline 263 & ベッド & bed & Building \& Furniture & Core-Western & $\mathrm{x}$ & 0 & $\mathrm{x}$ \\
\hline 264 & ペット-pet & pet & Personal \& Family Life & Core & $\mathrm{x}$ & $x$ & 0 \\
\hline 265 & ベビー & baby & Personal \& Family Life & Core & $x$ & $x$ & 0 \\
\hline 266 & ヘリコプター & helicopter & Vehicle & Cultural & 0 & $\mathrm{x}$ & $\mathrm{x}$ \\
\hline 267 & ポイント & point & Measurement \& unit & Core & 0 & 0 & 0 \\
\hline 268 & ボーナス & bonus & Economy \& business & Core & $x$ & $\mathrm{x}$ & 0 \\
\hline 269 & ホーム-home & home & Multiple & Core/Cultural & 0 & 0 & 0 \\
\hline 270 & ボール-ball & ball & Sports & Core & $x$ & 0 & 0 \\
\hline 271 & ボタン & button & Multiple & Cultural & $\mathrm{x}$ & 0 & 0 \\
\hline 272 & ボックス & box & Multiple & Core & $\mathrm{x}$ & $x$ & 0 \\
\hline 273 & ホテル & hotel & Economy \& business & Core-Western & $\mathrm{x}$ & 0 & 0 \\
\hline 274 & ボランティア & volunteer & Social \& Public Life & Core & 0 & $\mathrm{x}$ & $\mathrm{x}$ \\
\hline 275 & ホルモン & hormone & Medical, Health \& Beauty & Cultural & $\mathrm{x}$ & 0 & $\mathrm{x}$ \\
\hline 276 & マーク & mark & General & Core & $x$ & $x$ & 0 \\
\hline 277 & マイ & my & General (Function word) & Core & $x$ & $\mathrm{x}$ & 0 \\
\hline 278 & マイナス & minus & Numeral \& Math & Core & $\mathrm{x}$ & 0 & 0 \\
\hline 279 & マウス & mouse & Science \& Technology & Cultural & $\mathrm{x}$ & $\mathrm{x}$ & 0 \\
\hline 280 & マス & mass & Media \& Entertainment & Core & 0 & $x$ & $\mathrm{x}$ \\
\hline 281 & マップ & map & Social \& Public Life & Core & 0 & $\mathrm{x}$ & $\mathrm{x}$ \\
\hline 282 & マナー & manner & Social \& Public Life & Core & $x$ & $x$ & 0 \\
\hline 283 & マニュアル & manual & Multiple & Core/Cultural & 0 & $\mathrm{x}$ & $\mathrm{x}$ \\
\hline 284 & マネージメント & management & General & Core & 0 & 0 & $\mathrm{x}$ \\
\hline 285 & ママ & mama & Personal \& Family Life & Core & $x$ & 0 & 0 \\
\hline 286 & マン & $\operatorname{man}$ & General & Core & $x$ & 0 & 0 \\
\hline 287 & マンション & mansion & Building \& Furniture & Core & 0 & 0 & 0 \\
\hline 288 & ミー-me & me & General (Function word) & Core & $x$ & $\mathrm{x}$ & 0 \\
\hline 289 & ミサイル & missile & Science \& Technology & Cultural & 0 & $\mathrm{x}$ & $\mathrm{x}$ \\
\hline 290 & ミス-mistake & mistake & General & Core & $\mathrm{x}$ & $\mathrm{x}$ & 0 \\
\hline 291 & ミニ & $\operatorname{mini}$ & General & Core & $\mathrm{x}$ & $\mathrm{x}$ & 0 \\
\hline 292 & ミルク & milk & Dining \& food & Core & $\mathrm{x}$ & $\mathrm{x}$ & 0 \\
\hline 293 & メーカー & maker & Economy \& business & Core & 0 & 0 & 0 \\
\hline 294 & メーク & make & Medical, Health \& Beauty & Core & $x$ & $x$ & 0 \\
\hline 295 & メートル & meter & Measurement \& unit & Cultural & 0 & 0 & 0 \\
\hline 296 & メール-mail & mail & Science \& Technology & Cultural & $x$ & 0 & 0 \\
\hline 297 & メーン & main & General & Core & $x$ & $x$ & 0 \\
\hline 298 & メガバイト & mega bite & Measurement \& unit & Cultural & $x$ & $x$ & 0 \\
\hline 299 & メッセージ & message & Social \& Public Life & Core & $\mathrm{x}$ & 0 & 0 \\
\hline 300 & メディア & media & Media \& Entertainment & Core & 0 & 0 & 0 \\
\hline 301 & メニュー & menu & Dining \& food & Core & $x$ & 0 & 0 \\
\hline 302 & メモリー & memory & Science \& Technology & Core/Cultural & $\mathrm{x}$ & $\mathrm{x}$ & 0 \\
\hline 303 & メリット & merit & General & Core & 0 & $x$ & 0 \\
\hline 304 & メンバー & member & General & Core & $\mathrm{x}$ & 0 & $\mathrm{x}$ \\
\hline 305 & モード & mode & Multiple & Core & $x$ & $x$ & 0 \\
\hline 306 & モデル & model & Multiple & Core & 0 & 0 & 0 \\
\hline 307 & 그- & you & General (Function word) & Core & $\mathrm{x}$ & $x$ & 0 \\
\hline 308 & ユーザー & user & General & Core & 0 & $\mathrm{x}$ & 0 \\
\hline 309 & ライセンス & license & Economy \& business & Core & 0 & $\mathrm{x}$ & $\mathrm{x}$ \\
\hline 310 & ライフ & life & Personal \& Family Life & Core & 0 & $\mathrm{x}$ & $\mathrm{x}$ \\
\hline 311 & ライブ & live & Media \& Entertainment & Core & $\mathrm{x}$ & $\mathrm{x}$ & 0 \\
\hline 312 & ライン & line & Multiple & Core/Cultural & 0 & 0 & 0 \\
\hline 313 & ラジオ & radio & Science \& Technology & Cultural & $x$ & $\mathrm{x}$ & 0 \\
\hline
\end{tabular}




\begin{tabular}{|c|c|c|c|c|c|c|c|}
\hline 314 & ラブ-love & love & Personal \& Family Life & Core & $x$ & $x$ & 0 \\
\hline 315 & ランド-land & land & General & Core & $x$ & $x$ & 0 \\
\hline 316 & リーグ & league & Sports & Core & $x$ & $x$ & 0 \\
\hline 317 & リサイクル & recycle & Social \& Public Life & Core & 0 & $\mathrm{x}$ & $x$ \\
\hline 318 & リスク & risk & General & Core & 0 & 0 & $\mathrm{x}$ \\
\hline 319 & リスト-list & list & General & Core & $x$ & $x$ & 0 \\
\hline 320 & リチウム & lithium & Material \& substance & Cultural & 0 & $x$ & $x$ \\
\hline 321 & リテラシー & literacy & General & Core & 0 & $\mathrm{x}$ & $\mathrm{x}$ \\
\hline 322 & リハビリテーション & rehabilitation & Medical, Health \& Beauty & Core & 0 & $x$ & $x$ \\
\hline 323 & リンク-link & link & Science \& Technology & Core/Cultural & $\mathrm{x}$ & $\mathrm{x}$ & 0 \\
\hline 324 & リンク-rink & rink & Sports & Cultural & $x$ & $x$ & 0 \\
\hline 325 & ルート-route & route & General & Core & 0 & $\mathrm{x}$ & $x$ \\
\hline 326 & ルール & rule & Social \& Public Life & Core & 0 & 0 & 0 \\
\hline 327 & レシピ & recipe & Dining \& food & Core & $x$ & $x$ & 0 \\
\hline 328 & レストラン & restaurant & Dining \& food & Core-Western & $x$ & 0 & $x$ \\
\hline 329 & レベル & level & General & Core & 0 & 0 & 0 \\
\hline 330 & レンジ & range & Multiple & Core/Cultural & $x$ & $x$ & 0 \\
\hline 331 & レンタル & rental & Economy \& business & Core & $x$ & $x$ & 0 \\
\hline 332 & ローン-loan & loan & Economy \& business & Core & 0 & $x$ & 0 \\
\hline 333 & ログ & $\log$ & Multiple & Core/Cultural & $x$ & $x$ & 0 \\
\hline 334 & ロケット-rocket & rocket & Science \& Technology & Cultural & 0 & $\mathrm{x}$ & $x$ \\
\hline 335 & ロック-rock（音楽） & rock & Media \& Entertainment & Cultural & $x$ & $x$ & 0 \\
\hline 336 & ワード & word & Multiple & Core/Cultural & $\mathrm{x}$ & $\mathrm{x}$ & 0 \\
\hline 337 & ワイン & wine & Dining \& food & Cultural & $\mathrm{x}$ & 0 & $x$ \\
\hline 338 & ワン & one & Numeral \& Math & Core & $x$ & 0 & 0 \\
\hline
\end{tabular}




\section{Appendix B: High-frequency ELWs by Semantic Categories}

\begin{tabular}{|c|c|c|c|c|c|}
\hline 語彙素 (338 Types) & $\begin{array}{l}\text { English (original } \\
\text { form) }\end{array}$ & $\overline{\text { Loan Type }}$ & WP & $\mathrm{BK}$ & IT \\
\hline \multicolumn{6}{|l|}{ Building \& Furniture } \\
\hline アパート & apartment & Core & $x$ & $x$ & 0 \\
\hline テーブル & table & Core-Western & $x$ & 0 & $\mathrm{x}$ \\
\hline ドア & door & Core-Western & $x$ & 0 & 0 \\
\hline トイレ & toilet & Core & $x$ & 0 & 0 \\
\hline ハウス & house & Core & $x$ & 0 & $\mathrm{x}$ \\
\hline ビル-building & building & Core-Western & 0 & 0 & $\mathrm{x}$ \\
\hline ベッド & bed & Core-Western & $x$ & 0 & $\mathrm{x}$ \\
\hline マンション & mansion & Core & 0 & 0 & 0 \\
\hline \multicolumn{6}{|l|}{ Dining \& Food } \\
\hline カレー & curry & Cultural & $x$ & $x$ & 0 \\
\hline ケーキ & cake & Core-Western & $x$ & $x$ & 0 \\
\hline コーヒー & coffee & Cultural & $x$ & 0 & 0 \\
\hline サラダ & salad & Core-Western & $x$ & $x$ & 0 \\
\hline スープ & soup & Core-Western & $x$ & $x$ & 0 \\
\hline ソース-sauce & sauce & Core-Western & $x$ & $x$ & 0 \\
\hline チーズ & cheese & Cultural & $x$ & $x$ & 0 \\
\hline バー & bar & Core-Western & $x$ & $x$ & 0 \\
\hline ビール & beer & Cultural & $x$ & 0 & 0 \\
\hline ミルク & milk & Core & $x$ & $x$ & 0 \\
\hline メニュー & menu & Core & $x$ & 0 & 0 \\
\hline レシピ & recipe & Core & $x$ & $x$ & 0 \\
\hline レストラン & restaurant & Core-Western & $x$ & 0 & $\mathrm{x}$ \\
\hline ワイン & wine & Cultural & $x$ & 0 & $\mathrm{x}$ \\
\hline \multicolumn{6}{|l|}{ Economy \& Business } \\
\hline オークション & auction & Core & $x$ & $x$ & 0 \\
\hline オフィス & office & Core & 0 & $x$ & $\mathrm{x}$ \\
\hline クレーム & claim & Core & $x$ & $x$ & 0 \\
\hline クレジット & credit & Cultural & $x$ & $x$ & 0 \\
\hline コスト & cost & Core & 0 & 0 & $\mathrm{x}$ \\
\hline コンビニ & convenience store & Cultural & $x$ & $x$ & 0 \\
\hline シェア & share & Core/Cultural & 0 & $\mathrm{x}$ & $\mathrm{x}$ \\
\hline ショップ & shop & Core & $x$ & $x$ & 0 \\
\hline ストック-stock & stock & Cultural & 0 & $x$ & $\mathrm{x}$ \\
\hline ディーラー & dealer & Core & $x$ & $x$ & 0 \\
\hline デフレ & deflation & Core & 0 & $x$ & $\mathrm{x}$ \\
\hline ドル & dollar & Cultural & 0 & 0 & 0 \\
\hline バブル & bubble & Core & 0 & $x$ & $\mathrm{x}$ \\
\hline バンク & bank & Core & $x$ & $x$ & 0 \\
\hline ビジネス & business & Core & 0 & 0 & $\mathrm{x}$ \\
\hline ブランド & brand & Core & $x$ & 0 & 0 \\
\hline フロー & flow & Core & 0 & $\mathrm{x}$ & $\mathrm{x}$ \\
\hline ボーナス & bonus & Core & $x$ & $x$ & 0 \\
\hline ホテル & hotel & Core-Western & $x$ & 0 & 0 \\
\hline メーカー & maker & Core & 0 & 0 & 0 \\
\hline ライセンス & license & Core & 0 & $x$ & $\mathrm{x}$ \\
\hline レンタル & rental & Core & $x$ & $x$ & 0 \\
\hline ローン-loan & loan & Core & 0 & $\mathrm{x}$ & 0 \\
\hline \multicolumn{6}{|l|}{ General Meaning } \\
\hline アドバイス & advice & Core & $x$ & $x$ & 0 \\
\hline アンサー & answer & Core & $x$ & $x$ & 0 \\
\hline エラー & error & Core & $x$ & $x$ & 0 \\
\hline オーケー & $\mathrm{OK}$ & Core & $x$ & $x$ & 0 \\
\hline オプション & option & Core & $x$ & $x$ & 0 \\
\hline
\end{tabular}




\begin{tabular}{|c|c|c|c|c|c|}
\hline カット & cut & Core & $x$ & $x$ & 0 \\
\hline カテゴリー & category & Core & $\mathrm{x}$ & $x$ & 0 \\
\hline カラー-color & color & Core & $x$ & $x$ & o \\
\hline キャンセル & cancel & Core & $x$ & $x$ & 0 \\
\hline クエスチョン & question & Core & $x$ & $x$ & 0 \\
\hline グループ & group & Core & 0 & 0 & 0 \\
\hline コピー & copy & Core & $\mathrm{x}$ & $x$ & o \\
\hline コメント & comment & Core & $x$ & $x$ & 0 \\
\hline コントロール & control & Core & $x$ & 0 & o \\
\hline サイズ & size & Core & $x$ & $x$ & 0 \\
\hline シール & seal & Core & $x$ & $x$ & 0 \\
\hline シーン & scene & Core & $\mathrm{x}$ & $x$ & 0 \\
\hline システム & system & Core & 0 & 0 & o \\
\hline ショック & shock & Core & $x$ & $x$ & 0 \\
\hline シリーズ & series & Core & $\mathrm{x}$ & $x$ & 0 \\
\hline スタート & start & Core & $x$ & 0 & 0 \\
\hline スタッフ-staff & staff & Core & $x$ & 0 & $x$ \\
\hline スピード & speed & Core & $x$ & 0 & 0 \\
\hline セキュリティー & security & Core & $x$ & $x$ & 0 \\
\hline タイプ-type & type & Core & $x$ & 0 & 0 \\
\hline タイミング & timing & Core & $x$ & $x$ & 0 \\
\hline タイム-time & time & Core & 0 & 0 & o \\
\hline タオル & towel & Core-Western & $x$ & $x$ & 0 \\
\hline チーム & team & Core & 0 & 0 & o \\
\hline チェック & check & Core & $x$ & 0 & 0 \\
\hline チケット & ticket & Core & $x$ & $x$ & o \\
\hline チャンス & chance & Core & $x$ & 0 & 0 \\
\hline ディテール & detail & Core & $x$ & $x$ & 0 \\
\hline デー & day & Core & $x$ & $x$ & 0 \\
\hline テーマ & theme & Core & 0 & 0 & $\mathrm{x}$ \\
\hline デザイン & design & Core & 0 & 0 & 0 \\
\hline テスト & test & Core & $x$ & 0 & 0 \\
\hline トラブル & trouble & Core & $x$ & $x$ & 0 \\
\hline ニュー & new & Core & $x$ & $x$ & 0 \\
\hline ノウハウ & knowhow & Core & 0 & $x$ & $x$ \\
\hline ノート & note & Core & $x$ & $x$ & 0 \\
\hline バージョン & version & Core & $\mathrm{x}$ & $x$ & o \\
\hline ハイ-high & high & Core & $x$ & $x$ & 0 \\
\hline パターン & pattern & Core & $x$ & 0 & $x$ \\
\hline バランス & balance & Core & 0 & 0 & 0 \\
\hline ピーク & peak & Core & 0 & $x$ & $x$ \\
\hline プラン & plan & Core & 0 & $x$ & $x$ \\
\hline フル & full & Core & 0 & $x$ & o \\
\hline プロ-pro & pro & Core & $x$ & 0 & 0 \\
\hline プロジェクト & project & Core & 0 & 0 & $x$ \\
\hline プロセス & process & Core & 0 & 0 & $x$ \\
\hline ベスト-best & best & Core & $x$ & $x$ & 0 \\
\hline マーク & mark & Core & $x$ & $x$ & 0 \\
\hline マネージメント & management & Core & 0 & 0 & $x$ \\
\hline マン & man & Core & $x$ & 0 & 0 \\
\hline ミス-mistake & mistake & Core & $x$ & $x$ & 0 \\
\hline ミニ & $\operatorname{mini}$ & Core & $x$ & $x$ & 0 \\
\hline メーン & main & Core & $x$ & $x$ & 0 \\
\hline メリット & merit & Core & 0 & $x$ & o \\
\hline メンバー & member & Core & $x$ & 0 & $x$ \\
\hline ユーザー & user & Core & 0 & $x$ & o \\
\hline ランド-land & land & Core & $x$ & $x$ & 0 \\
\hline リスク & risk & Core & 0 & 0 & $x$ \\
\hline
\end{tabular}




\begin{tabular}{|c|c|c|c|c|c|}
\hline リスト-list & list & Core & $x$ & $x$ & 0 \\
\hline リテラシー & literacy & Core & 0 & $x$ & $x$ \\
\hline ルート-route & route & Core & 0 & $x$ & $x$ \\
\hline レベル & level & Core & 0 & 0 & 0 \\
\hline アウト & out & Core & $x$ & $x$ & 0 \\
\hline アップ & up & Core & 0 & 0 & 0 \\
\hline アンド & and & Core & 0 & 0 & 0 \\
\hline イン-in & in & Core & 0 & 0 & 0 \\
\hline オア & or & Core & $x$ & $x$ & 0 \\
\hline オフ & off & Core & $x$ & $x$ & 0 \\
\hline オブ & of & Core & 0 & 0 & 0 \\
\hline オン & on & Core & 0 & 0 & 0 \\
\hline ザ & the & Core & $x$ & 0 & 0 \\
\hline ダウン & down & Core & $x$ & $x$ & 0 \\
\hline ツー-to & to & Core & $x$ & $x$ & 0 \\
\hline ノー & no & Core & $x$ & $x$ & 0 \\
\hline バイ-by & by & Core & $x$ & $x$ & 0 \\
\hline バック & back & Core & $x$ & $x$ & 0 \\
\hline ファースト-first & first & Core & $x$ & $x$ & 0 \\
\hline マイ & my & Core & $x$ & $x$ & 0 \\
\hline ミ--me & me & Core & $x$ & $x$ & 0 \\
\hline 그- & you & Core & $x$ & $x$ & 0 \\
\hline \multicolumn{6}{|c|}{ Material \& Substance } \\
\hline イオン-Ion & ion & Cultural & $x$ & 0 & $x$ \\
\hline ウラン & uranium & Cultural & 0 & $x$ & $x$ \\
\hline ガス & gas & Core & 0 & 0 & 0 \\
\hline ガソリン & gasoline & Cultural & $x$ & $x$ & 0 \\
\hline ガラス & glass & Core & $x$ & 0 & 0 \\
\hline ゴム & gum & Cultural & $x$ & $x$ & 0 \\
\hline コンクリート & concrete & Cultural & 0 & $x$ & $x$ \\
\hline タバコ & Tabaco & Cultural & $x$ & 0 & 0 \\
\hline ビタミン & vitamin & Cultural & $x$ & $x$ & 0 \\
\hline プラスチック & plastic & Cultural & 0 & $\mathrm{x}$ & $x$ \\
\hline リチウム & lithium & Cultural & 0 & $x$ & $x$ \\
\hline \multicolumn{6}{|c|}{ Measurements \& Units } \\
\hline カロリー & calorie & Cultural & $\mathrm{x}$ & $x$ & 0 \\
\hline キロ & kilo & Cultural & $x$ & 0 & 0 \\
\hline キログラム & kilogram & Cultural & 0 & $x$ & 0 \\
\hline キロメートル & kilometer & Cultural & 0 & $x$ & 0 \\
\hline グラム & gram & Cultural & $\mathrm{x}$ & 0 & 0 \\
\hline センチ & centimeter & Cultural & $\mathrm{x}$ & 0 & 0 \\
\hline センチメートル & centimeter & Cultural & $x$ & 0 & 0 \\
\hline トン & ton & Cultural & 0 & $\mathrm{x}$ & $x$ \\
\hline パーセント & percent & Cultural & 0 & 0 & 0 \\
\hline ヘクタール & hectare & Cultural & 0 & $\mathrm{x}$ & $x$ \\
\hline ポイント & point & Core & 0 & 0 & 0 \\
\hline メートル & meter & Cultural & 0 & 0 & 0 \\
\hline メガバイト & mega bite & Cultural & $x$ & $x$ & 0 \\
\hline \multicolumn{6}{|c|}{ Media \& Entertainment } \\
\hline アニメ & anime & Cultural & $x$ & $x$ & 0 \\
\hline ギター & guitar & Cultural & $x$ & $x$ & 0 \\
\hline ゲーム & game & Core & $x$ & 0 & 0 \\
\hline ショー & show & Core & $\mathrm{x}$ & $x$ & 0 \\
\hline タレント & talent & Core & $x$ & $x$ & 0 \\
\hline チャンネル & channel & Cultural & 0 & $x$ & 0 \\
\hline ッアー & tour & Core & $x$ & $x$ & 0 \\
\hline ドラマ & drama & Core & $x$ & $x$ & 0 \\
\hline ニュース & news & Core & $x$ & 0 & 0 \\
\hline
\end{tabular}




\begin{tabular}{|c|c|c|c|c|c|}
\hline バンド-band & band & Core-Western & $\mathrm{x}$ & $\mathrm{x}$ & 0 \\
\hline ピアノ & piano & Cultural & $\mathrm{x}$ & $x$ & 0 \\
\hline ファン-fan（熱狂者） & fan & Core & $x$ & $x$ & 0 \\
\hline マス & mass & Core & 0 & $x$ & $x$ \\
\hline メディア & media & Core & 0 & 0 & 0 \\
\hline ライブ & live & Core & $x$ & $x$ & 0 \\
\hline ロック-rock（音楽） & rock & Cultural & $x$ & $x$ & 0 \\
\hline \multicolumn{6}{|c|}{ Medical, Health, and Beauty } \\
\hline アレルギー & allergy & Core & $x$ & $x$ & 0 \\
\hline ウイルス & virus & Cultural & $\mathrm{x}$ & $\mathrm{x}$ & 0 \\
\hline ケア & care & Core & 0 & 0 & $x$ \\
\hline シャンプー & shampoo & Core-Western & $x$ & $x$ & 0 \\
\hline ストレス & stress & Core & $x$ & 0 & 0 \\
\hline ダイエット & diet & Core & $x$ & $x$ & 0 \\
\hline ホルモン & hormone & Cultural & $x$ & 0 & $x$ \\
\hline メーク & make & Core & $\mathrm{x}$ & $\mathrm{x}$ & 0 \\
\hline リハビリテーション & rehabilitation & Core & 0 & $x$ & $\mathrm{x}$ \\
\hline \multicolumn{6}{|l|}{ Multiple Meanings } \\
\hline アクセス & access & Core/Cultural & 0 & $x$ & 0 \\
\hline アドレス & address & Core/Cultural & $x$ & $x$ & 0 \\
\hline アルバム & album & Cultural & $\mathrm{x}$ & $x$ & 0 \\
\hline イメージ & image & Core/Cultural & 0 & 0 & 0 \\
\hline ウインドー & window & Core/Cultural & $x$ & $x$ & 0 \\
\hline エアー & air & Core/Cultural & $x$ & $x$ & 0 \\
\hline エネルギー & energy & Core & 0 & 0 & $x$ \\
\hline オイル & oil & Core & $x$ & $x$ & 0 \\
\hline カード & card & Core/Cultural & $x$ & 0 & 0 \\
\hline カップ & cup & Core/Cultural & $\mathrm{x}$ & $\mathrm{x}$ & 0 \\
\hline カバー & cover & Core & $\mathrm{x}$ & $x$ & 0 \\
\hline キー & key & Core/Cultural & $x$ & 0 & 0 \\
\hline キャラ & character & Core & $x$ & $x$ & 0 \\
\hline クラス & class & Core & $x$ & 0 & 0 \\
\hline クラブ & club & Core/Cultural & 0 & 0 & 0 \\
\hline クリア & clear & Core & $x$ & $x$ & 0 \\
\hline クリーム & cream & Cultural & $x$ & $x$ & 0 \\
\hline グリーン & green & Core & 0 & $x$ & $x$ \\
\hline ケース & case & Core & 0 & 0 & 0 \\
\hline コース & course & Core & $x$ & 0 & 0 \\
\hline コード-code & code & Core/Cultural & $x$ & $x$ & 0 \\
\hline サービス & service & Core & 0 & 0 & 0 \\
\hline サイクル & cycle & Core/Cultural & 0 & $x$ & $\mathrm{x}$ \\
\hline シート-sheet & sheet & Core/Cultural & 0 & $x$ & 0 \\
\hline スーパー-super & super & Core/Cultural & $x$ & $\mathrm{x}$ & 0 \\
\hline スタイル & style & Core & $x$ & 0 & 0 \\
\hline セット & set & Core & $\mathrm{x}$ & $x$ & 0 \\
\hline センター & center & Core & 0 & 0 & 0 \\
\hline ソフト & soft & Core/Cultural & 0 & 0 & 0 \\
\hline タイトル & title & Core & $x$ & $x$ & 0 \\
\hline ツール & tool & Core/Cultural & $\mathrm{x}$ & $x$ & 0 \\
\hline データ & data & Core/Cultural & 0 & 0 & 0 \\
\hline テープ & tape & Core/Cultural & $x$ & $x$ & 0 \\
\hline トップ & top & Core & $x$ & 0 & 0 \\
\hline ネットワーク & network & Core/Cultural & 0 & 0 & $x$ \\
\hline ハード & hard & Core/Cultural & 0 & $x$ & $x$ \\
\hline パート-part & part & Core & 0 & $x$ & 0 \\
\hline パック-pack & pack & Core & $x$ & $x$ & 0 \\
\hline バリア & barrier & Core & 0 & $x$ & $\mathrm{x}$ \\
\hline パワー & power & Core & $\mathrm{x}$ & $x$ & 0 \\
\hline
\end{tabular}




\begin{tabular}{|c|c|c|c|c|c|}
\hline ファイル & file & Cultural & $x$ & 0 & 0 \\
\hline フォルダー & folder & Cultural & $x$ & $x$ & 0 \\
\hline フリー-free & free & Core & 0 & $x$ & 0 \\
\hline ブルー & blue & Core & $x$ & $x$ & 0 \\
\hline プレー & play & Core/Cultural & $x$ & $x$ & 0 \\
\hline プレーヤー & player & Core/Cultural & $x$ & $x$ & 0 \\
\hline プログラム & program & Core/Cultural & 0 & 0 & 0 \\
\hline ブロック-block & block & Core/Cultural & 0 & $x$ & $x$ \\
\hline ページ & page & Core/Cultural & 0 & 0 & 0 \\
\hline ベース-base & base & Core/Cultural & 0 & 0 & $\mathrm{x}$ \\
\hline ホーム-home & home & Core/Cultural & 0 & 0 & 0 \\
\hline ボタン & button & Cultural & $x$ & 0 & 0 \\
\hline ボックス & box & Core & $x$ & $x$ & 0 \\
\hline マニュアル & manual & Core/Cultural & 0 & $x$ & $x$ \\
\hline モード & mode & Core & $x$ & $x$ & 0 \\
\hline モデル & model & Core & 0 & 0 & 0 \\
\hline ライン & line & Core/Cultural & 0 & 0 & 0 \\
\hline レンジ & range & Core/Cultural & $x$ & $x$ & 0 \\
\hline ログ & $\log$ & Core/Cultural & $x$ & $x$ & 0 \\
\hline ワード & word & Core/Cultural & $x$ & $x$ & 0 \\
\hline \multicolumn{6}{|l|}{ Numeral \& Math } \\
\hline エイト & eight & Core & 0 & $x$ & $x$ \\
\hline ゼロ & zero & Core & 0 & $x$ & $x$ \\
\hline ツー-two & two & Core & $x$ & $x$ & 0 \\
\hline ナンバー & number & Core & $x$ & $x$ & 0 \\
\hline プラス & plus & Core & $x$ & $x$ & 0 \\
\hline マイナス & minus & Core & $x$ & 0 & 0 \\
\hline ワン & one & Core & $x$ & 0 & 0 \\
\hline \multicolumn{6}{|c|}{ Personal \& Family Life } \\
\hline キス & kiss & Core & $x$ & $x$ & 0 \\
\hline シャツ & shirt & Core-Western & $x$ & $x$ & 0 \\
\hline スーツ & suit & Cultural & $\mathrm{x}$ & $\mathrm{x}$ & 0 \\
\hline セックス & sex & Core & $x$ & $x$ & 0 \\
\hline デート & date & Core & $x$ & $x$ & 0 \\
\hline パンツ & pants & Core-Western & $x$ & $\mathrm{x}$ & 0 \\
\hline ペット-pet & pet & Core & $x$ & $x$ & 0 \\
\hline ベビー & baby & Core & $x$ & $x$ & 0 \\
\hline ママ & mama & Core & $x$ & 0 & 0 \\
\hline ライフ & life & Core & 0 & $x$ & $\mathrm{x}$ \\
\hline ラブ-love & love & Core & $x$ & $x$ & 0 \\
\hline \multicolumn{6}{|c|}{ Science \& Technology } \\
\hline アナログ & analog & Cultural & 0 & $x$ & $x$ \\
\hline インストール & install & Cultural & $\mathrm{x}$ & $x$ & 0 \\
\hline インターネット & internet & Cultural & 0 & 0 & 0 \\
\hline ウィン-win- & win & Cultural & $x$ & $x$ & 0 \\
\hline ウェブ & web & Cultural & $x$ & $\mathrm{x}$ & 0 \\
\hline エアコン & air conditioner & Cultural & $x$ & $x$ & 0 \\
\hline エクセル & excel & Cultural & $x$ & $x$ & 0 \\
\hline カメラ & camera & Cultural & $\mathrm{x}$ & 0 & 0 \\
\hline クリック & click & Cultural & $x$ & 0 & 0 \\
\hline ケーブル & cable & Cultural & 0 & $x$ & 0 \\
\hline コンテンツ & contents & Core/Cultural & 0 & $x$ & $\mathrm{x}$ \\
\hline コンピューター & computer & Cultural & 0 & 0 & 0 \\
\hline サーバー & server & Cultural & $\mathrm{x}$ & $x$ & 0 \\
\hline サイエンス & science & Core & 0 & $x$ & $x$ \\
\hline サイト & site & Cultural & 0 & $x$ & 0 \\
\hline セル-cell & cell & Cultural & $x$ & $x$ & 0 \\
\hline ダウンロード & download & Cultural & $x$ & $x$ & 0 \\
\hline
\end{tabular}




\begin{tabular}{|c|c|c|c|c|c|}
\hline ディスク & disk & Cultural & $x$ & $x$ & 0 \\
\hline データーベース & database & Cultural & 0 & $x$ & $\mathrm{x}$ \\
\hline デジカメ & digital camera & Cultural & $x$ & $x$ & 0 \\
\hline デジタル & digital & Cultural & 0 & $\mathrm{x}$ & 0 \\
\hline デスクトップ & desktop & Cultural & $x$ & $x$ & 0 \\
\hline テレビ & television & Cultural & 0 & 0 & 0 \\
\hline テレビジョン & television & Cultural & 0 & $x$ & $x$ \\
\hline ネット & net & Cultural & 0 & $x$ & 0 \\
\hline バイオマス & biomass & Cultural & 0 & $x$ & $x$ \\
\hline ハイテク & high-tech & Cultural & 0 & $x$ & $x$ \\
\hline パスワード & password & Core & $x$ & $\mathrm{x}$ & 0 \\
\hline パソコン & personal computer & Cultural & 0 & 0 & 0 \\
\hline バッテリー & battery & Cultural & $x$ & $x$ & 0 \\
\hline ビデオ & video & Cultural & 0 & $x$ & 0 \\
\hline プリンター & printer & Cultural & $x$ & $\mathrm{x}$ & 0 \\
\hline プロバイダー & provider & Cultural & $x$ & $x$ & 0 \\
\hline マウス & mouse & Cultural & $x$ & $x$ & 0 \\
\hline ミサイル & missile & Cultural & 0 & $x$ & $x$ \\
\hline メール-mail & mail & Cultural & $x$ & 0 & 0 \\
\hline メモリー & memory & Core/Cultural & $x$ & $x$ & 0 \\
\hline ラジオ & radio & Cultural & $\mathrm{x}$ & $x$ & 0 \\
\hline リンク-link & link & Core/Cultural & $\mathrm{x}$ & $\mathrm{x}$ & 0 \\
\hline ロケット-rocket & rocket & Cultural & 0 & $x$ & $x$ \\
\hline \multicolumn{6}{|l|}{ Social \& Public Life } \\
\hline イスラム & Islam & Cultural & $x$ & 0 & $x$ \\
\hline イニシアチブ & initiative & Core & 0 & $x$ & $x$ \\
\hline イベント & event & Core & 0 & $x$ & $\mathrm{x}$ \\
\hline インフラ & infrastructure & Core & 0 & $\mathrm{x}$ & $x$ \\
\hline エリア & area & Core & 0 & $\mathrm{x}$ & $x$ \\
\hline ガイド & guide & Core & 0 & $x$ & $\mathrm{x}$ \\
\hline ガイドライン & guideline & Core & 0 & $x$ & $x$ \\
\hline クリスマス & Christmas & Cultural & $x$ & $x$ & 0 \\
\hline グローバル & global & Core & 0 & $x$ & $x$ \\
\hline コミュニケーション & communication & Core & 0 & 0 & $x$ \\
\hline コミュニティー & community & Core & 0 & $x$ & $x$ \\
\hline サミット & summit & Cultural & 0 & $x$ & $x$ \\
\hline シンポジウム & symposium & Core & 0 & $\mathrm{x}$ & $x$ \\
\hline セミナー & seminar & Core & 0 & $x$ & $\mathrm{x}$ \\
\hline チャリティー & charity & Core & 0 & $x$ & $x$ \\
\hline テロ & terrorism & Core & 0 & $x$ & $x$ \\
\hline ニーズ & needs & Core & 0 & 0 & $x$ \\
\hline パートナーシップ & partnership & Core & 0 & $x$ & $x$ \\
\hline パトロール & patrol & Core & 0 & $\mathrm{x}$ & $x$ \\
\hline パンフレット & pamphlet & Core & 0 & $x$ & $x$ \\
\hline フォーラム & forum & Core & 0 & $x$ & $x$ \\
\hline プレゼント & present & Core & $x$ & $\mathrm{x}$ & 0 \\
\hline ボランティア & volunteer & Core & 0 & $x$ & $x$ \\
\hline マップ & map & Core & 0 & $x$ & $x$ \\
\hline マナー & manner & Core & $\mathrm{x}$ & $x$ & o \\
\hline メッセージ & message & Core & $x$ & 0 & 0 \\
\hline リサイクル & recycle & Core & 0 & $x$ & $x$ \\
\hline ルール & rule & Core & 0 & 0 & 0 \\
\hline \multicolumn{6}{|l|}{ Sports } \\
\hline サッカー & soccer & Cultural & $x$ & $x$ & 0 \\
\hline スポーツ & sports & Core & 0 & 0 & 0 \\
\hline ボール-ball & ball & Core & $x$ & 0 & 0 \\
\hline リーグ & league & Core & $x$ & $x$ & 0 \\
\hline リンク-rink & rink & Cultural & $x$ & $x$ & 0 \\
\hline
\end{tabular}




\begin{tabular}{|l|l|l|l|l|l|}
\hline Vehicles & engine & Cultural & $\mathrm{x}$ & $\mathrm{x}$ & 0 \\
\hline エンジン & car & Cultural & $\mathrm{x}$ & $\mathrm{x}$ & 0 \\
\hline カー & tire & Cultural & $\mathrm{x}$ & $\mathrm{x}$ & 0 \\
\hline タイヤ & driver & Cultural & $\mathrm{x}$ & $\mathrm{x}$ & 0 \\
\hline ドライバー & drive & Cultural & $\mathrm{x}$ & $\mathrm{x}$ & 0 \\
\hline ドライブ & bike & Cultural & $\mathrm{x}$ & $\mathrm{x}$ & 0 \\
\hline バイク & bus & Cultural & 0 & 0 & 0 \\
\hline バス-bus & helicopter & Cultural & 0 & $\mathrm{x}$ & $\mathrm{x}$ \\
\hline ヘリコプター & & & & \\
\hline
\end{tabular}

